
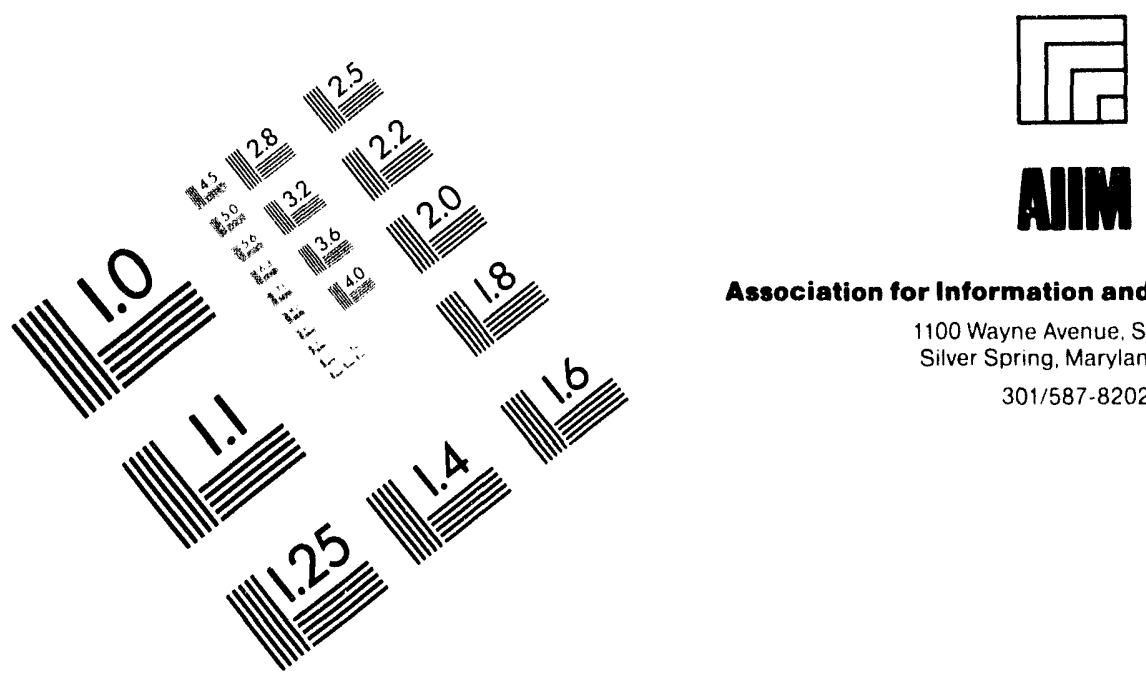

Association for Information and Image Management

1100 Wayne Avenue. Suite 1100

Silver Spring, Maryland 20910

$301 / 587-8202$

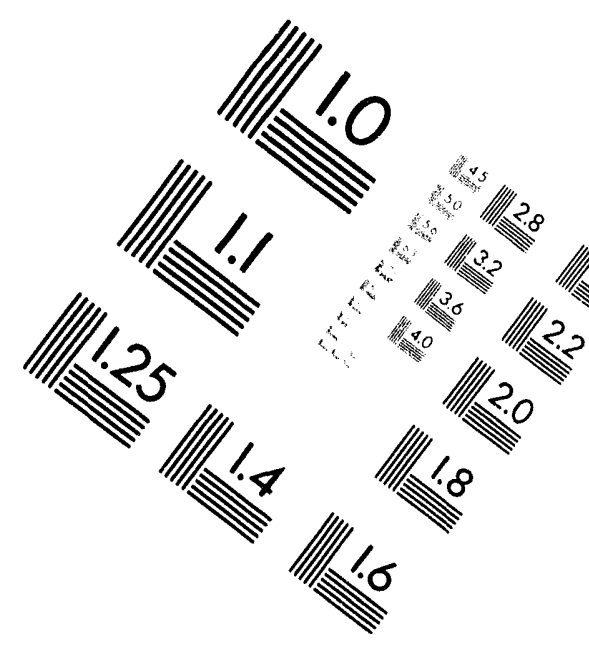

\title{
Centimeter
}

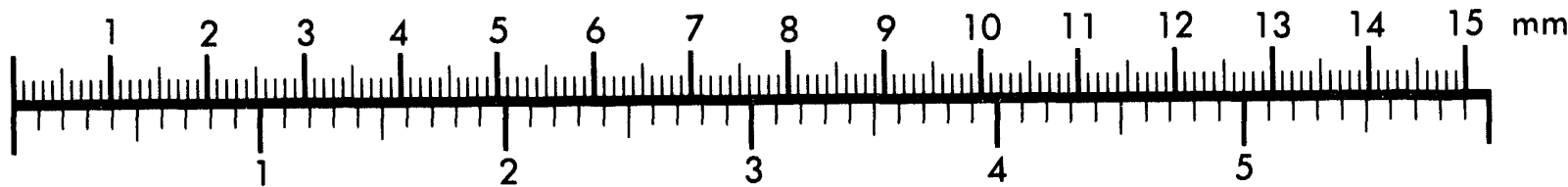

Inches
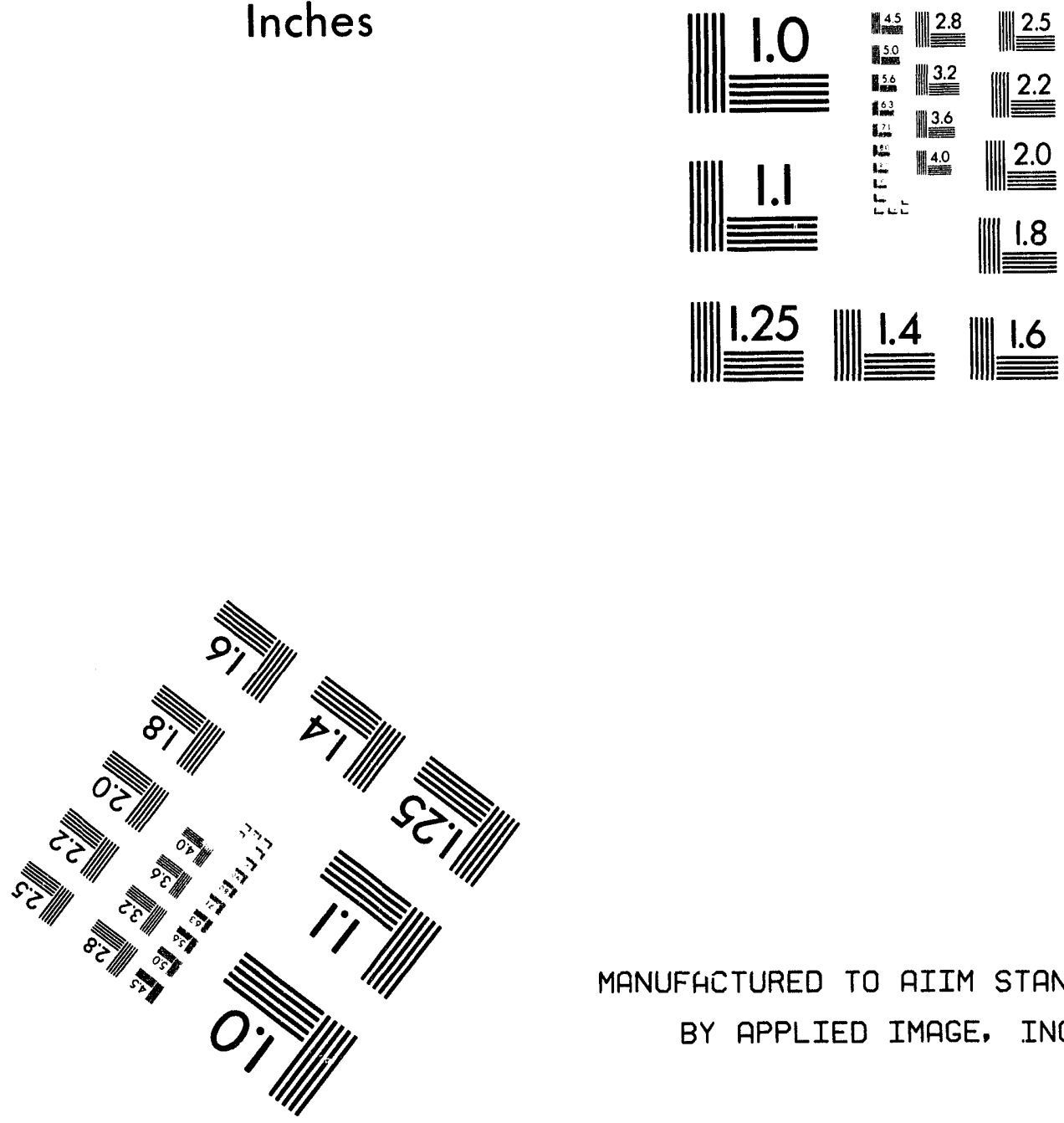

MANUFACTURED TO AIIM STANDARDS

BY APPLIED IMAGE, INC.

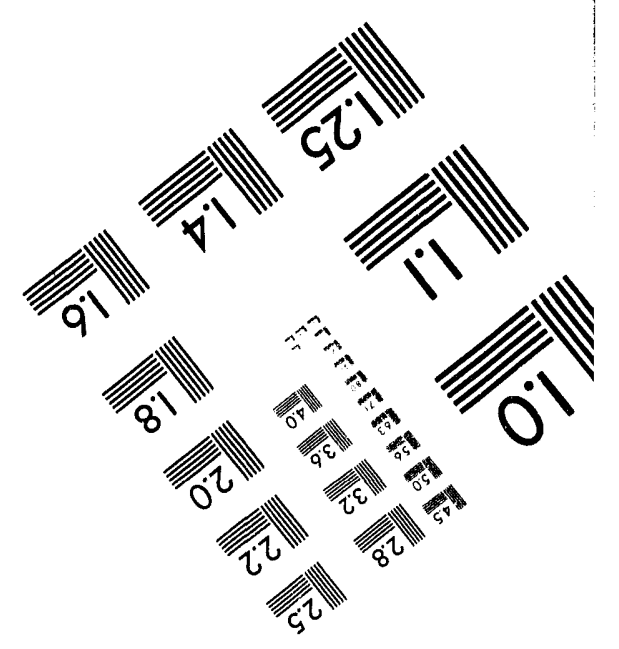



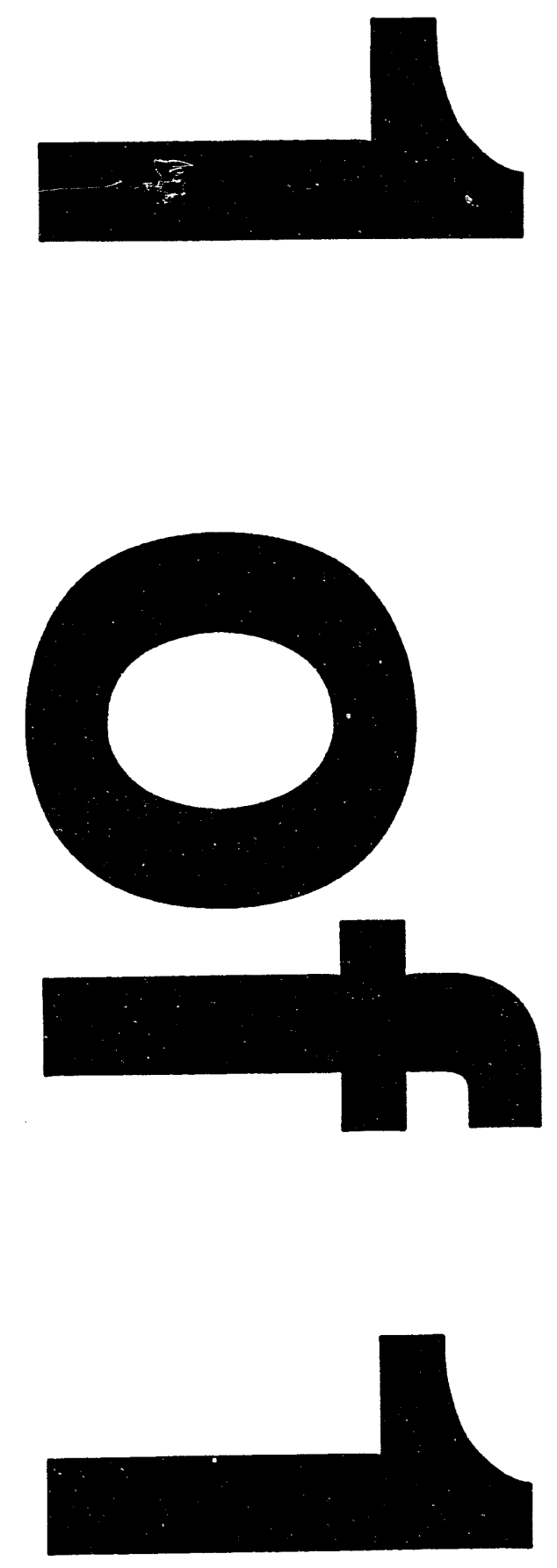
DOE/RL-93-79

Rev. 0

UC-630

\section{Limited Field Investigation Report for the 100-KR-4 Operable Unit}

Date Published
July 1994

United States

Department of Energy

P.O. Box 550

Richland, Wastinigten 99352 


\section{EXECUTIVE SUMMARY}

This limited field investigation (LFI) was conducted to optimize the use of interim remedial measures (IRM) for expediting clean up while maintaining a technically sound and cost-effective program. The 100-KR-4 Operable Unit is one of four operable units associated with the $100 \mathrm{~K}$ Area. Operable units KR-1, KR-2 and KR-3 address contaminant sources while $100-\mathrm{KR}-4$ addresses contamination present in the underlying groundwater. The IRM decision process for groundwater operable units is based on three aspects:

1) Is the concentration greater than Hanford background?

2) Does the concentration present a medium or high human-health risk?

3) Does the concentration exceed an ecologically based applicable, relevant and appropriate requirements (ARAR) or present an environmental hazard quotient $>1$ ?

The primary methods of investigation used during this LFI were the installation of monitoring wells and sampling of groundwater. The samples collected from the groundwater and soils were submitted for laboratory analysis. Boreholes were surveyed for radiological contamination using downhole geophysical techniques to further delineate the location and degree of contamination. All soil samples were screened to ascertain the presence of volatile organic compounds and radionuclides. Analytical data were subjected to validation; all first round and a minimum of $10 \%$ of subsequent round data were validated.

The analytical data were screened to identify contaminants of concern. This screening method eliminated from further consideration, constituents that were below risk based concentration values and ARAR or could not be distinguished from background.

A human health qualitative risk assessment (QRA) was performed using conservative (highest representative contaminant concentrations) analyses. The QRA analysis indicates that there is a medium risk for the high frequency-of-use scenario and a low risk associated with the low frequency-of-use scenario due to carcinogens. Noncarcinogenic risk exhibits a hazard quotient of $<1$ in the occasional-use scenario and $>1$ in the frequent-use scenario.

A parallel ecological QRA was performed using a subset of the data used in the human health QRA. This assessment used conservative data from wells located closest to the Columbia River. Several nonradioactive constituents were identified as posing an acute or chronic risk to aquatic organisms. Carbon-14 was the only radionuclide calculated to result in a potential exposure of more than $1 \mathrm{rad} / \mathrm{d}$. Based on this method, groundwater contaminants exceeding either acute or chronic lowest obscrvabie effect levels are chromium, iron, lead, silver, and zinc.

- Continuation along the IRM pathway is recommended for the 100-KR-4 Operable Unit based on the risk to the ecosystem. 


\section{ACRONYMS}

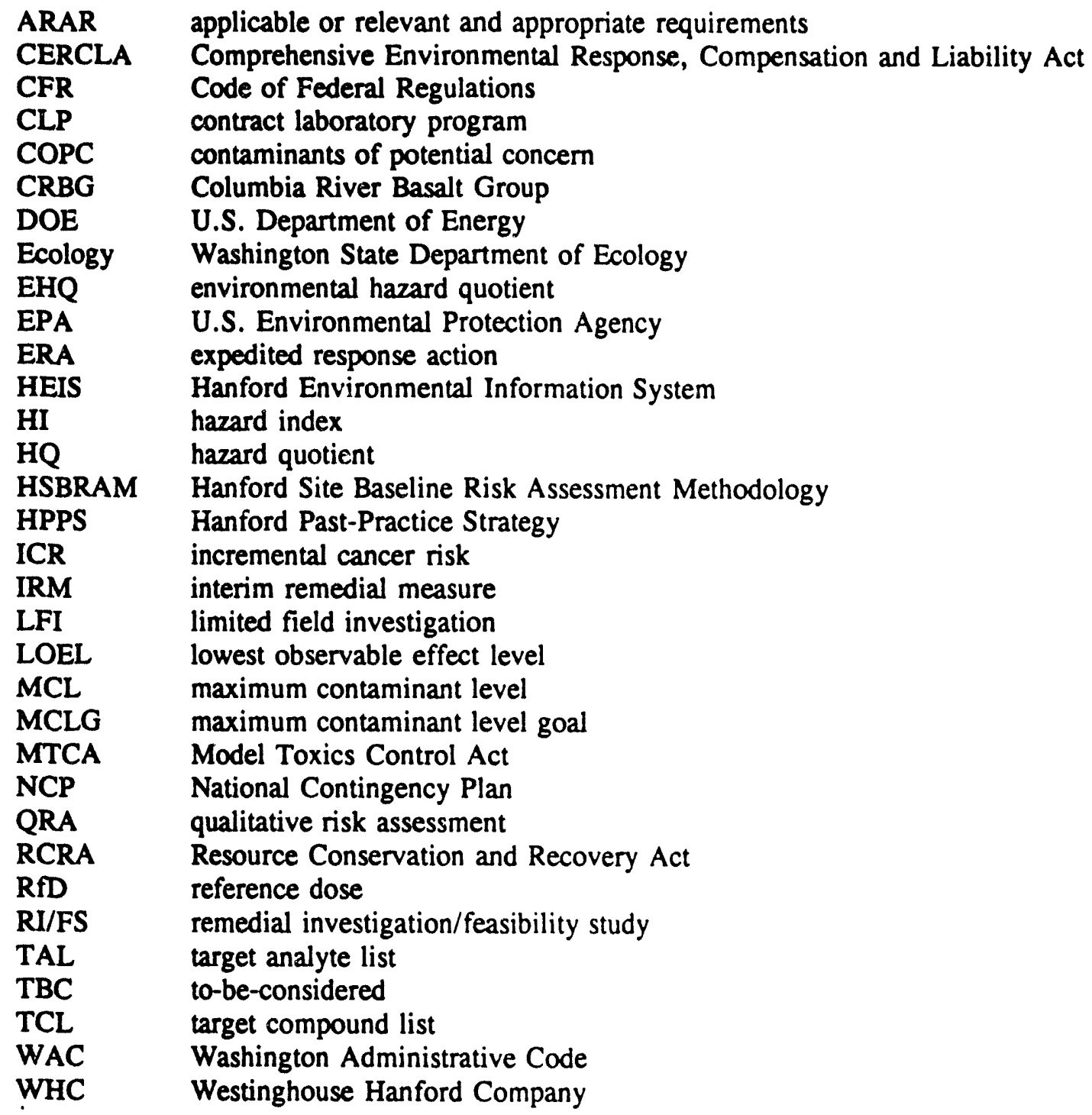




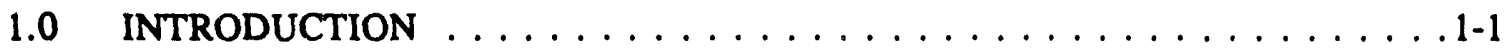

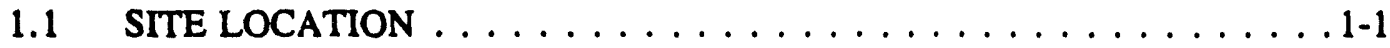

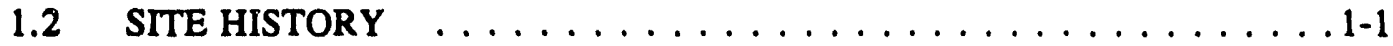

1.3 LIMITED FIELD INVESTIGATION STRATEGY . . . . . . . . . 1-2

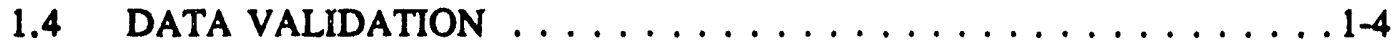

2.0 INVESTIGATION ACTIVITIES AND RESULTS $\ldots \ldots \ldots \ldots \ldots \ldots \ldots$

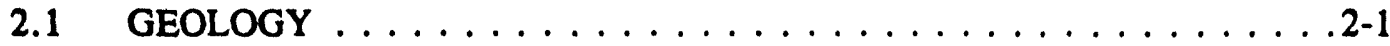

2.1.1 Topography ...................... . . . .

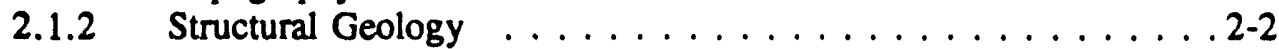

2.1.3 Stratigraphy . . . . . . . . . . . . . . . 2-2

2.1.4 Hanford Formation/Ringold Formation Contact . . . . . . . . 2-3

2.1.5 Physical Properties . . . . . . . . . . . . . . 2-3

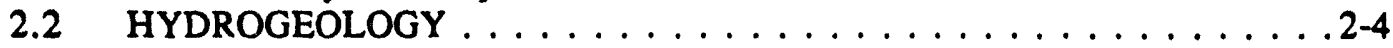

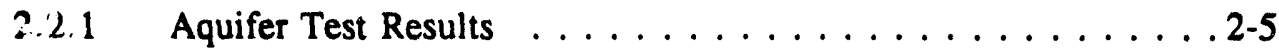

2.3 GEUPHYSICAL LOGGING $\ldots \ldots \ldots \ldots \ldots \ldots \ldots \ldots \ldots$

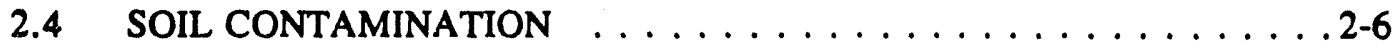

2.5 GROUNDWATER CONTAMINATION . . . . . . . . . . . . 2-6

2.5.1 Determination of Contaminants of Concern . . . . . . . 2-7

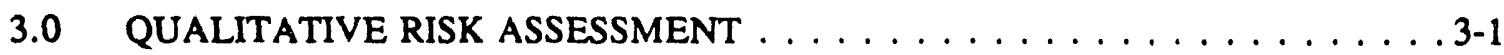

3.1 SUMMARY OF DATA USED $\ldots \ldots \ldots \ldots \ldots \ldots \ldots \ldots \ldots \ldots$

3.2 HUMAN HEALTH EVALUATION $\ldots \ldots \ldots \ldots \ldots \ldots \ldots \ldots \ldots$

3.2.1 Overview of Human Health Evaluation Process . . . . . . . . . 3-1

3.2.2 Summary and Conclusions . . . . . . . . . . . 3-2

3.2.3 Risk From Background Levels of COPC . . . . . . . . . . . . 3-3

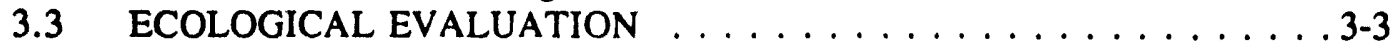

3.3.1 Overview of Ecological Evaluation Process . . . . . . . . 3-3

3.3.2 Summary and Conclusions . . . . . . . . . . . . . 3-4

3.4 SUMMARY OF THE UNCERTAINTY IN THE QRA . . . . . . . . 3-5

3.4.1 Uncertainty in the QRA Data . . . . . . . . . . . . 3-5

3.4.2 Uncertainty in the Human Health Evaluation . . . . . . . . 3-6

3.4.3 Uncertainty in the Ecological Evaluation . . . . . . . . . 3-7

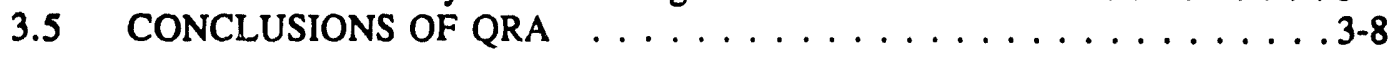

4.0 CONTAMINANTS OF POTENTIAL CONCERN IN THE GROUNDWATER . . 4-1

4.1 CONTAMINANTS OF POTENTIAL CONCERN . . . . . . . . . . 4-1

4.1.1 Chromium . . . . . . . . . . . . . . . 4-1

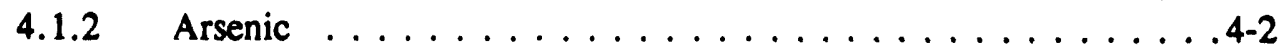

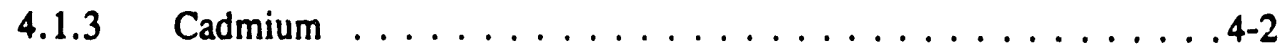

4.1 .4 Manganese . . . . . . . . . . . . . . . 4-2

4.1.5 Nitrate/Nitrite . . . . . . . . . . . . . .4-2

4.1.6 Trichloroethene ..................4-2

4.1.7 Chloroform . . . . . . . . . . . . . . . . 4-3 


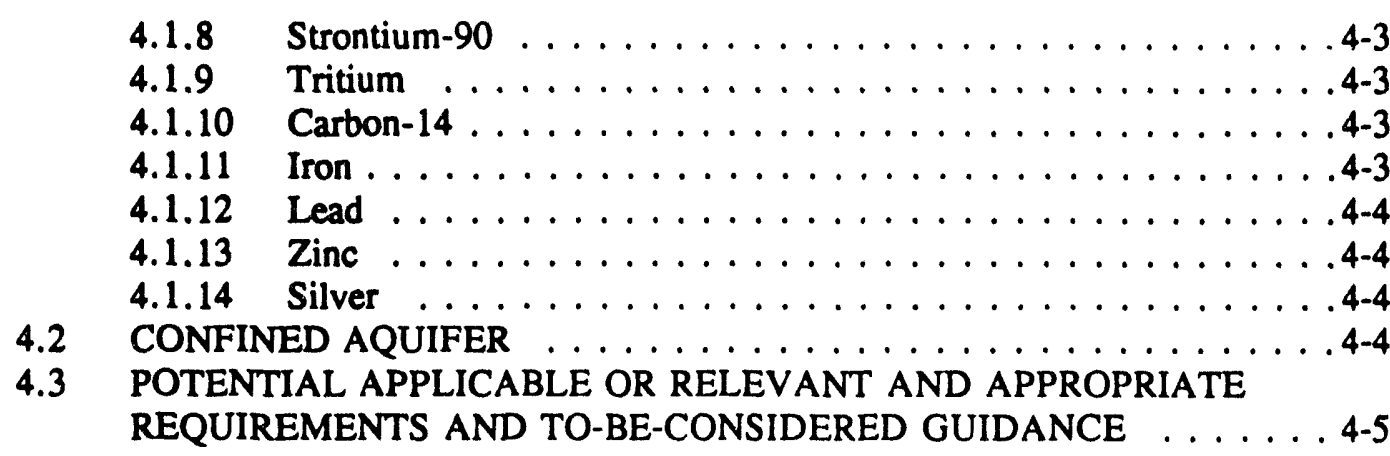

5.0 CONCLUSIONS AND RECOMMENDATIONS $\ldots \ldots \ldots \ldots \ldots \ldots \ldots$

5.1 CONCLUSIONS . . . . . . . . . . . . . . . . 5-1

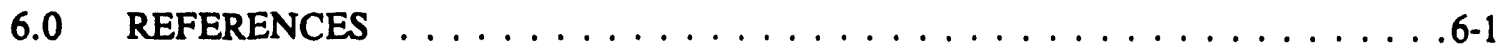

APPENDIX:
A - MAXIMUM CONCENTRATION SCREENING LOGIC $\ldots \ldots \ldots \ldots \ldots \ldots$ A-1

FIGURES:

1-1 100 Area Reactor Locations . . . . . . . . . . . . . . . . . . . . . . . . . 1F-1

1-2 100-KR-4 Operable Unit and Well Locations . . . . . . . . . . . . . . . 1F-2

1-3 Waste Sites in the $100 \mathrm{~K}$ Area . . . . . . . . . . . . . . . . 1F-3

1-4 Hanford Past-Practice Strategy Process . . . . . . . . . . . . . . . 1F-4

2-1 Stratigraphic Column of the 100-KR-4 Operable Unit . . . . . . . . . . 2F-1

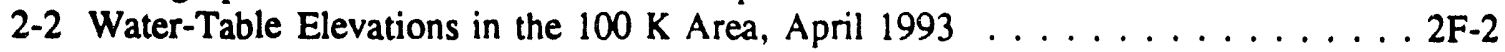

2-3 Water-Table Elevations in the $100 \mathrm{~K}$ Area, June $1993 \ldots \ldots \ldots \ldots$. . . . . . . 2F-3

2-4 Network of Wells Sampled for the 100-KR-4 Investigation . . . . . . . . 2F-4

2-5 Decision Tree for Determining Contaminants of Concern . . . . . . . . . . . 2F-5

4-1 Chromium Concentrations in the $100 \mathrm{~K}$ Area Groundwater . . . . . . . . . . . . 4F-1

4-2 Arsenic Concentrations in the $100 \mathrm{~K}$ Area Groundwater . . . . . . . . . . . 4F-2

4-3 Tritium Concentrations in the $100 \mathrm{~K}$ Area Groundwater . . . . . . . . . . . . 4F-3

4-4 Carbon-14 Concentrations in the $100 \mathrm{~K}$ Area Groundwater . . . . . . . . . . . . 4F-4

TABLES:

2-1 Inventory of New Wells used in $100-\mathrm{KR}-4 \mathrm{LFI} \ldots \ldots \ldots \ldots \ldots$. . . . . . . . . . .

2-2 Wells Sampled During 100-KR-4 LFI . . . . . . . . . . . . . . . . 2T-2

2-3 Summary of Aquifer Test Data, 100-KR-4 Operable Unit . . . . . . . . . . . . . . 2T-3

2-4 Range of Soil Chemical and Radiological Analyses . . . . . . . . . . . . . . 2T-4

2-5 K Area LFI Volatile Organic Analyte . . . . . . . . . . . . . . . 2T-5

2-6 K Area LFI Semi-Volatile Data Summary . . . . . . . . . . . . . . . 2T-6a 
DOE/RL-93-79, Rev. 0

CONTENTS (cont)

TABLES (cont):

2-7 K Area LFI Pesticide Data Summary . . . . . . . . . . . . . . . . . . 2T-7

2-8 K Area LFI Radioisotopes Data Summary . . . . . . . . . . . . . . . . 2T-8

2-9 K Area LFI Wet Chemistry and Anions Data Summary . . . . . . . . . . . . . 2T-9

2-10 K Area LFI Catior Data Summary . . . . . . . . . . . . . . . . . . 2T-10

2-11 K Area LFI Near-River Volatile Organic Analyte Data Summary . . . . . . . . 2T-11

2-12 K Area LFI Near-River Semi-Volatiles Data Summary . . . . . . . . . . . . 2T-12a

2-13 K Area LFI Near-River Pesticides Data Summary . . . . . . . . . . . . . . . . 2T-13

2-14 K Area LFI Near-River Wet Chemistry and Anions Data Summary . . . . . . . 2T-14

2-15 K Area LFI Near-River Cation Data Summary . . . . . . . . . . . . . . . . 2T-15

2-16 K Area LFI Near-River Radioisotopes . . . . . . . . . . . . . . . . 2T-16

3-1 Comparison of Concentrations for Contaminants of Potential Concern . . . . . . 3T-1

3-2 Human Health Risk Summary, Noncarcinogenic Effects . . . . . . . . . . . . . . 3T-2

3-3 Human Health Risk Summary, Carcinogenic Effects . . . . . . . . . . . . . . . 3T-3

3-4 Ecological Summary for Radionuclides; Organism: Fish-Eating Duck . . . . . . . 3T-4

3-5 Ecological Summary for Nonradionuclides . . . . . . . . . . . . . . . . 3T-5

4-1 100-KR-4 Risk Based Contaminants of Potential Concern Data . . . . . . . . . 4T-1

4-2 Determination of Constituents Exceeding Potential ARAR . . . . . . . . . 4T-2

4-3 Potential Chemical-Specific ARAR and TBC . . . . . . . . . . . 4T-3

A-1 100-KR-4 Rejected Maximum Concentrations and Logic . . . . . . . . . . . . . AT-1a

A-2 100-KR-4 Rejected Near-River Maximum Concentrations and Logic . . . . . . . AT-2a 


\subsection{INTRODUCTION}

This limited field investigation (LFI) report is a secondary document summarizing the data collection and analysis activities conducted during the 100-KR-4 Groundwater Operable Unit LFI and the associated qualitative risk assessment (QRA).

\subsection{SITE LOCATION}

The 100-KR-4 Operable Unit is located in the northwestern portion of the Hanford Site along the southern shoreline of the Columbia River (Figure 1-1). The operable unit covers an area of approximately $3.1 \mathrm{~km}^{2}\left(1.2 \mathrm{mi}^{2}\right)$ and is located within Sections 5 and 6 of Township 13 North, Range 26 E, and Sections 31 and 32 of Township 14 North, Range 26 East of the Willamette baseline and meridian. The 100-KR-4 Operable Unit lies between Hanford grid coordinates N73500, N76700 and W63700, W71700.

The 100-KR-4 Operable Unit (Figure 1-2) is one of four operable units associated with the $100 \mathrm{~K}$ Area. The $100-\mathrm{KR}-1,100-\mathrm{KR}-2$ and 100-KR-3 Operable Units are source operable units. The $100-\mathrm{KR}-4$ Operable Unit includes the groundwater below the source operable units plus the adjacent groundwater, surface water, saturated sediments and aquatic biota impacted by operations associated with the $100 \mathrm{KE}$ and $\mathrm{KW}$ Reactors.

\subsection{SITE HISTORY}

The KW Reactor operated from 1955 to 1970 and the KE Reactor from 1955 to 1971. These reactors were used to produce plutonium for nuclear weapons, and used Columbia River water for cooling and other operations activities. The operation of the reactors and their ancillary facilities resulted in the disposal of large quantities of waste.

The primary concern for this LFI is the liquid waste because it is believed to have the greatest influence on the groundwater. The major liquid waste disposal sites (Figure 1-3) are:

- the reactor coolant water handling facilities which include the 116-KW-3 and 116-KE-4 Retention Basins; the 116-K-2 Trench; and the 116-K-1 Crib

- $\quad$ sludge handling burial ground 118-K-2

- miscellaneous small cribs supporting other facilities, 116-KW-1, 116-KW-2, 116-KE-1, and 116-KE-2.

Unique to the $100 \mathrm{~K}$ Area, the reactor inert gas syst ms were used to test a variety of gases. One of these gases was nitrogen. Due to the environ.nent of the inert gas system a series of radiological and chemical reactions took place when nitrogen was being used. The neutron flux through the gas shield was sufficient to generate carbon-14 by driving a proton 
from the nitrogen nucleus. This radioactive carbon oxidized, due to the atmosphere in the gas shield, and combined with water forming a weak carbonic acid solution. As the gas was recirculated through the 117-KE or $\mathrm{KW}$ Gas Recirculation Building the effluent gases were dried using an assortment of methods and the nitrogen atmosphere recirculated through the reactor. These unique circumstances led to the creation and subsequent disposal of an estimated $200 \mathrm{Ci}$ each of carbon-14 and tritium to french drains (116-KW-1 and 116-KE-1) adjacent to the individual reactors.

In 1978, following cessation of reactor operations in the $100 \mathrm{~K}$ Area, the fuel storage basins in both the KE and KW Reactors were used to store aging irradiated fuel from the $\mathbf{N}$ Reactor Ihis use continues today pending a decision on the final disposition of that fuel.

\subsection{LIMITED FIELD INVESTIGATION STRATEGY}

To expedite the initiation and reduce the cost of cleaning up contaminated sites at Hanford, the U.S. Department of Energy (DOE), the Washington State Department of Ecology (Ecology) and the U.S. Environmental Protection Agency (EPA) developed the Hanford Past-Practice Strategy (HPPS) (DOE-RL 1991). This strategy uses existing data to make decisions and is biased-for-action. If a site poses a risk to human health or the environment, the bias is to take action to clean it up. Figure 1-4 outlines the four decision paths of the HPPS. These paths are:

- Expedited response action (ERA) is performed when a rapid response is necessary to mitigate an unacceptable health or environmental risk from a site.

- Interim remedial measure (IRM) is performed at a site that is known to pose an unacceptable, non-time critical health or environmental risk.

- Limited field investigation is performed to gather any additional information necessary to determine whether or not an ERA or an IRM is necessary.

- $\quad$ Remedial investigation/feasibility study (RI/FS) is the baseline method of addressing potentially contaminated sites.

The LFI is an integral part of the RI/FS process and functions as a focused RI for selection of IRM. A QRA is performed as part of the LFI, and is focused on the principal risk drivers in the operable unit. The results of this assessment may be used to help determine the need for IRM. If an IRM is not justified, the site is still subject to further investigation and/or remediation. A further discussion of the LFI/IRM process is provided in Guidance for Conducting Remedial Investigations and Feasibility Studies under CERCLA (EPA 1988).

The LFI for the 100-KR-4 Operable Unit was conducted to determine the nature and extent of hazardous/radioactive materials present in the groundwater. This was done by collecting data from existing wells and seven new wells drilled for the RI/FS. The new wells were installed to define the groundwater quality in areas of potential public or 
environmental exposure (i.e., near springs along the Columbia River shoreline that are downgradient of contaminant sources), to define the groundwater quality immediately downgradient of priority and potential sources of groundwater contamination, and to define the extent of known contamination. Soil samples were collected for chemical and radioactive analyses and physical property determination. Aquifer tests were also performed and hydraulic heads were measured.

The LFI for the 100-KR-4 Operable Unit included the following tasks:

- geological investigation

- vadose zone investigation

- groundwater investigation

- data evaluation

- risk assessment

- verification of applicable or relevant and appropriate requirements (ARAR)

- $\quad$ LFI reporting

Several data compilation reports were prepared under Resource Conservation and Recovery Act (RCRA) and CERCLA programs as part of early characterization activities for the 100 Areas. Lindsey (1992) summarizes the geologic data available and the geologic setting of the 100 Areas. Peterson (1992) provides an inventory of wells, chemical data, and water-level data for the northern Hanford Site. Hartman and Peterson (1992) summarize hydrologic conditions for the 100 Areas, including water table maps, waste indicator constituents, and aquifer hydraulic properties. They include an analysis of existing wells relative to their potential for future use. Lewis and Pearson (1992) present a catalog of historical borehole geophysical data for the 100 Areas. Ledgerwood (1991) summarizes well construction and condition information for existing 100 Area wells.

A limited number of LFI tasks were conducted under a separate 100 Area sitewide effort. These tasks include:

- $\quad$ surface water and sediments investigation

- air investigation

- ecological investigation

Data compilations and summaries that pertain to these areas include: Dirkes (1992) which provides an extensive annotated bibliography for river-related investigations; Peterson and Johnson (1992) summarize historical riverbank seepage, sediment and nearshore monitoring well data, and relate it to results obtained during September 1991; Campbell et al. (1993) describes the extensive data acquisition capability that exists to gather data for the Hanford Site aquifer/Columbia River interaction investigations (Tri-Party Agreement Milestone M-30); and Weiss and Mitchell (1992) present a synthesis of ecological information for the 100 Areas. The potential ARAR are discussed in the 100 Area FS (DOE-RL 1993a). 


\subsection{DATA VALIDATION}

Data validation was performed by a qualified independent participant contractor. The validation responsibilities are defined in associated statements of work. All validation was performed in compliance with Westinghouse Hanford Company's (WHC) Sample Management Administration Manual (WHC 1990), Section 2.1 for inorganic analyses, Section 2.2 for organic analyses, and Sections 2.3 and 2.4 for radionuclide analyses. All data packages were verified. The data validation process is presented in:

- Data Validation Report for the 100-KR-4 Operable Unit Groundwater Samples (WHC 1993a)

- Data Validation Report for the 100-KR-4 Operable Unit Second Round Groundwater Samples (WHC 1993b)

- Data Validation Report for the 100-KR-4 Operable Unit Third Round Groundwater Sampling (WHC 1993c)

- Data Validation Report for the 100-KR-4 Operable Unit Fourth Round Groundwater Sampling (WHC 1993d).

Data used in this investigation were derived directly from the Hanford Environmental Information System (HEIS). Data validation is an ongoing process and may result in changes to the qualification codes associated with individual analyses. All reported data and associated validation qualifiers used in this report conform to those in the HEIS as of December 's, 1993. 
DOE/RL-93-79, Rev. 0

Figure 1-1 100 Area Reactor Locations

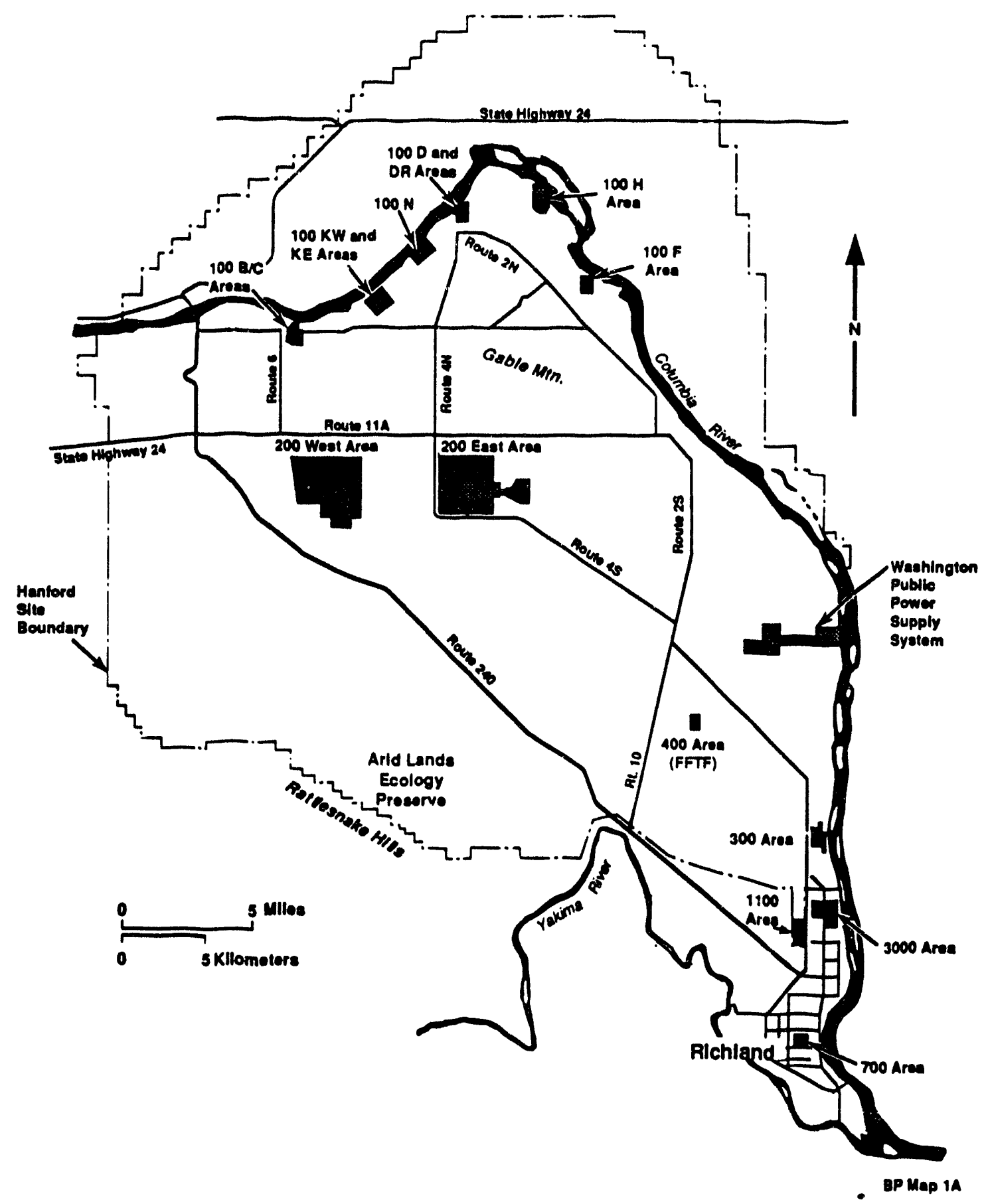

$1 \mathrm{~F}-1$ 
DOE/RL-93-79, Rev. 0

Figure 1-2 100-KR-4 Operable Unit and Well Locations

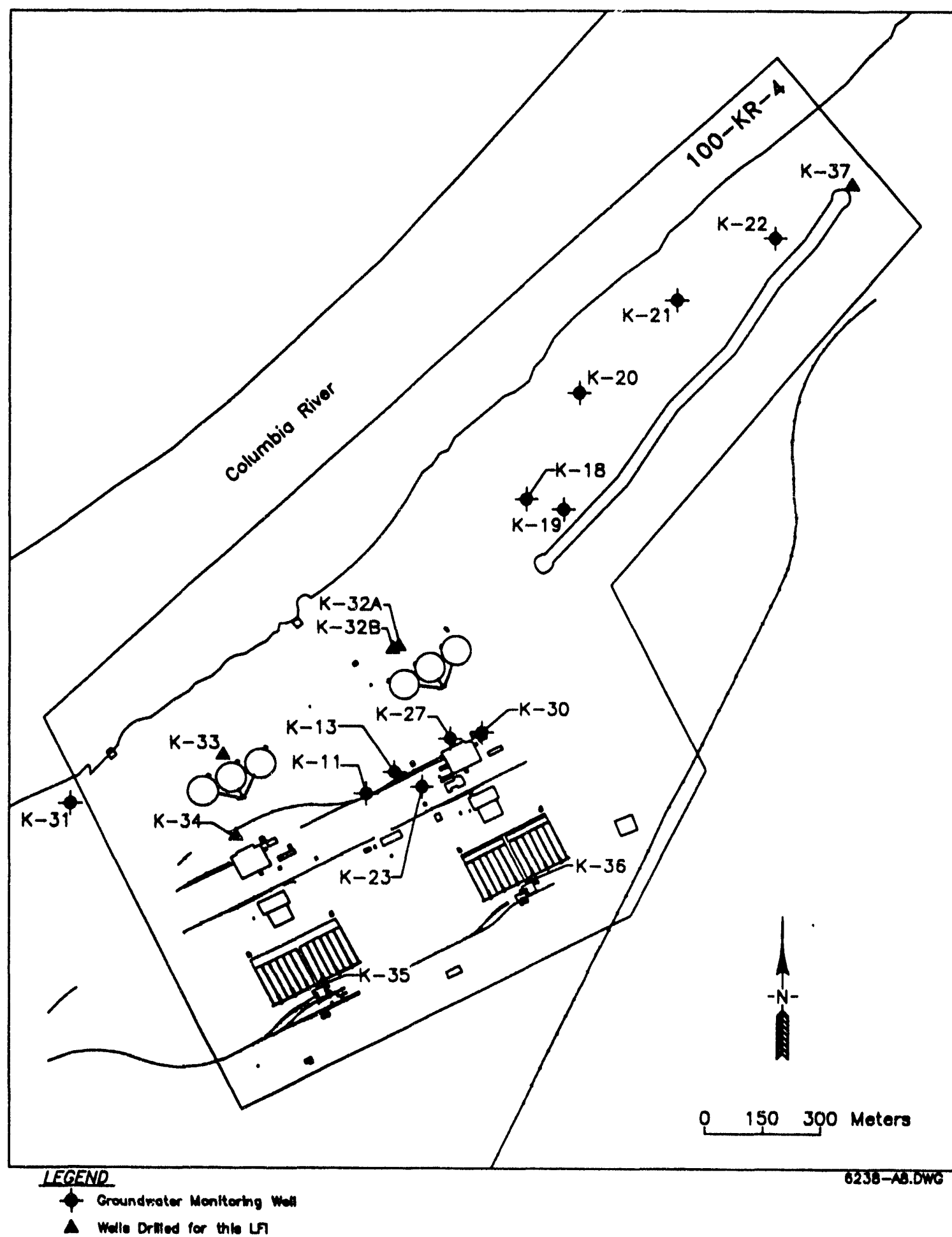

1F-2 


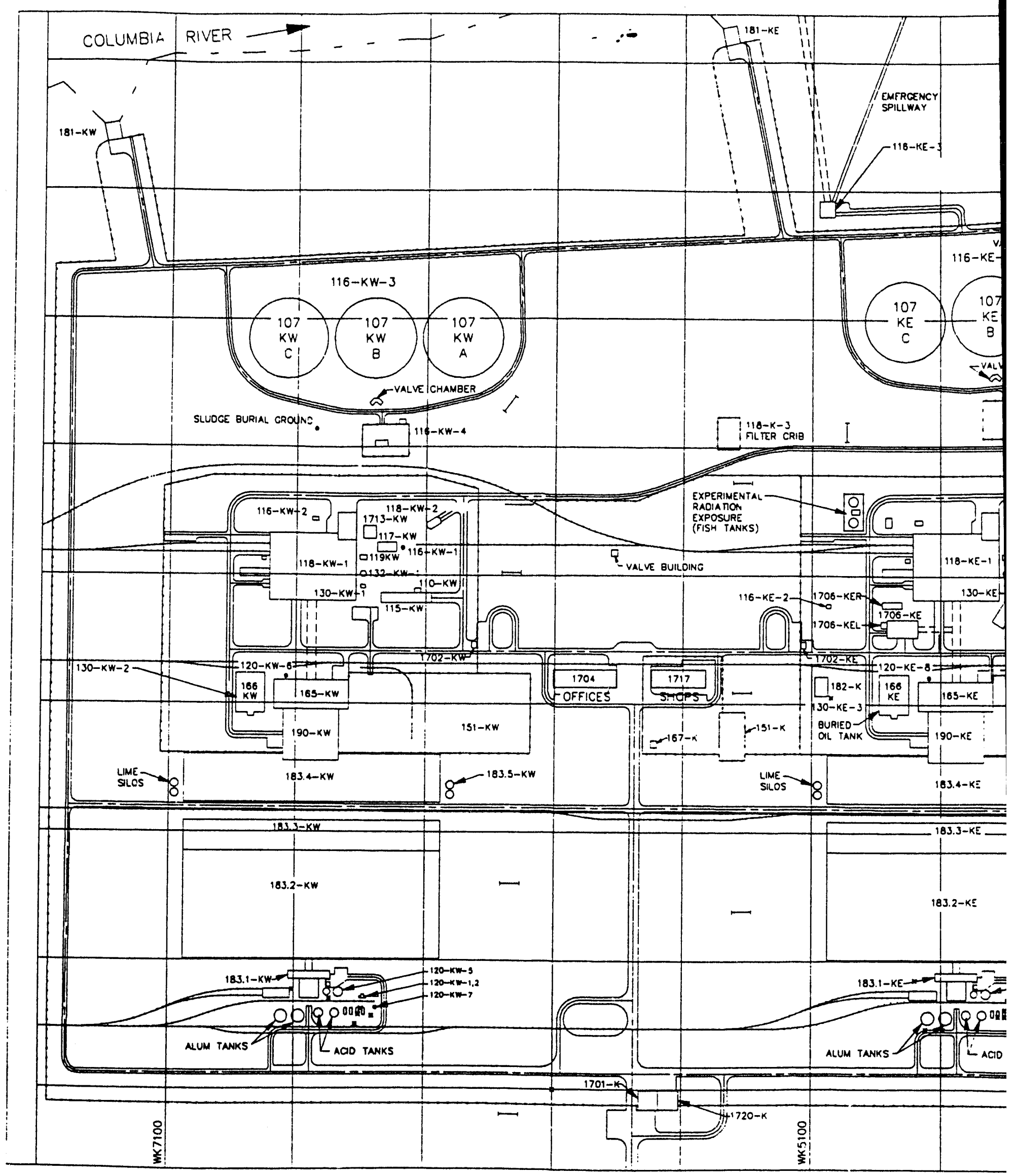


DOE/RL-93-79, Rev. 0

Figure 1-3 Waste Sites in the $100 \mathrm{~K}$ Area

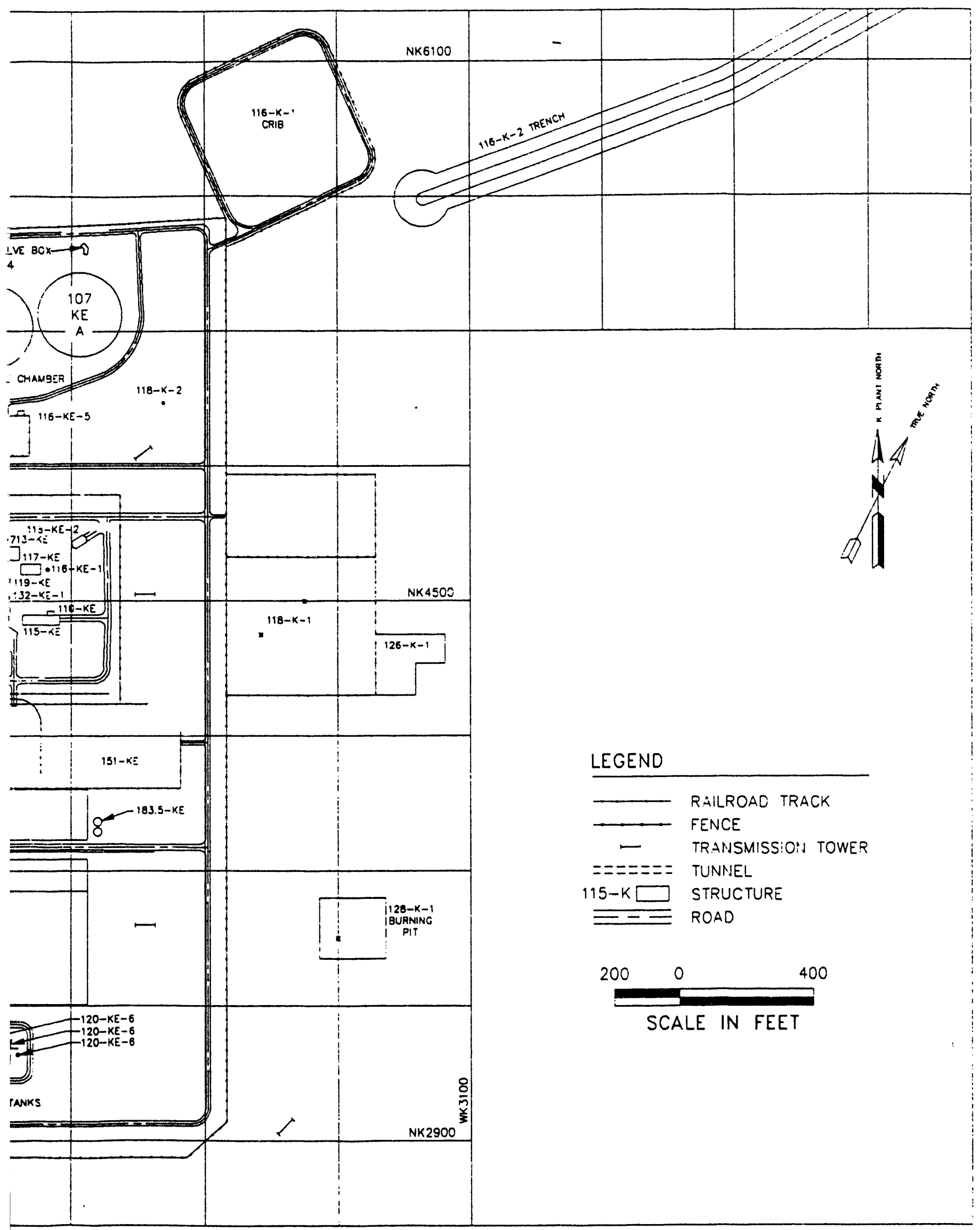


DOE/RL-93-79, Rev. 0

Figure 1-4 Hanford Past-Practice Strategy Process (DOE-RL 1991)

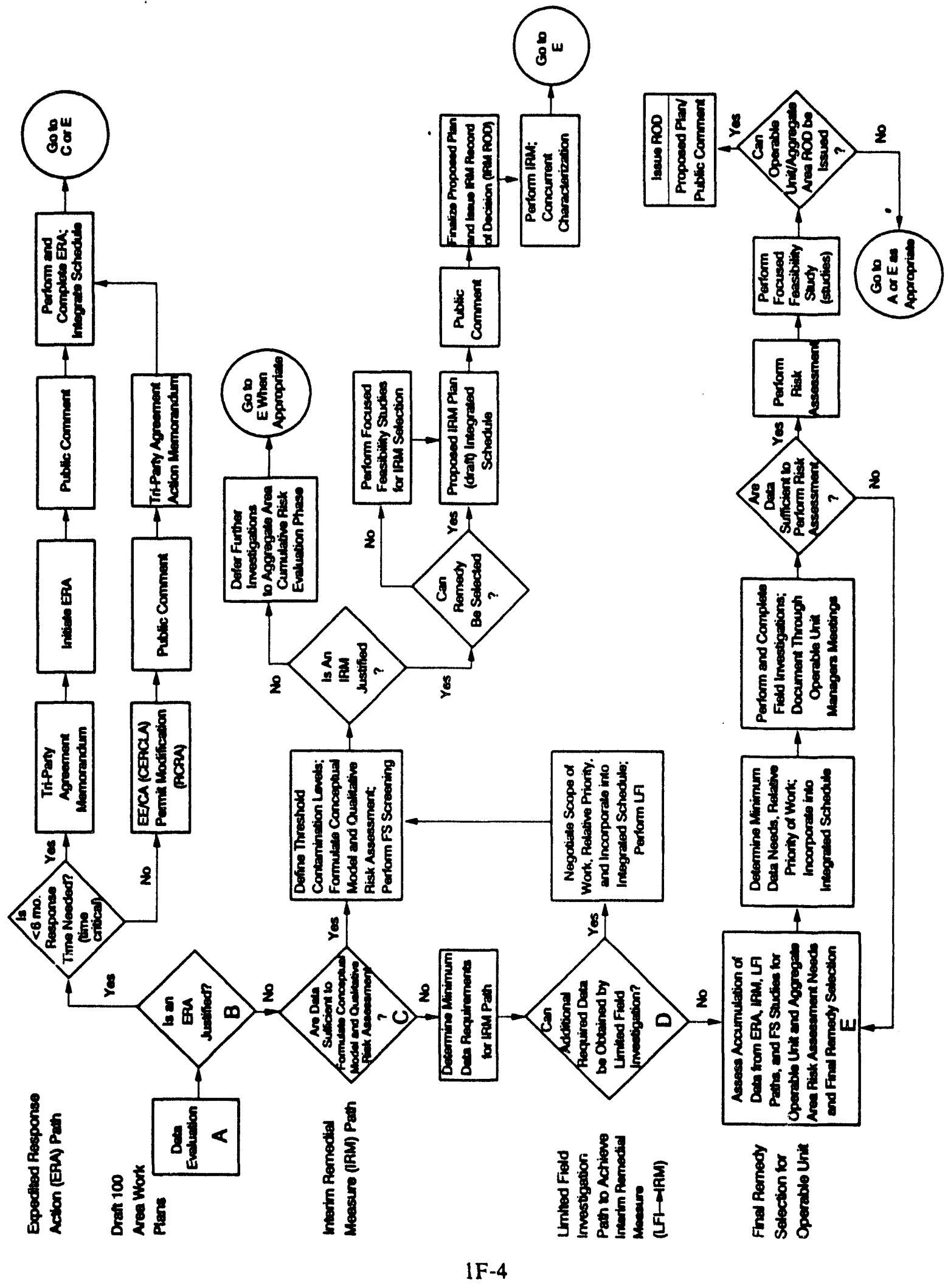


DOE/RL-93-79, Rev, 0

\subsection{INVESTIGATION ACTIVITIES AND RESULTS}

This chapter provides a summary of the activities performed and the data collected during the 100-KR-4 LFI.

\subsection{GEOLOGY}

During the LFI, one deep well (199-K-32B) and six shallow wells (199-K-32A, 199-K-33, 199-K-34, 199-K-35, 199-K-36, and 199-K-37) were installed (Figure 1-2) to further define the groundwater quality in areas of potential public or environmental exposure and to define the groundwater quality immediately downgradient of priority and potential sources of groundwater contamination. The justification for each well location is discussed in the 100-KR-4 Work Plan (DOE-RL 1992a). Boreholes were advanced using cable-tool drilling methods and split spoon or core barrel samplers. Detailed procedures for drilling are described in the Environmental Investigarions and Site Characterization Manual, Section 6.0 - Drilling (WHC 1988). A summary of the well construction for LFI wells is provided in Table 2-1.

Soil samples were collected and field screened for contaminants at $1.5 \mathrm{~m}(5 \mathrm{ft})$ intervals. Selected samples were submitted for further analysis. The shallow wells were

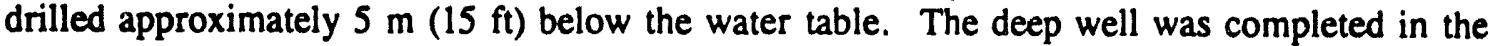
upper confined/semi-confined aquifer. All wells are interpreted as being completed in Unit E of the Ringold Formation.

The following discussions are based on all of the data available for the $100 \mathrm{~K}$ Area. The geologic descriptions of the $100 \mathrm{~K}$ Area are summarized from Lindberg (1993) and Lindsey (1991). The discussions of Lindsey (1991) and Lindberg (1993) have been revised to reflect the data derived from LFI wells.

\subsubsection{Topography}

The surface topography of the $100 \mathrm{~K}$ Area is the product of cataclysmic flood erosion and deposition, post-flood eolian activity and post flood erosion and deposition associated with the Columbia River. The $100 \mathrm{~K}$ Area lies on an essentially flat semi-arid bench south of the Columbia River. The elevation of the area ranges from approximately $150 \mathrm{~m}(492 \mathrm{ft})$

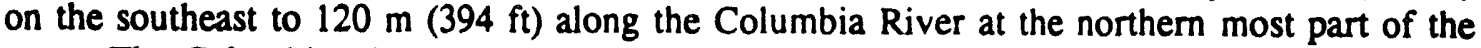
area. The Columbia River elevation is greatly influenced by Coyote Rapids near the upstream boundary of the operable unit. The elevation change across the majority of the operable unit is about $0.3 \mathrm{~m}(1 \mathrm{ft})$. The land surface slopes gradually toward the river, a steep bank, up to $11 \mathrm{~m}(36 \mathrm{ft})$ high is present at the edge of the river. 
DOE/RL-93-79, Rev. 0

\subsubsection{Structural Geology}

Structurally, the Hanford Site lies in the eastern portion of the Yakima Fold Belt. This belt consists of a series of segmented, narrow, asymmetric, and generally east-west trending anticlines that deform the underlying Columbia River Basalt Group (CRBG). Between these anticlines lie broad, shallow synclines. The Hanford Site is situated in the Pasco Basin, one of the largest of these synclines. The $100 \mathrm{~K}$ Area lies essentially along the axis of the Wahluke syncline, north of the Gable Mountain/Gable Butte anticline. The north limb of this syncline dips at about $5^{\circ}$, the south limb dips more steeply.

\subsubsection{Stratigraphy}

From the oldest to youngest, the CRBG with the interbedded Ellensburg Formation, and suprabasalt sedimentary deposits underlie the $100 \mathrm{~K}$ Area (Figure 2-1).

2.1.3.1 Columbia River Basalt Group and Ellensburg Formation. Miocene aged, tholeiitic, continental flood basalts cover more than $163,157 \mathrm{~km}^{2}$ in Washington, Oregon, and Idaho. The Elephant Mountain member of the Saddle Mountains Basalt Formation is the uppermost of the CRBG in the 100 Area (Figure 2-1). In the vicinity of the $100 \mathrm{~K}$ Area, only well 699-81-62 penetrates the upper basalt (Lindberg 1993). (Well 699-81-62 is located northeast of the 116-K-2 Trench.) Volcanoclastic and silicic deposits between Columbia River Basalt flows form the Ellensburg Formation. No wells penetrate the interbedded tuffs, paleosols and fluvial sands and gravels of the Rattlesnake Ridge interbed of the Ellensburg Formation.

2.1.3.2 Ringold Formation. The Ringold Formation overlies the Columbia River Basalts and is up to $185 \mathrm{~m} \mathrm{(607} \mathrm{ft)} \mathrm{thick} \mathrm{in} \mathrm{the} \mathrm{Pasco} \mathrm{Basin.} \mathrm{The} \mathrm{unit} \mathrm{pinches} \mathrm{out} \mathrm{against} \mathrm{basaltic}$ anticlinal flanks that bound the basin. The sedimentary deposits consist of semi-indurated clay, silt, fine- to coarse-grained sand, and pebble- to cobble-sized gravel. Five facies of the Ringold Formation recognized in the $100 \mathrm{~K}$ Area are:

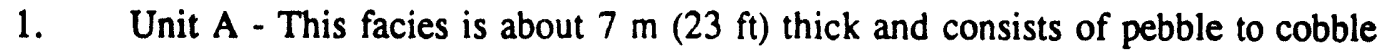
sized gravel with a fine- to medium-grained sand matrix. Grain size distributions are often bimodal; coarse-grained sand is rare. The sand fraction is quartz rich, giving it a tan color. Unit A most likely overlies basalt throughout the $100 \mathrm{~K}$ Area.

2. Lower Mud Unit - Overlying Unit A is a mud unit approximately $32 \mathrm{~m}$ (105 ft) thick. The mud is blue-gray to black, locally micaceous, lacustrine muds and brown to green fluvial overbank deposits.

3. Unit B - This facies is approximately $28 \mathrm{~m}$ ( $92 \mathrm{ft})$ thick and consists primarily of sand. The lower portion of the unit is a cross-bedded sand that is medium-grained, quartzose, and sometimes micaceous. The lower sand grades upward into a silty sand that is tan to grey-brown, locally tuffaceous and contains wood fragments. 
DOE/RL-93-79, Rev. 0

4. Unit $\mathrm{C}$ and Overbank-Paleosol Deposits - This facies is approximately $64 \mathrm{~m}$ (209 ft) thick and consists of muds and sandy muds that typically display characteristics of paleosols and fluvial overbank deposits. The sequence has three parts; an upper and lower part that are predominantly silt to sandy silt, and a middle section of gravelly sand.

5. Unit E - This facies ranges from $20 \mathrm{~m}(64 \mathrm{ft})$ to $41 \mathrm{~m}(136 \mathrm{ft})$ thick in boreholes near the $100 \mathrm{~K}$ Area. It is composed of predominantly coarse-grained material consisting of fluvial gravel and fluvial sands.

2.1.3.3 Hanford Formation. The Hanford formation in the vicinity of the $100 \mathrm{~K}$ Area is a wedge that increases in thickness away from the Columbia River. It ranges in thickness from 0 to about $37 \mathrm{~m}(120 \mathrm{ft})$. The unit reaches a thickness of about $24 \mathrm{~m}(80 \mathrm{ft})$ near the southwest corner of $100 \mathrm{~K}$ Area. Site wide, the Hanford formation consists of sand and gravel. It is gravel dominated in the $100 \mathrm{~K}$ Area. A sand dominated facies occurs locally in a few intervals, but is not sufficiently thick nor extensive to correlate from borehoie to borehole (Lindberg 1993).

2.1.3.4 Holocene Surface Deposits. The uppermost deposits beneath the $100 \mathrm{~K}$ Area consist of a thin, discontinuous layer of Holocene-aged eolian deposits, Columbia River alluvium and man-made backfill. Eolian deposits of fine-grained silty sand $<1 \mathrm{~m}(3 \mathrm{ft})$ thick, are present locally. Columbia River alluvium consists of channel deposited gravels, coarse-grained sands and overbank silts and sands.

\subsubsection{Hanford Formation/Ringold Formation Contact}

The $100 \mathrm{~K}$ Area differs geologically from surrounding areas $(100 \mathrm{~B} / \mathrm{C}$ and $100 \mathrm{~N}$ Areas) because the Ringold Formation is exposed, not only along the bank of the Columbia River, but also at distances of up to $366 \mathrm{~m}$ (1200 ft) inland. Ringold Formation Unit E may be more cemented around $100 \mathrm{~K}$, and therefore more resistant than it is in nearby areas. Evidence of this increased resistance to erosion is present in Coyote Rapids, immediately upstream of the $100 \mathrm{~K}$ Area, where the unit resists the erosive power of the Columbia River. The contact between the Hanford formation and the Ringold Formation is generally noted by a slight increase in cementation. Much of the Hanford formation in vicinity of the $100 \mathrm{~K}$ Area consists of reworked Ringold Formation.

\subsubsection{Physical Properties}

Ringold and Hanford formation physical properties for the 100 Areas were investigated using samples collected from the $H, D / D R$, and $B / C$ Areas to help evaluate contaminant migration. Additional samples were collected during the 100-KR-4 LFI from wells $199-\mathrm{K}-33,199-\mathrm{K}-35$ and $199-\mathrm{K}-37$ for the same purpose. In general, samples were collected from three wells in each reactor area; three samples were collected from each well. One sample was collected from the top half of the well, one from the bottom half and one from below the groundwater level. These soil samples were tested for: particle size 
distribution, moisture content, moisture retention, and saturated hydraulic conductivity. Unsaturated hydraulic conductivity and buik density were calculated. Due to the difficulty of collecting samples of coarse-grained materials, the physical property results are biased toward finer-grained soils. Although the cable tool method of drilling was used to advance the boreholes, these soil samples were collected using a drive barrel thus minimizing the bias due to the drilling method. The data are available in the project files.

\subsection{HYDROGEOLOGY}

Table 2-2 describes the construction, completion, sampling method and screened interval for the wells existing in the 100-KR-4 Operable Unit. Figure 2-2 depicts the water table of the 100-KR-4 Operable Unit for April 1993. As shown, the water table slopes steeply to the northwest, this configuration is typical of low river stage groundwater conditions. Figure 2-3 depicts the water table during June 1993 and is typical of high river stage conditions.

The vadose zone is comprised of backfill, Holocene surficial deposits, the Hanford formation and, the uppermost part of the Ringold Formation. This unsaturated zone ranges in thickness from zero at the Columbia River shoreline to about $30 \mathrm{~m}$ (100 ft) near the southeast boundary of the $100 \mathrm{~K}$ Area. Most of the vadose zone lies within the gravel-dominated facies of the Hanford formation, where it exists and the upper portion of the Ringold Formation.

The unconfined aquifer system underlying the $100 \mathrm{~K}$ Area is comprised exclusively of Unit E of the Ringold Formation. Migration of contaminants is impeded by the low hydraulic conductivity of these soils. Evidence of the low conductivity is apparent from Figures 2-2 and 2-3 where relatively steep gradients are maintained regardless of river stage. Near the reactors, high water influences of the Columbia River do not extend far inland. Further downstream, in the vicinity of the 116-K-2 Trench, river influence is noted more than $600 \mathrm{~m}$ from the bank. Groundwater flow is northwesterly toward the river under both high and low river discharge conditions. Additional wells in the area would serve to further refine the interpretation of groundwater flow. The boulder strewn ground surface in the vicinity of $100 \mathrm{~K}$ is evidence of the high velocity flow environment during the periods of glacial flooding.

Figures 2-2 and 2-3 point out a steepening of groundwater gradient near the KE Reactor. There are at least three possible explanations for this feature:

- The hydrogeology of the K Area is sufficiently variable and tight to produce the feature.

- Leakage is occurring from the 183-KE Basins and their associated piping, resulting in an increased gradient to accommodate increased groundwater flow. 
- Leakage from the $105 \mathrm{KE}$ Fuel Storage Basins causes a change in hydraulic equilibrium. This scenario is the least likely due to the minimal leakage $<7$ gpd.

As seen in Figure 2-3, the feature disappears during high flow periods of the Columbia River, independent of $\mathrm{K}$ Area activities, leading to the probable cause of the feature being local hydrogeologic conditions, not recharge from surface sources.

One implication of the low hydraulic conductivity values (Table 2-3) determined during the LFI is that mounding beneath the 116-K-2 Trench may have been significant

during its use. The length of the trench (almost one mile) provides evidence that a large area was needed to accepi the inflow without breaching.

\subsubsection{Aquifer Test Results}

Aquifer properties were tested in each of the seven wells drilled during the LFI. The "slug" test method was used to perform the tests and the Bouwer and Rice method (Bouwer and Rice 1976, Bouwer 1989) was used to analyze the resulting data. All wells were completed in the Ringold Formation; the test results reflect the low hydraulic conductivity typical of this unit (Hartman and Peterson 1992). Results of these tests are provided in Table 2-3.

Slug test hydraulic conductivities do not necessarily correlate directly with expected hydraulic conductivities based solely on the geologist's logs describing the soils. However, values obtained during the LFI correspond very well with anticipated values for the Ringold Formation. All wells were tested using a $3.6 \mathrm{~L}\left(0.13 \mathrm{ft}^{3}\right)$ slug. The slug was rapidly lowered into the well. The water level rose, saturating previously unsaturated material. The water level changes were recorded electronically until the water level equilibrated (injection test). Measurements taken during this portion of the test were not analyzed due to the difficulties associated with addressing the saturation of previously unsaturated soils.

After the water level equilibrated, the slug was rapidly removed and the water level changes recorded until they again reached equilibrium (withdrawal test). Only these withdrawal tests were analyzed.

The hydraulic conductivity values determined for the six shallow wells ranged from a low of $19 \mathrm{ft} /$ day in well $199-\mathrm{K}-33$, to a high of $145 \mathrm{ft} /$ day in well $199-\mathrm{K}-37$. These values are generally representative of the Ringold Formation (Hartman and Peterson 1992).

\subsection{GEOPHYSICAL LOGGING}

All boreholes were logged using gross gamma techniques. The description of work called for spectral gamma ray logging in all holes in which a gross gamma log exceeded 100 counts per second. No wells exceeded the threshold count rate, therefore no spectral gamma ray logs were run. 
DOE/RL-93-79, Rev. 0

\subsection{SOIL CONTAMINATION}

Samples of vadose zone soils were collected during the installation of groundwater monitoring wells. These samples were analyzed to determine if the soil retained contaminants from exposure to contaminated groundwater or process effluent. Where possible, samples were collected from $1.5 \mathrm{~m}$ and $3 \mathrm{~m}(5 \mathrm{ft}$ and $10 \mathrm{ft}$ ) above the current water table and at $1.5 \mathrm{~m}(5 \mathrm{ft})$ below the water table. In addition to these set sampling depths, samples were to be collected if field screening (photoionization detector and/or gamma or beta) indicated volatile organic compounds of $10 \mathrm{ppm}$ or greater or radiation exceeding twice background. No additional samples were collected due to field screening; all drill cuttings were within the preselected parameter boundaries. Table $2-4$ provides a summary description of the constituents associated with soils analyzed. Soils exhibit concentrations of analytes that are generally within the bounds of background ranges (DOE-RL 1993b). Inorganic constituents are all within the range of background; semi-volatile constituents were all below the contracted detection limit for soils; radionuclides were slightly elevated and volatile constituents were generally low except for acetone and methylene chloride. Acetone and methylene chloride were not found in groundwater samples leading to the conclusion that these constituents are laboratory artifacts.

\subsection{GROUNDWATER CONTAMINATION}

A total of 23 wells (Table 2-1) (Figure 2-4) were sampled and analyzed as part of this LFI. Of these wells, 18 were within the boundaries of the 100-KR-4 Operable Unit and five were outside the unit. The five wells outside the boundaries were sampled to provide data on the quality of groundwater entering from outside and potentially impacting groundwater quality. Two of the outside wells (699-65-72 and 699-66-64) were sampled only during the second round.

Of these 23 wells, seven were new wells tapping the unconfined aquifer that were drilled and constructed according to strict specification for resource protection wells (WHC 1988) during this LFI. These wells were designed and located to provide data on the quality of groundwater entering the Columbia River and to provide data to evaluate contaminants near known waste sources. Groundwater chemistry data were obtained from wells drilled under this LFI, from wells drilled for specific $100 \mathrm{~K}$ Area monitoring activities and from other existing wells determined to be "fit-for-use" as monitoring structures (Ledgerwood 1991). Groundwater samples from all existing "fit-for-use" wells and new wells were collected during September and December 1992 and March and June 1993; these samples were analyzed for Comprehensive Environmental Response, Compensation and Liability Act (CERCLA) contract laboratory program (CLP) target compound list (TCL) and target analyte list (TAL) constituents, specific anions that might be present, and for radionuclides. The detailed results of these analyses are available through the Administrative Record and are not duplicated here.

Historical data are available for the wells existing before initiation of the LFI. These wells were constructed for environmental monitoring, facility monitoring or other purposes. The wells have been samplat at various frequencies under site programs. Historically, 
environmental sampling has been conducted primarily to determine radiological parameters; other parameters have included nitrate and chromium. Facility monitoring programs have been designed to determine only a limited suite of analytes associated with the specific facility. Limited field investigation generated data were reviewed in conjunction with both environmental and facility specific data.

\subsubsection{Determination of Contaminants of Concern}

Limited field investigation specific data were analyzed following the flow chart illustrated in Figure 2-5. This process was used to determine which analytes were of concern to human health or environmental quality. The following is a brief discussion of that process:

- Determine the maximum concentration for each analyte in the $100 \mathrm{~K}$ Reactor Area. All wells are addressed.

- Is the analyte an EPA Region X excluded element (aluminum, calcium, iron, magnesium, potassium or sodium)? These elements have been determined to be nontoxic or essential nutrients and are categorically excluded from the list of contaminants of potential concem (COPC) for the human health QRA. These constituents were retained for consideration in the ecological QRA.

- Are the LFI selected maxima internally and externally consistent? Are the maximum analyte concentrations consistent with duplicate values (internal consistency \#1)? Are the concentrations consistent between sampling rounds (internal consistency $\# 2$ )? Is the contaminant expecied based on site operations or data from the closest nearby wells (external consistency)? (Note: nearest wells were evaluated to help determine if a contaminant was "expected.") If a maximum analyte concentration fails all of these tests then the value is determined to be inconsistent and the next highest concentration value is selected and evaluated.

An example of inconsistency is the Round 3 analysis of well 199-K-21. Concentrations for virtually all constituents were one order-of-magnitude greater than previous rounds, surrounding wells and Round 4 analyses. This single sample would provide extraordinary impact on risk and decisions regarding IRM or potentially ERA status. The lack of consistency was incompatible with the hydrology and geochemistry of the site, so the entire analysis was dropped from consideration.

Are the analytes found in laboratory blanks associated with the sample exhibiting the maximum concentration? If the analyte is found in the associated blank, the EPA 5x-10x rule is applied (EPA 1989). For analytes commonly used in the laboratory, the value is eliminated if it is $<10$ times the blank concentration. For other analytes, the value is eliminated if it is $<5$ times the blank concentration. 
- Does the maximum concentration exceed Hanford and/or local background? Analytes present at or below background concentrations are excluded from additional consideration. Background values are from Hanford Sitewide characterization of the groundwater (DOE-RL, 1992b). The characterization of background involved the determination of tile types, and concentrations of selected analytes, thet exist naturally in the groundwater at the Hanford Site. Provisional threshold levels (based on a tolerance interval approach Washington Administrative Code [WAC] 173-340-708) for inorganic analytes, gross alpha, gross beta, total radium, total strontium, total uranium, and selected anions were developed from the characterization effort to represent sitewide background conditions (DOE-RL 1992b).

- These screened data are then passed on to the QRA as maximum defensible concentrations of COPC. The QRA, in accordance with Hanford Site Baseline Risk Assessment Methodology (HSBRAM) (DOE-RL 1993c) further screens the data against risk and ARAR values to provide a refined list of COPC.

This method assures that COPC used in the QRA are the maximum defensible concentrations, thus providing a conservative yet realistic assessment of risk.

This screening method is similar to the method used for the source operable unit LFI. The major difference is that for the source LFI, only one round of data were available, therefore it was not possible to do a consistency check.

Tables 2-5 through 2-16 show the results of the above screening and the constituents identified as human health COPC. The screening process was performed for near-river wells (199-K-13, 199-K-18, 199-K-20, 199-K-21, 199-K-22, 199-K-31, 199-K-32A, 199-K-33, 199-K-34 and, 199-K-37) for the ecological evaluation. For inorganic constituents only data from unflitered samples were screened for both the ecological and human health evaluations.

The resulting COPC brought forward for comparison against potential ARAR and further analysis in the QRA included: aluminum, arsenic, cadmium, calcium, chloride, chloroform, chromium, iron, lead, manganese, nickel, nitrate, silver, sulfate, trichloroethene, tritium, uranium $(233 / 234,238$, and total), vanadium, zinc, carbon-14, strontium-90, and technetium-99. 
DOE/RL-93-79, Rev. 0

Figure 2-1 Stratigraphic Column of the 100-KR-4 Operable Unit

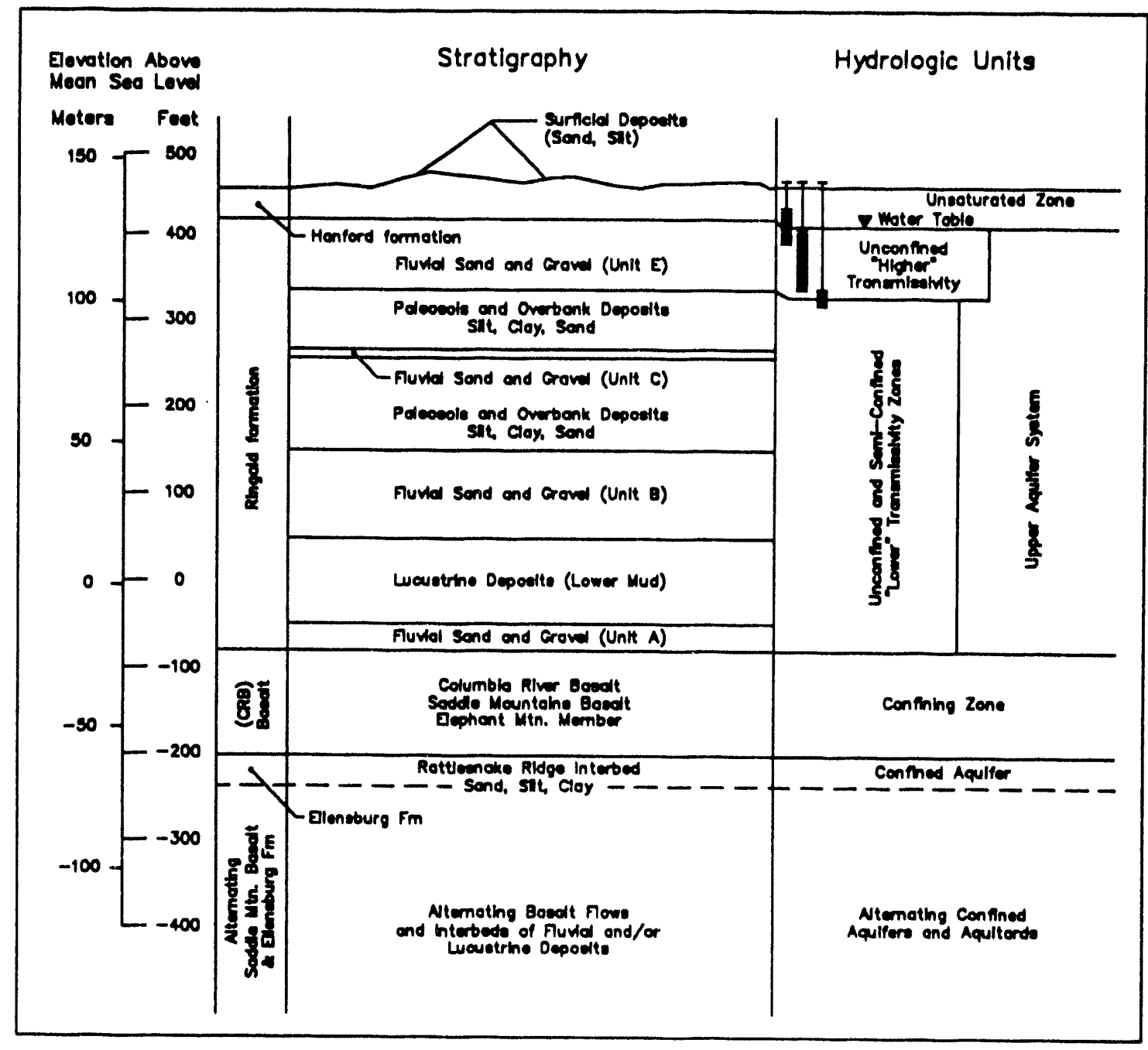

B238A19.0WG 
DOE/RL-93-79, Rev. 0

Figure 2-2 Water-Table Elevations in the $100 \mathrm{~K}$ Area, April 1993

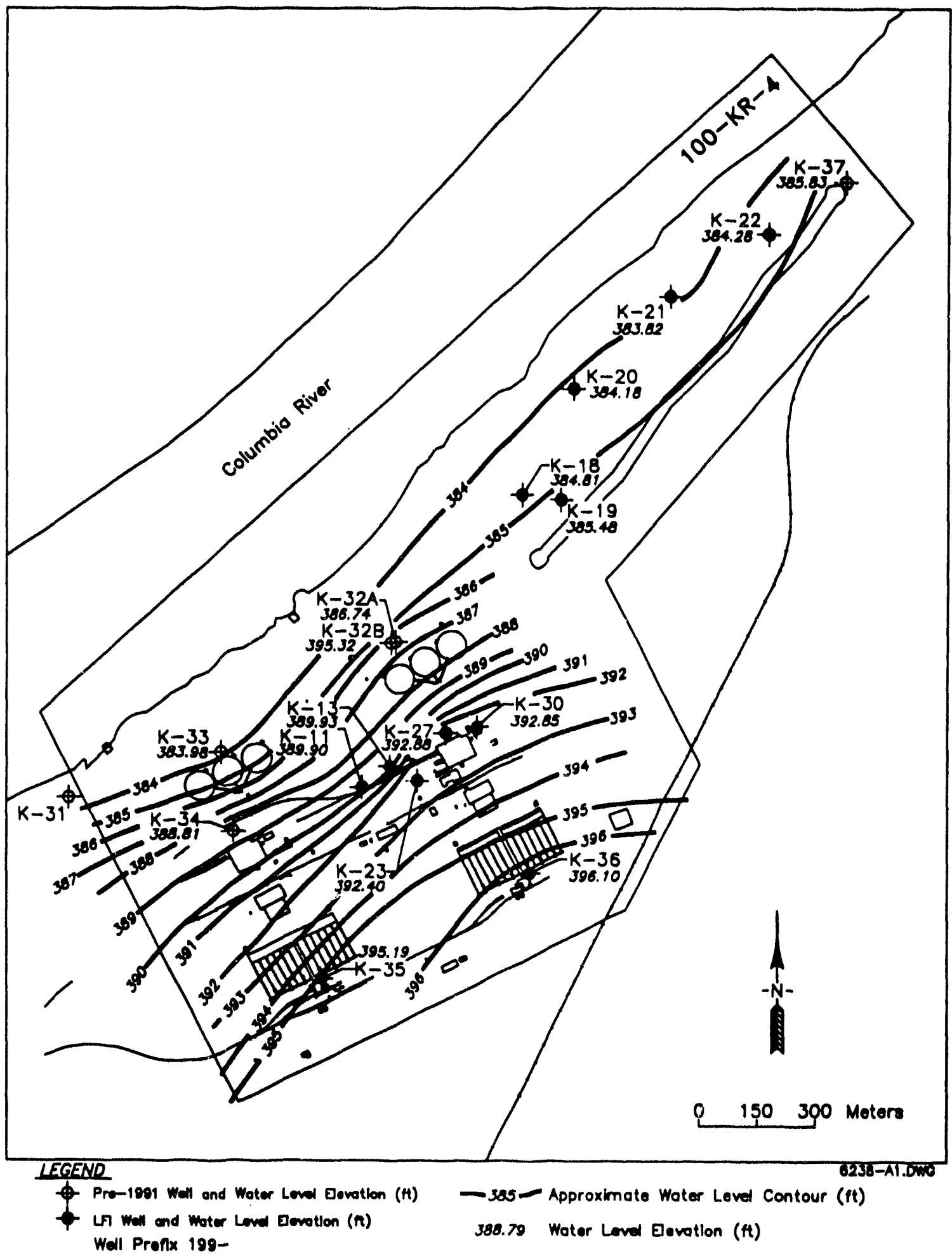




\section{DOE/RL-93-79, Rev. 0}

Figure 2-3 Water-Table Elevations in the $100 \mathrm{~K}$ Area, June 1993

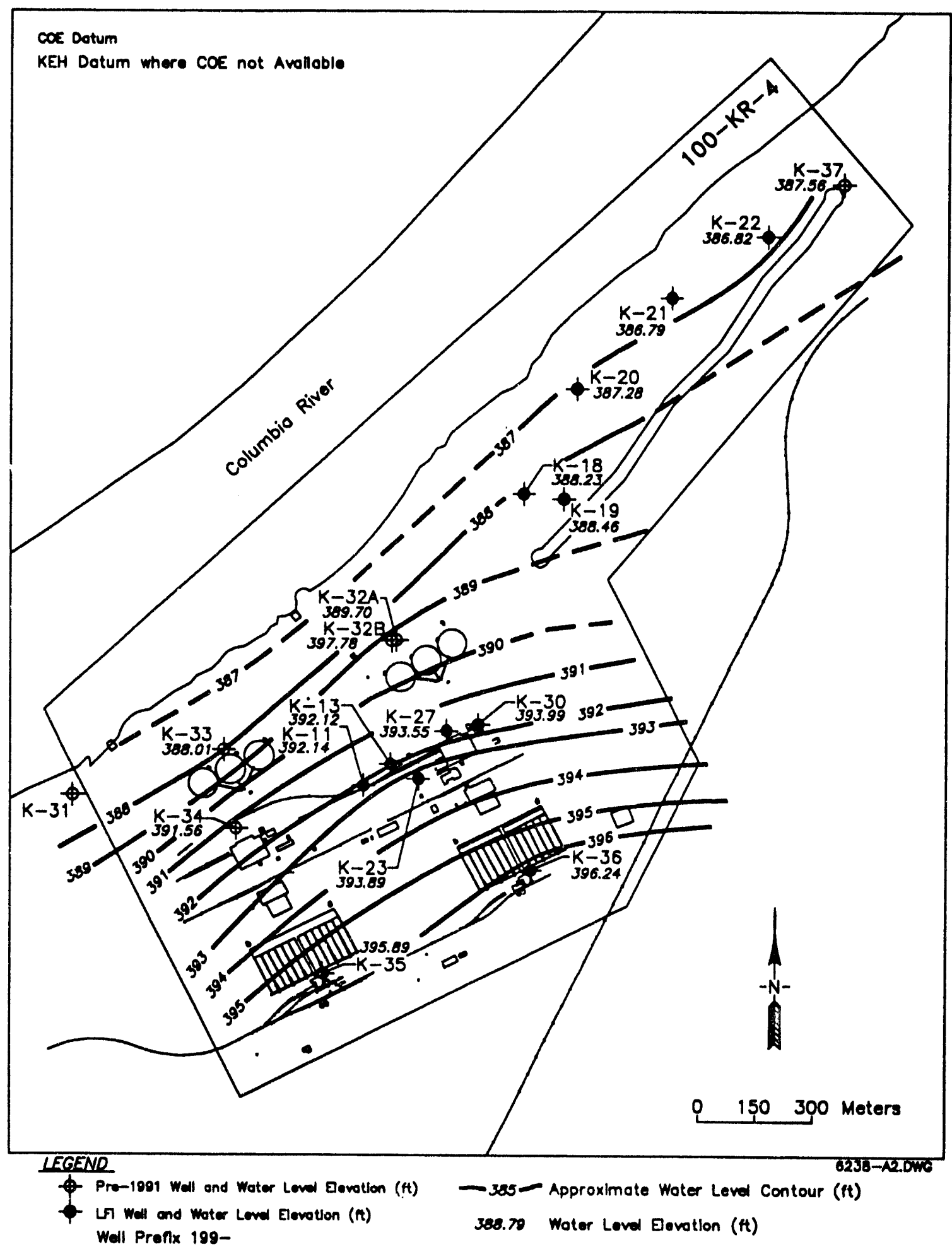




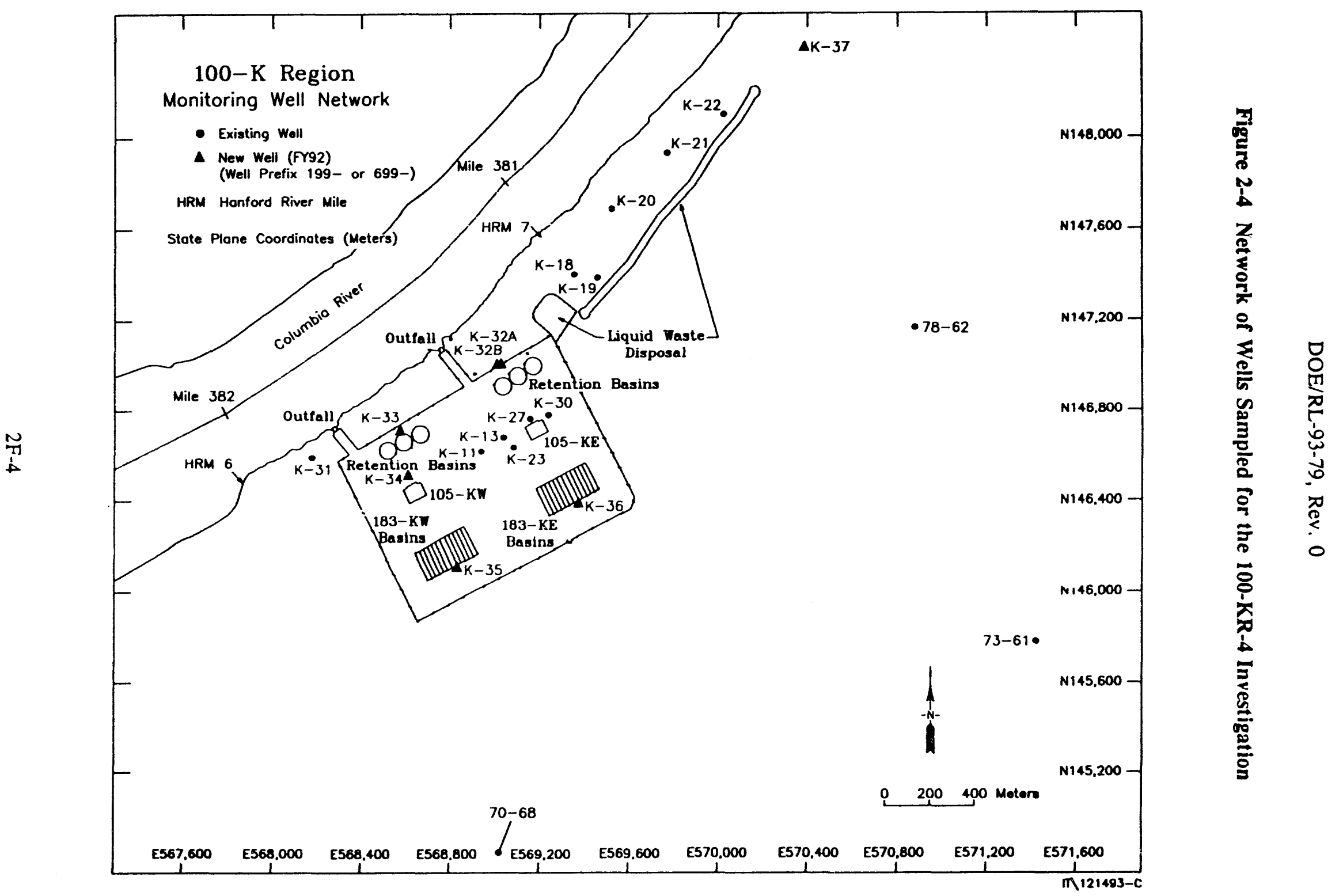




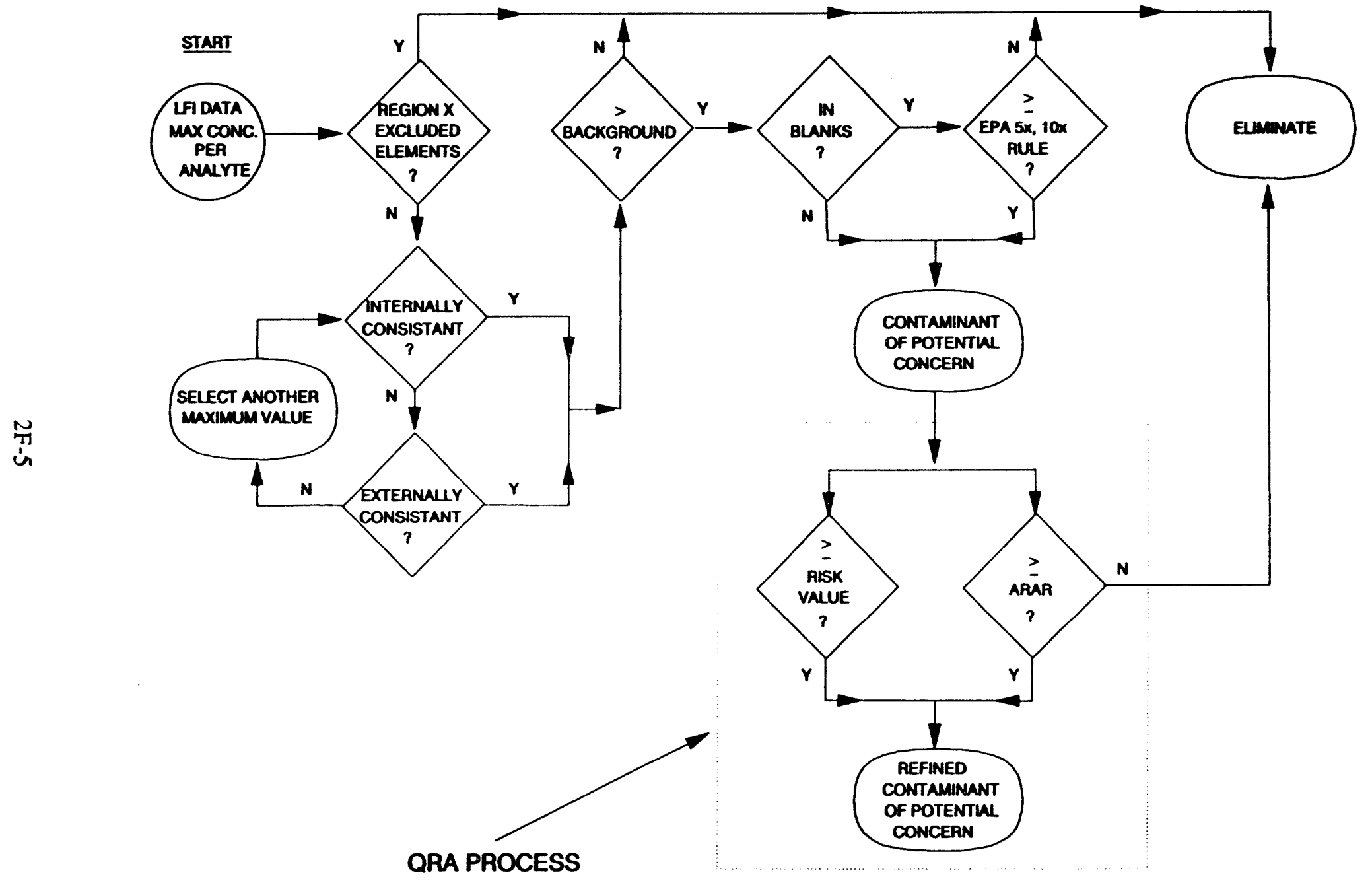

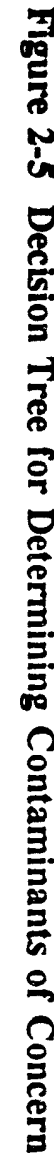




\begin{tabular}{|c|c|c|c|c|c|c|c|}
\hline $\begin{array}{c}\text { WELL } \\
\text { NUMBER }\end{array}$ & $\begin{array}{c}\text { DEPTH } \\
\text { (ft) }\end{array}$ & $\begin{array}{c}\text { CASING } \\
\text { DIA. } \\
\text { (in) } \\
\end{array}$ & COMPLETION ${ }^{*}$ & $\begin{array}{l}\text { SCREEN } \\
\text { INTERVAL } \\
\text { (ft) } \\
\end{array}$ & $\begin{array}{l}\text { SAMPLE } \\
\text { METHOD }^{b}\end{array}$ & $\begin{array}{c}\text { AQUIFER } \\
\text { TEST AND } \\
\text { METHOD } \\
\end{array}$ & FORMATION \\
\hline 199-K-32A & 65.10 & 4 & Screen & 45.1-65.1 & Pump & Slug & Ringold \\
\hline 199-K-32B & 167.58 & 4 & Screen & $\begin{array}{l}147.58- \\
167.58 \\
\end{array}$ & Pump & Not Run & Ringold \\
\hline 199-K-33 & 66.46 & 4 & Screen & $46.46-66.46$ & Pump & Slug & Ringold \\
\hline 199-K-34 & 87.44 & 4 & Screen & 67.44-87.44 & Pump & Slug & Ringold \\
\hline $199-K-35$ & 109.15 & 4 & Screen & $\begin{array}{l}89.15- \\
109.15\end{array}$ & Pump & Slug & Ringold \\
\hline $199-K-36$ & 109.53 & 4 & Screen & $\begin{array}{l}89.53- \\
109.53\end{array}$ & Pump & Slug & Ringold \\
\hline 199-K-37 & 63.97 & 4 & Screen & 43.97-63.97 & Pump & Slug & Ringold \\
\hline
\end{tabular}

- All screens constructed of stainless steel

- All pumps installed were Hydrostar 
DOE/RL-93-79, Rev. 0

Table 2-2 Wells Sampled During 100-KR-4 LFI

\begin{tabular}{|c|c|c|c|c|}
\hline WELL & ROUND 1 & ROUND 2 & ROUND 3 & ROUND 4 \\
\hline $199-\mathrm{K}-11$ & $\mathbf{X}$ & $\mathbf{X}$ & $\mathrm{X}$ & $X$ \\
\hline $199-\mathrm{K}-13$ & $x$ & $x$ & $x$ & $\mathrm{X}$ \\
\hline $199-K-18$ & $\mathrm{x}$ & $x$ & $\mathrm{x}$ & $x$ \\
\hline $199-K-19$ & & & $\mathrm{X}$ & $\mathrm{X}$ \\
\hline $199-K-20$ & $\mathrm{x}$ & $X$ & $x$ & $\mathrm{X}$ \\
\hline $199-K-21$ & $x$ & $\mathrm{X}$ & $\mathbf{x}$ & 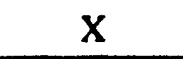 \\
\hline $199-K-22$ & $\mathrm{X}$ & $X$ & $x$ & $\mathbf{X}$ \\
\hline $190-K-23$ & $\mathrm{X}$ & $\mathrm{X}$ & $\mathrm{X}$ & $\mathrm{X}$ \\
\hline $199-K-27$ & $x$ & $X$ & $X$ & $\mathbf{X}$ \\
\hline $199-\mathrm{K}-30$ & $\mathrm{x}$ & $\mathrm{X}$ & $x$ & $x$ \\
\hline $199-K-31$ & $\mathrm{X}$ & $\mathrm{X}$ & $\mathrm{X}$ & $\mathrm{X}$ \\
\hline 199-K-32A & $\mathrm{X}$ & $\mathrm{X}$ & $\mathrm{X}$ & $\mathbf{X}$ \\
\hline 199-K-32B & $x$ & $\mathrm{X}$ & $x$ & $\mathbf{X}$ \\
\hline 199-K-33 & $\mathrm{X}$ & & $x$ & $\mathrm{X}$ \\
\hline 199-K-34 & $\mathrm{X}$ & $\mathrm{X}$ & $\mathrm{X}$ & $\mathbf{X}$ \\
\hline $199-K-35$ & $x$ & $x$ & $x$ & $\mathrm{x}$ \\
\hline $199-K-36$ & $\mathrm{X}$ & $\mathrm{x}$ & $x$ & $\mathrm{X}$ \\
\hline 199-K-37 & $x$ & $x$ & $x$ & $\mathrm{x}$ \\
\hline $699-73-61$ & $\mathrm{X}$ & $x$ & $x$ & $\mathrm{x}$ \\
\hline $699-78-62$ & $\mathrm{X}$ & $x$ & $x$ & $\mathrm{X}$ \\
\hline $699-70-68$ & $\mathrm{X}$ & $\mathrm{x}$ & $x$ & $\mathrm{x}$ \\
\hline $699-65-72^{*}$ & & $\mathrm{X}$ & & \\
\hline 699-66-64* & & $\mathrm{x}$ & & \\
\hline
\end{tabular}

* Wells sampled in excess of agreed upon network. 
DOE/RL-93-79, Rev. 0

Table 2-3 Summary of Aquifer Test Data, 100-KR-4 Operable Unit

\begin{tabular}{|c|c|}
\hline Well & $\begin{array}{c}\text { Hydraulic } \\
\text { Conductivity } \\
\text { (ft/day) }\end{array}$ \\
\hline $199-\mathrm{K}-32 \mathrm{~A}$ & 80 \\
\hline $199-\mathrm{K}-33$ & 19 \\
\hline $199-\mathrm{K}-34$ & 68 \\
\hline $199-\mathrm{K}-35$ & 124 \\
\hline $199-\mathrm{K}-36$ & 87 \\
\hline $199-\mathrm{K}-37$ & 145 \\
\hline
\end{tabular}


DOE/RL-93-79, Rev. 0

Table 2-4 Range of Soil Chemical and Radiological Analyses

\begin{tabular}{|c|c|c|c|}
\hline Anabote & Concentration Range & Anaty te & Concentration Range \\
\hline \multicolumn{2}{|l|}{ INORCANICS (mo/kg) } & \multicolumn{2}{|c|}{ PADIONUCLIOES (pCl/q) } \\
\hline Numinum & $3980 \cdot 7700$ & Groses alpha & $0.8 .2 \mathrm{~J}$ \\
\hline Antimony & $U .4 .3 \mathrm{BN}$ & Gross bota & U.19 \\
\hline Aresnio & $0.23 \mathrm{~B} \cdot 4.4 \mathrm{~S}$ & Carbon.14 & $4.24 J$ \\
\hline Barium & $32.98 \cdot 65$ & Potassium 40 & $6 \cdot 16$ \\
\hline Bendilium & $\mathrm{U} \cdot 0.4 \mathrm{~B}$ & Strontium-90 & $u \cdot 1$ \\
\hline Cadmium & $\mathrm{U} \cdot 0.54 \mathrm{~B}$ & Radium-220 & U. 0.53 \\
\hline Calcium & $1890 \cdot 7730$ & Thorium-228 & $U \cdot 1.1$ \\
\hline Chromium & $4.6 *-25.3 *$ & Thorium-232 & U.1.1 \\
\hline Cobalt & $4.18 \cdot 14.2$ & Uranium-233/234 & $0.2 \mathrm{~J} \cdot 0.59$ \\
\hline Coppor & $9 \cdot 21.4 \mathrm{E}$ & Uranium-238 & U. 0.59 \\
\hline Iron & $7840 \cdot 25500$ & Plutonium-239/240 & $U \cdot 0.16$ \\
\hline Magnosium & $2610 \cdot 5030$ & \multicolumn{2}{|l|}{ ANIONS $(\mathrm{mg} / \mathrm{kg})$} \\
\hline Manganose & $156 \cdots N \cdot 330$ & Fluoride & $1.8 \cdot 3.4$ \\
\hline Morcury & $U \cdot 1.4$ & Nitate/Nitrite & $U .4 .3$ \\
\hline Nickel & $7.18 \cdot 18$ & Sulfate & 31.48 \\
\hline Potassium & $666 \mathrm{~B} \cdot 1360$ & \multicolumn{2}{|l|}{ VOAs (ug/kg) } \\
\hline Selonium & U.8 SN* & 2-Hexanone & $0.3 \mathrm{~J}$ \\
\hline Silver & $U \cdot 1.58$ & 2.Butanone & 0.148 \\
\hline Sodium & $1178 \cdot 1770$. & 4-Methyl-2-pentanone & $4.2 \mathrm{~J}$ \\
\hline Vanadium & $14.9 \cdot 55.8$ & Acetone & U. $3400 \mathrm{BE}$ \\
\hline Zne & $24.3 \cdot 49.5^{*}$ & Carbon disulfide & $0.11 \mathrm{~J}$ \\
\hline SEMIVVOAs (ug/kg) & & Chloroform & U.5 J \\
\hline Bis(2-othylhexyl)phthalate & U.99 B & Methylene chloride & $U .120$ \\
\hline Butylbenzylphthalate & U. $110 \mathrm{BS}$ & Toluene & U.BU \\
\hline Di-n-butyiphthalate & $\mathrm{U} .3200 \mathrm{BE}$ & & \\
\hline
\end{tabular}

B (norganics): Estimated value below contract required detection limit

$B$ (organics): Analyto detected in associated blank

N: Spiked sample recovery not within control limits

S: Dotormined by the Method of Standard Additions

$\because$ Ouplicate analysis not within control limits

E: Estimated value do to the presence of interference

J: Estimated value

$U$ : Undetectod 
DOE/RL-93-79, Rev. 0

Table 2-5 K Area LFI Volatile Organic Analyte Data Summary

(ug/L)

\begin{tabular}{|c|c|c|c|c|}
\hline Analyte & Max. Rep. Conc. & Well \# & Elim. & COPC \\
\hline 1,1,1-Trichloroethane & $U$ & NA & $x$ & \\
\hline 1,1,2,2-Tetrechlorocthane & U & NA & $\underline{x}$ & \\
\hline 1,1,2-Trichloroethane & $u$ & $N A$ & $x$ & \\
\hline 1,1-Dichloroothane & $u$ & NA & $x$ & \\
\hline 1,1-Dichloroethene & $u$ & NA & $x$ & \\
\hline 1,2-Dichloroothane & $u$ & NA & $\underline{x}$ & \\
\hline 1,2-Dichloroethene & $\underline{U}$ & NA & $x$ & \\
\hline 1,2-Dichloropropane & $u$ & NA & $x$ & \\
\hline 2-Butanone & $\underline{U}$ & NA & $\underline{x}$ & \\
\hline 2. Hexanone & $U$ & NA & $\underline{x}$ & \\
\hline 4-Mothyl-2.Pentanone & $u$ & NA & $\underline{x}$ & \\
\hline Acotone & U & NA & $x$ & \\
\hline Benzene & $u$ & NA & $x$ & \\
\hline Bromodichloromethane & U & NA & $x$ & \\
\hline Bromoform & $u$ & NA & $x$ & \\
\hline Bromomethane & $u$ & NA & $x$ & \\
\hline Carbon Disulfide & $\underline{U}$ & NA & $x$ & \\
\hline Carbon Totrachloride & $\underline{u}$ & NA & $\underline{x}$ & \\
\hline Chlorobenzene & U & NA & $x$ & \\
\hline Chloroethane & $\mathrm{U}$ & NA & $x$ & \\
\hline Chloroform & 17 & K-32A & & $\underline{x}$ \\
\hline Chloromothane & $U$ & NA & $x$ & \\
\hline cie-1,3-Dichloropropene & $U$ & NA & $x$ & \\
\hline Oibromochloromethane & $u$ & NA & $\underline{x}$ & \\
\hline Ethlybenzene & $U$ & NA & $x$ & \\
\hline Methylenochloride & $u$ & NA & $x$ & \\
\hline Styrene & U & NA & $\underline{x}$ & \\
\hline Totrachloroethene & $u$ & NA & $\underline{x}$ & \\
\hline Toluene & $\underline{U}$ & NA & $\underline{x}$ & \\
\hline trans-1,3-Oichloropropene & $u$ & NA & $x$ & \\
\hline Trichloroethene & 19 & K.33 & & $x$ \\
\hline Unyl Chloride & $u$ & NA & $x$ & \\
\hline xylenes (total) & $U$ & NA & $x$ & \\
\hline
\end{tabular}

U: Undetoctod

Na: Not applicable 
DOE/RL-93-79, Rev. 0

Table 2-6 K Area LFI Semi-Volatile Data Summary (page 1 of 2)

(ug/L)

\begin{tabular}{|c|c|c|c|c|}
\hline Analyo & Max. Aep. Conc. & Woll \# & Elim. & COPC \\
\hline Diethy phthalate & $U$ & NA & $x$ & \\
\hline 1,2,4 Trichlorobenzeno & $u$ & NA & $x$ & \\
\hline 1,2-Dlchlorobenzene & $u$ & NA & $x$ & \\
\hline 1,3-Dichlorobenzene & u & NA & $x$ & \\
\hline 1,4-Dichlorobenzene & $u$ & NA & $x$ & \\
\hline 2,4,5-Trichlorophenol & $u$ & NA & $x$ & \\
\hline 2,4,8-Trichlorophenol & u & NA & $x$ & \\
\hline 2.4Dichlorophenol & U & NA & $x$ & \\
\hline 2,4-Oimethylphenol & u & NA & $x$ & \\
\hline 2,4-Dinitrophenol & $u$ & NA & $x$ & \\
\hline 2,4-Oinitrotoluene & $\mathrm{u}$ & NA & $x$ & \\
\hline 2,6-Oinitrotoluene & $u$ & NA & $x$ & \\
\hline 2.Chloronaphthalene & $\underline{U}$ & NA & $x$ & \\
\hline 2-Chiorophenol & $u$ & NA & $x$ & \\
\hline 2.Mothyinaphthalene & $u$ & NA & $x$ & \\
\hline 2. Mothylghenol & $u$ & NA & $x$ & \\
\hline 2-Nitroaniline & u & NA & $x$ & \\
\hline 2-Nitrophenol & $u$ & NA & $x$ & \\
\hline 3,3-Oiehlorobenzidine & u & NA & $x$ & \\
\hline 3-Nitroaniline & U & NA & $x$ & \\
\hline 4,6-Dinitro-2-methylphenol & U & NA & $x$ & \\
\hline 4-Bromophenyiphenyl ether & $u$ & NA & $x$ & \\
\hline 4-Chloro-3-mothylphenol & $u$ & NA & $x$ & \\
\hline 4-Chloroaniline & $u$ & NA & $x$ & \\
\hline 4-Chlorophenylphenyl ether & $u$ & NA & $x$ & \\
\hline 4-Mothylphenol & $u$ & NA & $x$ & \\
\hline 4Nitroanilline & $u$ & NA & $x$ & \\
\hline 4-Nitrophenol & $u$ & NA & $x$ & \\
\hline 9H-Carbazole & $U$ & NA & $x$ & \\
\hline Acenaphthene & $u$ & NA & $x$ & \\
\hline Acenaphthyleno & U & NA & $x$ & \\
\hline Anthracene & u & NA & $x$ & \\
\hline Benzo(a)anthracene & $u$ & NA & $x$ & \\
\hline Benzo(a)pyrene & U & NA & $x$ & \\
\hline Benzo(b)fluoranthene & $u$ & NA & $x$ & \\
\hline Benzo(ghil)pendene & $u$ & NA & $x$ & \\
\hline Benzo(k)fluoranthene & $u$ & NA & $x$ & \\
\hline Bis(2-chloroothoxy)methane & $\underline{U}$ & NA & $x$ & \\
\hline Bis(2-chloroethy)other & $u$ & NA & $x$ & \\
\hline Bis(2-chloroisopropy) ether & U & NA & $x$ & \\
\hline Bis(2-thylhexyl)phthalate & $u^{*}$ & NA & $x$ & \\
\hline Butylbenzylphthalate & $u$ & NA & $x$ & \\
\hline Chryseno & u & NA & $x$ & \\
\hline Di-n-butylphthalate & U & NA & $x$ & \\
\hline Di-n-octydphthalate & $u$ & NA & $x$ & \\
\hline
\end{tabular}


DOE/RL-93-79, Rev. 0

Table 2-6 K Area LFI Semi-Volatile Data Summary (page 2 of 2)

(ug/L)

\begin{tabular}{|c|c|c|c|c|}
\hline Analyte & Max. Rep. Conc. & Woll * & Elim. & COPC \\
\hline Olbonzla,hlenthrecene & $u$ & NA & $x$ & \\
\hline Dibenzoturan & $u$ & NA & $x$ & \\
\hline OImothyphthalate & $u$ & NA & $x$ & \\
\hline Fluoranthene & $\underline{u}$ & $\mathrm{NA}$ & $x$ & \\
\hline Fluorene & $\underline{u}$ & NA & $x$ & \\
\hline Hoxechlorobenzene & $u$ & NA & $x$ & \\
\hline Hexachlorobutadiene & u & NA & $x$ & \\
\hline Hexechlorooyclopentadiene & $u$ & NA & $x$ & \\
\hline Hexechloroethane & $u$ & NA & $x$ & \\
\hline Indeno(1,2,3-ed)eyrene & $\underline{U}$ & NA & $x$ & \\
\hline leophorone & $u$ & NA & $x$ & \\
\hline N-nitroso-di-n-dipropylamine & $u$ & NA & $x$ & \\
\hline N-Nitrosodiphenylamine & $u$ & NA & $x$ & \\
\hline Naphthalene & $u$ & NA & $x$ & \\
\hline Nitrobenzene & $\underline{U}$ & NA & $\underline{x}$ & \\
\hline Pentachlorophenol & $u$ & NA & $x$ & \\
\hline Phenanthrene & U & NA & $x$ & \\
\hline Phenol & $u$ & NA & $x$ & \\
\hline Pyrene & $u$ & NA & $x$ & \\
\hline
\end{tabular}

U: Undetected

U*: Insufficent data to determine max. rep. conc.

Ands. 1 i 3 had eliminating equipment blanks

NA: Not applicable 
DOE/RL-93-79, Rev. 0

Table 2-7 K Area LFI Pesticide Data Summary

$(u g /$ L)

\begin{tabular}{|c|c|c|c|c|}
\hline Anclyte & Max. Aop. Conc. & Well " & Ellm. & COPC \\
\hline $4,4-000$ & $u$ & $M$ & $x$ & \\
\hline 4.A-DOE & $u$ & Na & $x$ & \\
\hline 4.4.00T & $u$ & NA & $x$ & \\
\hline Nodin & $u$ & $\mathrm{NA}$ & $x$ & \\
\hline Npha.BHC & $\underline{U}$ & NA & $x$ & \\
\hline Noha-chlordane & $u$ & NA & $x$ & \\
\hline Aroclor.1016 & $u$ & $\mathrm{NA}$ & $x$ & \\
\hline Noclor.1221 & $u$ & NA & $x$ & \\
\hline Noclor.1232 & $u$ & NA & $x$ & \\
\hline Aoclor. 1242 & $u$ & NA & $x$ & \\
\hline Noclor.1248 & $u$ & NA & $x$ & \\
\hline Noclor.1254 & $u$ & NA & $x$ & \\
\hline Avocior.1260 & $u$ & NA & $x$ & \\
\hline Bota-BHC & $u$ & NA & $x$ & \\
\hline Doha-BHC & $u$ & NA & $x$ & \\
\hline Dieldrin & $\underline{U}$ & NA & $x$ & \\
\hline Endosulian 1 & $\underline{U}$ & NA & $x$ & \\
\hline Endosultan II & $u$ & $\mathrm{NA}$ & $x$ & \\
\hline Endosulfan suliate & $u$ & NA & $x$ & \\
\hline Endrin & $u$ & NA & $x$ & \\
\hline Endrin Adohyde & $u$ & NA & $x$ & \\
\hline Endrin Ketone & $u$ & NA & $x$ & \\
\hline Gamma-BHC & $u$ & NA & $x$ & \\
\hline Gamma-chlordane & $U$ & NA & $x$ & \\
\hline Heptachlor & $u$ & NA & $x$ & \\
\hline Heptachlor epoxide & $\underline{U}$ & NA & $\underline{x}$ & \\
\hline Mothoxychlor & $u$ & NA & $x$ & \\
\hline Toxaphene & $u$ & NA & $x$ & \\
\hline
\end{tabular}

U: Undetected

NA. Not applicable 
DOE/RL-93-79, Rev. 0

Table 2-8 K Area LFI Radioisotopes Data Summary

$$
\text { (pCl/L) }
$$

\begin{tabular}{|c|c|c|c|c|c|c|}
\hline Analye & Max. Aep. Conc. & Woll * & Bkg. & > Bkg.? & Elim. & COPC \\
\hline Aneriolum.241 & $\mathrm{U}$ & $\mathrm{NA}$ & NA & NA & $x$ & \\
\hline Carbon.14 & 23000 & K.30 & NA & $\mathrm{NA}$ & & $x$ \\
\hline Coclum-134 & U & NA & NA & NA & $x$ & \\
\hline Ceslum.137 & $u$ & NA & NA & NA & $x$ & \\
\hline Chromium-s1 & $u$ & NA & NA & NA & $x$ & \\
\hline Cobalteo & $u$ & NA & NA & NA & $x$ & \\
\hline Europlum-152 & $u$ & NA & NA & NA & $x$ & \\
\hline Europium-154 & $\mathrm{U}$ & NA & NA & NA & $x$ & \\
\hline Gross Npha & 7.4 & K.27 & 5.79 & YES & & $\mathrm{NA}$ \\
\hline Grose Bota & 78 & K.34 & 12.82 & YES & & NA \\
\hline ron-39 & $\mathrm{u}$ & NA & NA & NA & $x$ & \\
\hline Plutonlum-238 & $U$ & NA & NA & NA & $x$ & \\
\hline Plutonium-239/240 & $U$ & NA & NA & NA & $x$ & \\
\hline Potaesium-40 & $\mathrm{U}$ & NA & NA & NA & $x$ & \\
\hline Pedium-220 & $u$ & NA & 0.23 & NA & $x$ & \\
\hline Authenium-106 & $u$ & NA & NA & NA & $x$ & \\
\hline Strontium-90 & 36 & $k-34$ & NA & NA & & $x$ \\
\hline Tochnotium-99 & 46 & K.27 & NA & NA & & $x$ \\
\hline Thorlum-228 & $u$ & NA & NA & NA & $x$ & \\
\hline Thorium-232 & $u$ & NA & NA & NA & $x$ & \\
\hline Tritium & 1900000 & K. 30 & NA & YES & & $x$ \\
\hline Uranium-233/234 & 3.3 & K-23 & \multirow{3}{*}{3.43} & YES & & $x$ \\
\hline Uranium-235 & 0.29 & K.27 & & YES & & $x$ \\
\hline Uranium-238 & 2.6 & K.23 & & YES & & $x$ \\
\hline Znc-65 & $u$ & NA & NA & NA & $x$ & \\
\hline
\end{tabular}

U: Undetected

NA: Not applicable 
DOE/RL-93-79, Rev. 0

Table 2-9 K Area LFI Wet Chemistry and Anions Data Summary

(mg/L)

\begin{tabular}{|c|c|c|c|c|c|c|}
\hline Analyte & Max. Rep. Conc. & Woll \# & Bkg. & > Bkg.? & Ellm. & COPC \\
\hline Nkalinity & 177 & K.23 & 210 & NO & $x$ & \\
\hline Ammonia & $u$ & NA & NA & $\mathrm{NA}$ & $x$ & \\
\hline Chloride & 21.0 & K-18 & 8.60 & YES & & $x$ \\
\hline Fuoride & 0.5 & $\mathrm{~K} \cdot 36$ & 0.775 & NO & $x$ & \\
\hline Nitrate/Nitrite-N & 28 & K.18 & 12.4 & YES & & $x$ \\
\hline Phosphate & U & NA & $<1$ & NA & $\underline{x}$ & \\
\hline Sultate & $109 \mathrm{~J}$ & $K-36$ & 90.5 & YES & & $x$ \\
\hline Sulfide & $u$ & NA & $\mathrm{NA}$ & NA & $x$ & \\
\hline
\end{tabular}

<: Reported value is the detection limit, value not used in screening

U: Undotocted

J: Estimated Value

NA: Not Applicable 
DOE/RL-93-79, Rev. 0

Table 2-10 K Area LFI Cation Data Summary

(ug/L)

\begin{tabular}{|c|c|c|c|c|c|c|c|}
\hline Analyte & Max. Rep. Conc. & Well \# & Non-Toxic? & Bkg. & $>$ Bkg.? & Elim. & COPC \\
\hline Numinum & $84 \mathrm{~J}^{*}$ & K-23 & YES & $<200$ & $\mathrm{NA}$ & $x$ & \\
\hline Antimony & $u$ & NA & NO & NA & $\mathrm{NA}$ & $x$ & \\
\hline Arenio & 10.4 & $k-11$ & NO & 10 & YES & & $x$ \\
\hline Barium & $61.8 \mathrm{~B}$ & K-34 & NO & 68.5 & NO & $x$ & \\
\hline Beryllium & $u$ & NA & No & $<5$ & NA & $x$ & \\
\hline Cadmium & $2.2 \mathrm{~B}$ & $K \cdot 18$ & NO & $<10$ & NA & & $x$ \\
\hline Calcium & 94600 & $k-33$ & YES & 63600 & YES & $x$ & \\
\hline Chromium & 1950 & K.36 & NO & $<30$ & NA & & $x$ \\
\hline Cobalt & 3.9 & K.23 & NO & NA & NA & & $x$ \\
\hline Copper & $U$ & NA & NA & $<30$ & NA & $x$ & \\
\hline Cyanide & $\underline{U}$ & NA & NA & NA & NA & $x$ & \\
\hline Iron & $5430 \mathrm{J"}$ & $k-23$ & YES & 291 & YES & $x$ & \\
\hline Lead & 7.6 & $k-11$ & NO & $<5$ & NA & & $x$ \\
\hline Magneslum & 17300 & K.23 & YES & 16480 & YES & $x$ & \\
\hline Manganose & 69.6 & K-21 & NO & 24.5 & YES & & $x$ \\
\hline Morcury & $u$ & NA & NA & $<0.1$ & NA & $x$ & \\
\hline Nickel & 18.7 & $K-11$ & NO & $<30$ & NA & & $x$ \\
\hline Potassium & 8510 & $K-23$ & YES & 7975 & YES & $x$ & \\
\hline Selenium & $U$ & NA & NO & $<5$ & NA & $x$ & \\
\hline Silver & 7.18 & $k-11$ & No & $<10$ & NA & & $x$ \\
\hline Sodium & 31100 & K.11 & YES & 33500 & No & $\underline{x}$ & \\
\hline Thallium & $U$ & NA & NO & NA & NA & $x$ & \\
\hline Vanadium & $23.8 \mathrm{~B}$ & $k-11$ & No & 15 & YES & & $x$ \\
\hline Zne & $461 \mathrm{E}$ & K.22 & No & $<50$ & NA & & $x$ \\
\hline
\end{tabular}

J: Estimated value

E: Estimated value

*: Duplicato analysis not within control limits

B: Value below the contract required detection limit

U: Undotocted

NA: Not applicable

$<$ : Reported value is the detection limit, value not used in screening 
DOE/RL-93-79, Rev. 0

Table 2-11 K Area LFI Near-River Volatile Organic Analyte Data Summary

(ug/L)

\begin{tabular}{|c|c|c|c|c|}
\hline Analyte & Max. Rep. Conc. & Well \# & Elim & COPC \\
\hline 1,1,1-Trichloroethano & $U$ & NA & $x$ & \\
\hline 1,1,2,2-Totrachloroothane & $u$ & $N A$ & $\underline{x}$ & \\
\hline 1,1,2-Trichloroethane & $u$ & NA & $x$ & \\
\hline 1,1-Dichloroothane & $\underline{U}$ & NA & $x$ & \\
\hline 1,1-Dichloroethene & $U$ & NA & $\underline{x}$ & \\
\hline 1,2-Dlchloroethane & $U$ & NA & $x$ & \\
\hline 1,2-Dichloroethene & $U$ & NA & $\underline{x}$ & \\
\hline 1,2-Dichloropropano & U & NA & $x$ & \\
\hline 2-Butanone & U & NA & $x$ & \\
\hline 2.Hexanone & $\underline{u}$ & NA & $\underline{x}$ & \\
\hline 4-Mothyl-2-Pentanone & $u$ & NA & $x$ & \\
\hline Acetone & $\underline{u}$ & NA & $x$ & \\
\hline Benzene & U & NA & $\underline{x}$ & \\
\hline Bromodichloromethane & u & NA & $\underline{x}$ & \\
\hline Bromoform & $U$ & NA & $\underline{x}$ & \\
\hline Bromomethane & $\underline{U}$ & NA & $\underline{x}$ & \\
\hline Carbon Disulfide & $U$ & NA & $x$ & \\
\hline Carbon Tetrachloride & U & NA & $x$ & \\
\hline Chlorobenzene & $u$ & NA & $x$ & \\
\hline Chloroethane & $U$ & NA & $x$ & \\
\hline Chloroform & 17 & $K-32 A$ & & $x$ \\
\hline Chloromethane & $\underline{U}$ & NA & $x$ & \\
\hline cis-1,3-Dichloropropene & $\mathrm{U}$ & NA & $x$ & \\
\hline Dibromochloromethane & $u$ & NA & $x$ & \\
\hline Ethlybenzene & $\underline{U}$ & NA & $x$ & \\
\hline Methylenechloride & U & NA & $x$ & \\
\hline Styrene & $u$ & NA & $x$ & \\
\hline Totrachloroethene & $u$ & NA & $\underline{x}$ & \\
\hline Toluene & $u$ & NA & $x$ & \\
\hline trans-1,3-Dichloropropene & $u$ & NA & $x$ & \\
\hline Trichloroethene & 19 & $K-33$ & & $\underline{x}$ \\
\hline Vinyl Chloride & $\underline{u}$ & NA & $x$ & \\
\hline Xylenes (total) & $u$ & NA & $x$ & \\
\hline
\end{tabular}

U: Undetected

NA: Not applicable 
DOE/RL-93-79, Rev. 0

Table 2-12 K Area LFI Near-River Semi-Volatiles Data Summary (page 1 of 2)

(ug/L)

\begin{tabular}{|c|c|c|c|c|}
\hline Analyte & Max. Rep. Conc. & Well \# & Elim. & COPC \\
\hline Diethyl phthalate & $U$ & NA & $x$ & \\
\hline 1,2,4-Trichlorobenzene & $\underline{U}$ & NA & $x$ & \\
\hline 1,2-Dichlorobenzene & $\underline{U}$ & NA & $x$ & \\
\hline 1,3-Dichlorobenzene & $u$ & NA & $x$ & \\
\hline 1,4-Oichlorobenzene & $\underline{U}$ & NA & $x$ & \\
\hline 2,2-Oxybis (1-chloropropano) & $u$ & NA & $x$ & \\
\hline 2,4,5-Trichlorophenol & $u$ & NA & $x$ & \\
\hline 2,4,6-Trichlorophenol & $u$ & NA & $x$ & \\
\hline 2,4-Dichlorophenol & $\underline{U}$ & NA & $x$ & \\
\hline 2,4-Dimethylphenol & $u$ & NA & $x$ & \\
\hline 2,4-Dinitrophenol & $U$ & NA & $x$ & \\
\hline 2,4-Dinitrotoluene & $u$ & NA & $x$ & \\
\hline 2,6-Dinitrotoluene & U & NA & $\underline{x}$ & \\
\hline 2-Chloronaphthalene & $u$ & NA & $x$ & \\
\hline 2-Chlorophenol & u & NA & $x$ & \\
\hline 2-Mothyinaphthalene & $u$ & NA & $\mathbf{x}$ & \\
\hline 2-Mothylphonol & U & NA & $x$ & \\
\hline 2-Nitroaniline & $U$ & NA & $x$ & \\
\hline 2-Nitrophenol & $\underline{U}$ & NA & $x$ & \\
\hline 3,3'-Dichlorobenzidine & $U$ & NA & $x$ & \\
\hline 3-Nittoaniline & $u$ & NA & $x$ & \\
\hline 4,6-Dinitro-2-methylphenol & $u$ & NA & $x$ & \\
\hline 4-Bromophenyiphenyl ether & $\underline{u}$ & NA & $x$ & \\
\hline 4-Chloro-3-methylphenol & $u$ & NA & $x$ & \\
\hline 4-Chloroaniline & 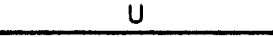 & NA & $x$ & \\
\hline 4-Chlorophenylphenyl other & $\underline{U}$ & NA & $x$ & \\
\hline 4-Methylphenol & U & NA & $x$ & \\
\hline 4-Nitroaniling & $u$ & NA & $x$ & \\
\hline 4-Nitrophenol & $u$ & NA & $x$ & \\
\hline Carbazole & $u$ & NA & $x$ & \\
\hline Acenaphthene & $\underline{U}$ & NA & $x$ & \\
\hline Acenaphthylene & $u$ & NA & $x$ & \\
\hline Anthracene & $\underline{u}$ & NA & $\underline{x}$ & \\
\hline Benzo(a)anthracene & $u$ & NA & $x$ & \\
\hline Benzo(a)pyrene & $\underline{U}$ & NA & $x$ & \\
\hline Benzo(b)fluoranthene & $\mathrm{u}$ & NA & $x$ & \\
\hline Benzo(ghi)perylene & $u$ & NA & $x$ & \\
\hline Benzo(k)fluoranthene & $\underline{u}$ & NA & $x$ & \\
\hline Bis(2-chloroethoxy)mothane & $u$ & NA & $x$ & \\
\hline Bis(2-chloroethy) ether & $\underline{U}$ & NA & $x$ & \\
\hline Bis(2-chloroisopropyl)ether & $\mathrm{u}$ & NA & $x$ & \\
\hline Bis (2-othylhexyl)phthalate & $u$ & NA & $x$ & \\
\hline Butylbenzylphthalate & $u^{*}$ & NA & $x$ & \\
\hline Chrysene & $\underline{U}$ & NA & $x$ & \\
\hline Di-n-butylphthalate & $u$ & NA & $x$ & \\
\hline
\end{tabular}


DOE/RL-93-79, Rev. 0

Table 2-12 K Area LFI Near-River Semi-Volatiles Data Summary (page 2 of 2)

(ug/L)

\begin{tabular}{|c|c|c|c|c|}
\hline Analyte & Max. Rep. Conc. & Well \# & Elim. & COPC \\
\hline Di-n-octylphthaiate & $U$ & NA & $x$ & \\
\hline Dibenz[a,h]anthracene & $u$ & $\overline{N A}$ & $\bar{x}$ & \\
\hline Dibenzofuran & $u$ & NA & $x$ & \\
\hline Dimothyphthalate & $U$ & NA & $x$ & \\
\hline Fuoranthone & $u$ & NA & $x$ & \\
\hline Fluorene & $U$ & NA & $x$ & \\
\hline Hexachlorobenzeno & $U$ & NA & $x$ & \\
\hline Hexachlorobutadiene & $u$ & NA & $x$ & \\
\hline Hexachlorocyclopentadiene & $u$ & NA & $x$ & \\
\hline Hoxachloroethane & $u$ & NA & $x$ & \\
\hline Indeno(1,2,3-cd)pyrene & $u$ & NA & $\bar{x}$ & \\
\hline lsophorone & $U$ & NA & $x$ & \\
\hline N-nitroso-di-n-dipropylamine & $u$ & NA & $x$ & \\
\hline N-Nitrosodiphenylamine & $u$ & NA & $x$ & \\
\hline Naphthalone & $U$ & NA & $x$ & \\
\hline Nitrobenzene & $U$ & NA & $x$ & \\
\hline Pentachlorophenol & $U$ & NA & $x$ & \\
\hline Phonanthrene & $u$ & NA & $x$ & \\
\hline Phenol & $U$ & NA & $x$ & \\
\hline Pyrene & $u$ & NA & $x$ & \\
\hline
\end{tabular}

U: Undetected

$U^{*}$ : Insufficent data to determine max. rep.conc.,

Pnds. 1 \& 3 had eliminating equipment blanks

NA: Not applicable 
DOE/RL-93-79, Rev. 0

Table 2-13 K Area LFI Near-River Pesticides Data Summary

(ug/L)

\begin{tabular}{|c|c|c|c|c|}
\hline Analvite & Max. Rep. Conc. & Well \# & Elim. & COPC \\
\hline $4,4 \div-000$ & $U$ & NA & $x$ & \\
\hline 4,4-DDE & $u$ & NA & $x$ & \\
\hline 4,4-DOT & $u$ & $\mathrm{NA}$ & $x$ & \\
\hline Ndrin & $u$ & NA & $x$ & \\
\hline Npha-BHC & $u$ & NA & $x$ & \\
\hline Apha-chlordane & $u$ & NA & $x$ & \\
\hline Aroclor-1016 & $u$ & NA & $x$ & \\
\hline Arocior-1221 & $u$ & $\mathrm{NA}$ & $x$ & \\
\hline Aroclor-1232 & $u$ & NA & $x$ & \\
\hline Avoclor. 1242 & $u$ & NA & $x$ & \\
\hline Aroclor-1248 & $u$ & NA & $x$ & \\
\hline Aroclor-1254 & $u$ & NA & $x$ & \\
\hline Aroclor-1260 & U & NA & $x$ & \\
\hline Bota-BHC & $U$ & NA & $x$ & \\
\hline Dolta-BHC & $U$ & NA & $x$ & \\
\hline Dieldrin & $u$ & NA & $x$ & \\
\hline Endosulfan I & $u$ & NA & $x$ & \\
\hline Endosultan II & $u$ & NA & $x$ & \\
\hline Endosulfan sulfate & $U$ & NA & $x$ & \\
\hline Endrin & $u$ & NA & $x$ & \\
\hline Endrin Adehyde & u & NA & $x$ & \\
\hline Endrin Ketone & $u$ & NA & $x$ & \\
\hline Gamma-BHC & $u$ & NA & $x$ & \\
\hline Gamme-chlordane & U & NA & $x$ & \\
\hline Heptachlor & $u$ & NA & $x$ & \\
\hline Hoptachlor opoxide & $U$ & NA & $x$ & \\
\hline Mothoxychler & $\bar{U}$ & NA & $x$ & \\
\hline Toxaphene & $U$ & NA & $x$ & \\
\hline
\end{tabular}

U: Undetected

NA: Not applicable 
DOE/RL-93-79, Rev. 0

Table 2-14 K Area LFI Near-River Wet Chemistry and Anions Data Summary

(mg/L)

\begin{tabular}{|c|c|c|c|c|c|c|}
\hline Analyto & Max. Rep. Conc. & Well \# & Bkg. & >Bkg.? & Elim. & COPC \\
\hline Nkalinity & 170 & $K-34$ & 210 & NO & $x$ & \\
\hline Ammonia & $U$ & NA & NA & NA & $x$ & \\
\hline Chloride & 21.6 & $K-18$ & 8.69 & YES & & $x$ \\
\hline Fluoride & 0.4 & K-31 & 0.775 & NO & $x$ & \\
\hline Nitrate/Nitrito-N & 26 & $K-18$ & 12.4 & YES & & $x$ \\
\hline Phosphate & $u$ & NA & $<1$ & $\mathrm{NA}$ & $x$ & \\
\hline Sulfate & 85.2 & K.33 & 90.5 & NO & $x$ & \\
\hline Sulfide & $U$ & NA & NA & NA & $x$ & \\
\hline
\end{tabular}
<: Reported value is the detection limit, value not used in screening
U: Undetected
NA. Not Applicable 
DOE/RL-93-79, Rev. 0

Table 2-15 K Area LFI Near-River Cation Data Summary

(ug/L)

\begin{tabular}{|c|c|c|c|c|c|c|}
\hline Analyte & Max. Rep. Conc. & Well \# & Bkq. & $>$ Bkg.? & Ellm. & COPC \\
\hline Numinum & 72.18 & K-18 & $<200$ & $\mathrm{NA}$ & & $x$ \\
\hline Antimony & $U$ & NA & $\mathrm{NA}$ & NA & $x$ & \\
\hline Areonic & $6.6 \mathrm{~B}$ & $K-13$ & 10 & NO & $x$ & \\
\hline Barium & $61.8 \mathrm{~B}$ & $K \cdot 34$ & 68.5 & NO & $x$ & \\
\hline Beryllium & $u$ & NA & $<5$ & NA & $x$ & \\
\hline Cadmium & $2.2 \mathrm{~B}$ & $K-18$ & $<10$ & NA & & $x$ \\
\hline Calcium & 94600 & K.33 & 63600 & YES & & $x$ \\
\hline Chromium & 261 & K.20 & $<30$ & NA & & $x$ \\
\hline Cobalt & $U$ & NA & NA & NA & $x$ & \\
\hline Copper & $U$ & NA & $<30$ & NA & $x$ & \\
\hline Cyanide & $U$ & NA & NA & NA & $x$ & \\
\hline ron & 1230 & $K \cdot 18$ & 291 & YES & & $x$ \\
\hline Loed & $5.8 \mathrm{WJ}$ & K-32A & $<5$ & NA & & $x$ \\
\hline Magnesium & 12100 & $k-13$ & 16480 & NO & $x$ & \\
\hline Manganese & 69.6 & K-21 & 24.5 & YES & & $x$ \\
\hline Moreury & $u$ & NA & $<0.1$ & NA & $x$ & \\
\hline Nickel & 9.9 & $K \cdot 18$ & $<30$ & NA & & $x$ \\
\hline Potassium & 6400 & $K-13$ & 7975 & No & $x$ & \\
\hline Selenium & $u$ & NA & $<5$ & NA & $x$ & \\
\hline Silver & $5.2 \mathrm{~B}$ & K.21 & $<10$ & NA & & $x$ \\
\hline Sodium & 20300 & $K-34$ & 33500 & No & $x$ & \\
\hline Thallium & $U$ & NA & NA & NA & $x$ & \\
\hline Vanadium & $19.1 \mathrm{~B}$ & $k-13$ & 15 & YES & & $x$ \\
\hline Znc & $461 E$ & K-22 & $<50$ & NA & & $x$ \\
\hline
\end{tabular}

E: Estimated value

B: Value below the contract required detection limit

U: Undetected

NA: Not applicable

<: Reported value is the detection limit, value not used in screening

J: Estimated value

W: Out of control limits 
DOE/RL-93-79, Rev. 0

Table 2-16 K Area LFI Near-River Radioisotopes

$(\mathrm{pCl} / \mathrm{L})$

\begin{tabular}{|c|c|c|c|c|c|c|}
\hline Anolyte & Max. Rep. Conc. & Well \# & Bkg. & > Bkg.? & Ellm. & COPC \\
\hline Amerielum-241 & U & NA & NA & $\mathrm{NA}$ & $x$ & \\
\hline Carbon-14 & 16000 & $K-33$ & NA & MA & & $x$ \\
\hline Corlum-144 & $U$ & NA & NA & $\mathrm{NA}$ & $x$ & \\
\hline Cosium-134 & $u$ & NA & $\mathrm{NA}$ & NA & $x$ & \\
\hline Cosium-137 & $u$ & NA & NA & NA & $\bar{x}$ & \\
\hline Chromiun-51 & $U$ & NA & NA & $\mathrm{NA}$ & $x$ & \\
\hline Cobaliteo & $U$ & NA & NA & $\mathrm{NA}$ & $x$ & \\
\hline Europlum-132 & U & NA & $\mathrm{NA}$ & NA & $x$ & \\
\hline Europium-154 & $u$ & NA & NA & $\mathrm{NA}$ & $x$ & \\
\hline Gross Nphe & 2.7 & K-37 & 5.79 & NO & $x$ & \\
\hline Groses Bota & 78 & $K-34$ & 12.62 & YES & & NA \\
\hline ron-50 & $u$ & NA & NA & NA & $x$ & \\
\hline Plutonlum-238 & $\bar{u}$ & NA & NA & $\overline{N A}$ & $x$ & \\
\hline Plutonium-239/240 & $u$ & NA & NA & NA & $x$ & \\
\hline Potassium-40 & $u$ & NA & NA & $\overline{N A}$ & $\bar{x}$ & \\
\hline Radium-228 & $u$ & NA & 0.23 & NA & $x$ & \\
\hline Authonium-108 & $u$ & NA & $\mathrm{NA}$ & NA & $x$ & \\
\hline Strontium-90 & 36 & K.34 & NA & NA & & $x$ \\
\hline Technetium-99 & $11 R$ & K-32A & NA & NA & & $x$ \\
\hline Thorium-228 & $u$ & NA & NA & NA & $x$ & \\
\hline Thorium-232 & $u$ & NA & NA & NA & $x$ & \\
\hline Tritium & 35000 & $K-33$ & NA & NA & & $x$ \\
\hline Uranium-233/234 & 2.3 & $K-34$ & \multirow{3}{*}{3.43} & YES & & $\bar{x}$ \\
\hline Uranium-235 & $0.16 \mathrm{~J}$ & K-34 & & YES & & $x$ \\
\hline Uranium-238 & 1.9 & $K \cdot 33$ & & YES & & $x$ \\
\hline Znc-65 & $u$ & NA & NA & NA & $x$ & \\
\hline
\end{tabular}

R: Rojected by validation report for adminisirative problems

J: Eatimated value

U: Undetected

NA. Not applicable 


\subsection{QUALITATIVE RISK ASSESSMENT}

The QRA for the 100-KR-4 Operable Unit is an evaluation of risk for a predefined set of human and environmental exposure scenarios. The QRA is not intended to replace or be a substitute for a baseline risk assessment. This report includes qualitative assessments of threats to human and ecological receptors from groundwater associated with the 100-KR-4 Operable Unit. The QRA is prepared using a common 100 Area approach as agreed on by the 100 Area Tri-Party Agreement unit managers, and as recommended in the HSBRAM (DOE-RL 1993c). This chapter provides a summary of the QRA and uncertainties associated with the results of the QRA (WHC 1993e).

\subsection{SUMMARY OF DATA USED}

The COPC (maximum representative groundwater concentrations) for the human health evaluation were selected from analyses of unfiltered samples from wells completed in the upper, unconfined aquifer of the 100-KR-4 Operable Unit. However, since human exposure to contaminants detected in the groundwater is most likely to occur to site trespassers at the river edge, concentrations of contaminants in the spring and the river also are reviewed (Table 3-1). In most cases, the spring and river water concentrations are either below maximum representative groundwater concentrations or below background levels.

The maximum representative groundwater concentrations of cuntaminants from unfiltered samples collected from near-river wells completed in the upper, unconfined aquifer of the 100-KR-4 Operable Unit were used for the ecological evaluation. The ecological evaluation consists of an evaluation of the near-river portion of the 100-KR-4 Operable Unit, and a review of contaminant concentrations in the springs and river.

\subsection{HUMAN HEALTH EVALUATION}

The QRA provides estimates of risk that might occur under frequent- or occasional-use scenarios based on the best available knowledge of current contaminant conditions.

\subsubsection{Overview of Human Health Evaluation Process}

Two exposure scenarios (frequent- and occasional-use) and two pathways (groundwater ingestion of contaminants and inhalation of volatile organics from groundwater use) have been discussed and selected by the 100 Area Tri-Party Agreement unit managers for evaluation in the QRA. The frequent- and occasional-use scenarios were evaluated using residential and recreational exposure parameters from HSBRAM (DOE-RL 1993c), respectively. Currently, there is no human consumption of groundwater in the 100-KR-4 Operable Unit. The human health evaluation also included a qualitative analysis of the most probable exposure scenario (occasional-use of springs by trespassers near the river). 
The ingestion pathway was evaluated for both frequent- and occasional-use scenarios. The inhalation pathway was only evaluated in the frequent-use scenario because it is assumed that exposures to volatile organic compounds would be most significant within the confines of a residence. Other exposure pathways were discussed qualitatively, but actual risks were not calculated.

\subsubsection{Summary and Conclusions}

The risk assessment results for the COPC for human health are summarized in Tables 3-2 and 3-3. Table 3-2 presents a list of COPC in descending order of the noncarcinogenic hazard quotient (HQ), and Table 3-3 presents a list of COPC in descending order of carcinogenic risk. The contaminant ranking in these tables is based on the results of assessment using the frequent-use scenario.

3.2.2.1 Noncarcinogenic Hazard. Table 3-2 summarizes the noncarcinogenic hazard for both frequent- and occasional-use scenarios and includes:

- an ordered list of the COPC

- an indication of whether the HQ exceeded 1.0

- percent of total hazard index (HI) (sum over contaminants of the HQ) contributed by the contaminant

- cumulative percent of total $\mathrm{HI}$ contributed by the contaminants.

Three COPC for noncarcinogenic risk (arsenic, chromium, and nitrate/nitrite) have HQ that exceed 1.0 under the frequent-use scenario. For all COPC, the HQ is $<1.0$ under the occasional-use scenario.

3.2.2.2 Carcinogenic Risk. Table 3-3 summarizes the carcinogenic risk for both frequentand occasional-use scenarios and includes:

- an ordered list of the COPC

- a qualitative risk estimation

- percent of total risk contributed by the contaminant

- cumulative percent of total risk contributed by the contaminants.

The qualitative risk estimations presented in Table 3-3 are assigned levels of high (incremental cancer risk [ICR] $\geq 1 \mathrm{E}-02)$, medium (1E-04 $\leq$ ICR $<1 \mathrm{E}-02)$, low (1E-06 $\leq$ ICR < 1E-04), and very low (ICR < IE-06), based on the results presented in Chapter 3 of the QRA. In general, the risk is two orders of magnitude (one level) lower for occasional-use than for frequent-use. This is true because the only difference in the risk calculations is the intake, and the only difference in the intake is the exposure frequency ${ }^{-}$ ( 7 days/year for occasional-use versus 365 days/year for frequent-use). This difference holds except when a contaminant has both an oral and an inhalation slope factor. If this is the 
case, the risk is summed across pathways for the frequent-use scenario, but only the ingestion risk applies for the occasional-use scenario.

There are $10 \mathrm{COPC}$ for carcinogenic risk. Under the frequent-use scenario, the total risk is medium. Three contaminants (arsenic, tritium and carbon-14) have medium risk estimations. The risk estimate for six contaminants (chloroform, trichloroethene, strontium-90, technetium-99, uranium-233/234 and uranium-238) is low. The risk estimate for uranium-235 is very low.

The total risk under the occasional-use scenario is low. The risk for the top three contaminants (arsenic, tritium, and carbon-14) is low, and the risk for the remaining contaminants is very low.

\subsubsection{Risk From Background Levels of COPC}

Hanford Site Baseline Risk Assessment Methodology (DOE-RL 1993c) prescribes that the risk from background concentrations of contaminants of concern be addressed in characterizing risk. The only COPC that have both background values and reference doses (RfD) for noncarcinogenic hazard assessment are arsenic, manganese, nitrate/nitrite and vanadium. Under the frequent-use scenario, only the HQ for arsenic exceeds 1.0. The HQ are $<1.0$ for all contaminants under the occasional-use scenario.

An evaluation was done for the carcinogenic contaminants of concern to determine the risk associated with the levels of the contaminant background concentrations. Only arsenic and total uranium have both background values and slope factors. The risk estimate for arsenic background is $>10^{-6}$ for both frequent- and occasional-use scenarios. There is a medium risk under the frequent-use scenario and a low risk under the occasional-use scenario. The risk for total uranium is low under the frequent-use scenario and is very low under the occasional-use scenario.

\subsection{ECOLOGICAL EVALUATION}

The following section provides an overview, results, and the key uncertainties for the ecological evaluation. The objective of the ecological evaluation is to screen for relative risks and evaluate whether an IRM is necessary from an ecological perspective.

\subsubsection{Overview of Ecological Evaluation Process}

The ecological evaluation consists of a problem formulation, analysis, and the risk characterization. It provides estimates of risk that might occur to ecological receptors exposed to contaminants discharged to the Columbia River from groundwater at the 100-KR-4 Operable Unit. 
3.3.1.1 Problem Formulation. The objective of the problem formulation phase is to demonstrate an understanding of the movement of stressors (contaminants) through the food chain and define the receptors likely to be impacted. It defines the stressors and their environmental characteristics, ecosystems potentially at risk, potential ecological effects and endpoints, and develops the conceptual model. Receptors selected for analysis in the QRA were some of the aquatic and riparian organisms expected to be in or associated with the Columbia River. To achieve the objective of the QRA, it was necessary to perform the assessment with limited operable unit-specific analytical and ecological data.

3.3.1.2 Analysis. The analysis phase is an evaluation of the data for the potential receptor response to stressors. Ecological profiles describing the general effects of the stressors are provided in Appendix B of the QRA (WHC 1993e).

3.3.1.3 Ecological Risk Characterization. The likelihood of an adverse effect is expressed in the form of an environmental hazard quotient (EHQ). The EHQ is defined as the ratio of the contaminant dose to some benchmark dose or criterion, as follows:

$$
\mathrm{EHQ}=\frac{\text { Organism's Dose }}{\text { Benchmark Dose }}
$$

The benchmark dose for radionuclides is defined by DOE Order 5400.5 (DOE 1989) as $1 \mathrm{rad} /$ day. Criteria for nonradiological contaminants were obtained from lowest observed effect levels (LOEL).

Two approaches were utilized to characterize the risks for the $100-\mathrm{KR}-4$ Groundwater Operable Unit. The first used the CRITR2 computer model to develop radiological dose rates to ducks and a plant, fish, crustacean, and heron. Receptor dose to nonradioactive contaminants was derived using ambient water quality criteria (EPA 1986).

\subsubsection{Summary and Conclusions}

The 100-KR-4 Operable Unit is a groundwater unit, which potentially affects the Columbia River. There is only one CERCLA equivalent sampling round of data for the $K$ Area springs and Columbia River, so these data are not used directly in the ecological QRA, but are presented for comparison purposes. Source term information was developed from near-river groundwater well constituent concentrations. The groundwater concentrations establish a set of bounding exposure scenarios for the organisms that were analyzed.

It is assumed that the values from near-river wells represent concentrations discharging through the $K$ Area springs and then to the Columbia River. In the $K$ Area springs, concentrations are below the LOEL, except for aluminum, chromium, and silver; the concentration of lead in the river was not available. Aluminum detected in springs may be caused by the spring water sample collection method that resulted in high alumina particles in the unfiltered samples. Once contaminants enter the Columbia River, dilution should result in rapid reduction of the concentrations to levels below any possible risk level. This appears to be the case, even for aluminum, chromium and silver which were not 
detected in the Columbia River. As a point of comparison, Table 3-1 presents the concentrations of the COPC for the groundwater wells, the near-river wells, the K Area springs, and the Columbia River near the $\mathrm{K}$ Area.

3.3.2.1 Radionuclide Hazard. Radionuclide doses were calculated for the selected organisms in the Columbia River and riparian zone. These organisms are aquatic plants, fish, crustacean, plant-eating duck, fish-eating duck, and heron. An EHQ was calculated using the benchmark of $1 \mathrm{rad} /$ day.

For all constituents evaluated, only carbon-14 exceeded an EHQ of 1.0. This occurs only for a single organism, the fish-eating duck. The resulting EHQ for the fish-eating duck are presented in Table 3-4. Although carbon-14 is a naturally occurring isotope, it is a COPC in the near-river wells. A background level for carbon-14 has not been established. Carbon-14 was not analyzed in samples taken from the $K$ Area springs and the Columbia River near the $\mathrm{K}$ Area.

3.3.2.2 Nonradionuclide Hazard. The ecological summary for nonradionuclides (hazardous chemicals), Table 3-5, indicates that the chronic EHQ based on near-river well concentrations were exceeded for cadmium, chromium, lead, silver, and zinc. Acute EHQ were exceeded for chromium, iron, silver and zinc. As is shown in the concentration summary table, Table 3-1, the concentrations of chromium, silver and zinc decrease significantly in the springs and river. However, the concentration of chromium found in the springs exceeds both the acute and chronic LOEL. The concentration of silver in the K Area springs is about the same as the concentration in the near-river wells, and this concentration exceeds only the chronic LOEL. Lead was not included in the analyses of the spring and river water samples. The primary concern posed by chromium in the $\mathrm{K}$ Area springs is that the 100 Area reach of the Columbia River is a known area of chinook salmon spawning, and if the groundwater concentrations exceed the acute and chronic LOEL for hexavalent chromium, there is an increased likelihood of risk to young chinook salmon and trout (Becker 1990).

\subsection{SUMMARY OF THE UNCERTAINTY IN THE QRA}

Uncertainty in the evaluation of data, human health risk, and ecological risk are discussed in this section.

\subsubsection{Uncertainty in the QRA Data}

The data used to conduct the QRA are LFI data from four rounds of sampling. Confidence levels are estimated for the data based on available knowledge of the waste site. Confidence in the contaminant identification is based primarily on the quality of the data used in the QRA. The confidence in the concentrations is based on the data quality and confidence in the representativeness of that data. Confidence levels used are high, medium, and low. 
A high confidence rating is given for contaminant identification at the $100-\mathrm{KR}-4$ Groundwater Operable Unit since the LFI data used in the QRA were collected specifically for characterization of the 100-KR-4 Operable Unit groundwater, and the data are of known quality. The confidence in the concentrations is given a high rating as well because data from four sampling rounds were used. A low confidence rating was given to the spring and river data because of the highly variable nature of the river/spring interactions.

There is uncertainty associated with the identification of chloroform and arsenic as COPC. Chloroform is considered a common laboratory contaminant, and it is likely that the concentrations reported for this compound are not representative of 100-KR-4 groundwater. Arsenic was not used in Hanford processes. Therefore, the risks associated with arsenic are likely related to background.

In general, the use of maximum concentrations to calculate risk for the QRA may result in an over-estimation of risk. The data represents a snapshot of concentration at a given time. The concentrations will vary in a way which cannot be predicted without modeling. Also, the effect of the Columbia River on the groundwater concentrations at the $\mathrm{K}$ Area is not known.

\subsubsection{Uncertainty in the Human Health Evaluation}

The risk estimates, both carcinogenic and noncarcinogenic, presented in this QRA are deterministic estimates based on multiple uncertainties. Uncertainty is introduced at all stages of the human health QRA. The uncertainty of the data used in the QRA has already been discussed. Additional uncertainty is added in the exposure assessment, toxicity assessment, and risk characterization stages.

This report estimates risk that might occur under frequent-use (i.e., residential) or occasional-use (i.e., recreational) based on using a common approach throughout the 100 Areas, as agreed to by the 100 Area Tri-Party unit managers. While these risks are based on the best knowledge of current contaminant conditions, they do not represent actual risks since neither residential or recreational uses currently occur at the operable unit.

Uncertainty exists in the exposure assessments because they are presented as a bounding of potential exposures (i.e., high frequency use such as residential or low frequency use such as recreational). The receptors evaluated for the 100-KR-4 Operable Unit are based on current contaminant conditions. For some radionuclides, radioactive decay over time can significantly reduce the concentrations to which a receptor may be exposed.

Uncertainty is associated with the toxicity values and the toxicity information available to assess potential adverse effects. This uncertainty in the information and the lack of specific toxicity information contribute to uncertainty in the toxicity assessment. For non-radioactive contaminants identified at the 100-KR-4 Operable Unit, there is relatively good information for potential exposures through the oral route. However, toxicity values and information to evaluate the inhalation exposure route are more limited. 
Lead, although known to be quite toxic to sensitive individuals, does not have either a RfD or slope factor. Also, because the use of models in the QRA was limited, EPA's lead model was not applied. The concentrations of lead detected at the 100-KR-4 Operable Unit exceed both the EPA assigned maximum contaminant level goal (MCLG) of $0 \mathrm{mg} / \mathrm{L}$ (40 CFR 141), and the hardness-dependent criteria established for ecological effects of $0.0036 \mathrm{mg} / \mathrm{L}$ (EPA 1986).

Uncertainty exists as to whether chromium is in the hexavalent or trivalent state. Hexavalent chromium is assumed for the QRA because it provides the most conservative evaluation and was the form used (i.e., sodium dichromate) in some $100 \mathrm{~K}$ Area operations.

The estimated risks or HQ by themselves do not fully characterize the risk impacts associated with environmental contamination. Such an evaluation must be understood in light of the uncertainties presented above. The risk estimates are based on single point estimates from LFI data assuming two different sets of exposure assumptions (i.e., residential and recreational).

Uncertainty in the risk characterization results from summing cancer risks or HQ across contaminants and pathways which gives equal weight to toxicity information derived from different sources or species. Exposure to multiple contaminants may result in additive effects or effects that are greater or less than additive.

\subsubsection{Uncertainty in the Ecological Evaluation}

The ecological evaluation depicts the potential exposure of select wildlife to contaminants present in groundwater near the river. This creates two primary uncertainties for the ecological evaluation, the source term and the conceptual model. The concern begins with source term. If this number is not realistic, no amount of modeling will overcome this deficiency. In the case of the ecological evaluation, the maximum representative reported groundwater concentration was used as the source term and no river dilution was considered.

The next issue is that the organisms used in the evaluation do not represent the river's entire ecosystem. However, this limited conceptual model was agreed on by the Tri-Party Agreement unit managers as a sufficient scenario for an IRM decision (February 8, 1992).

Additional uncertainties associated with wildlife toxicity values also are significant. Benchmark toxicity values for nonradiological contaminants (LOEL) were developed from laboratory tests and extrapolated to the environment. The effects of chronic exposure of organisms to radionuclides are not known. At low dose levels organisms can repair some damage to correct for radiological dose. However, dose/response relationships were developed at acute levels and extrapolated to chronic levels. In addition, no regulatory benchmark exists for radionuclides other than the $1 \mathrm{rad} /$ day issued by DOE Order 5400.5.

Risk is expressed as an EHQ, which implies a single conclusion has been reached. As discussed above, this quotient is the result of the interaction, uncertainty, and 
conservatism of many different factors that enter into the risk characterization. The environmental relevancy of the characterization depends on the accuracy of these factors.

\subsection{CONCLUSIONS OF QRA}

The QRA is used in the LFI process to (1) screen out contaminants from the remedial action list; and (2) assess the need for an IRM. The QRA results suggest that some unacceptable risks might exist from "exposure to groundwater" from the 100-KR-4 Operable Unit. While it is reasonable to use this condition to conservatively estimate the risks from contaminants, none of the estimated risks (human or ecological) are based on current exposure scenarios and future land-use for the site has not been determined.

The upper bound estimates of risk, even with the associated uncertainties, are sufficient to support an initial decision for the 100-KR-4 Operable Unit. The true risk from the groundwater at the $\mathrm{K}$ Area is most likely to be less than the risk presented in this QRA. 
DOE/RL-93-79, Rev. 0

Table 3-1 Comparison of Concentrations for Contaminants of Potential Concern

\begin{tabular}{|c|c|c|c|c|}
\hline & $\begin{array}{c}\text { All } \\
\text { Groundwater } \\
\text { Wells }\end{array}$ & $\begin{array}{c}\text { Near-Aiver } \\
\text { Groundwater } \\
\text { Wells }\end{array}$ & $\begin{array}{c}\text { K Area } \\
\text { Springs (a) }\end{array}$ & $\begin{array}{l}\text { K Area } \\
\text { Columbin } \\
\text { River (a) }\end{array}$ \\
\hline \multicolumn{5}{|c|}{ Organics (All Concentrations in ug/L) } \\
\hline Chloroform & 17 & 17 & NA & NA \\
\hline Trichloroethene & 19 & 19 & NA & NA \\
\hline \multicolumn{5}{|c|}{ Inorganics (All Concentrations in ug/ $L$, except as noted) } \\
\hline Aluminum & $844 \mathrm{~J}^{\star}$ & $72.1 \mathrm{~B}$ & 255 & ND \\
\hline Arsenic & 10.4 & $6.6 \mathrm{~B}$ & NA & NA \\
\hline Cadmium & $2.2 \mathrm{~B}$ & $2.2 \mathrm{~B}$ & ND & ND \\
\hline Chloride (mg/L) & 21.6 & 21.6 & 6.01 & 0.86 \\
\hline Chromium & 1950 & 261 & 68.7 & ND \\
\hline Iron & $5430 \mathrm{~J} *$ & 1230 & 243 & 171 \\
\hline Lead & 7.6 & $5.8 \mathrm{WJ}$ & NA & NA \\
\hline Manganese & 69.6 & 69.6 & ND & 19.6 \\
\hline Nickel & 18.7 & 9.9 & ND & ND \\
\hline Nitrate/Nitrite $(\mathrm{mg} / \mathrm{L})$ & 26 & 26 & 1.47 & 0.5 \\
\hline Silver & $7.1 \mathrm{~B}$ & $5.2 \mathrm{~B}$ & 5.5 & ND \\
\hline Total Dissolved Solids (mg/L) & 452 & 452 & 221 & 89 \\
\hline Vanadium & $23.8 \mathrm{~B}$ & $19.1 \mathrm{~B}$ & 10.7 & ND \\
\hline Zinc & $461 E$ & $461 E$ & ND & 6.4 \\
\hline \multicolumn{5}{|c|}{ Radionuclides (All Concentrations in $\mathrm{pCi} / \mathrm{L}$ ) } \\
\hline Carbon-14 & 23000 & 16000 & NA & NA \\
\hline Strontium-90 & 36 & 36 & 8.8 & 0.7 \\
\hline Tochnetium-99 & 46 & $11 \mathrm{R}$ & 5.2 & 2 \\
\hline Tritium & 1900000 & 35000 & 8900 & ND \\
\hline Uranium-233/234 & 3.3 & 2.3 & NA & NA \\
\hline Uranium-235 & 0.29 & $0.16 \mathrm{~J}$ & NA & NA \\
\hline Uranium-238 & 2.6 & 1.9 & NA & NA \\
\hline Total Uranium & NA & NA & 1.1 & 0.49 \\
\hline
\end{tabular}

ND - Not Detected

NA - No Data Available

(a) - Data from DOE/RL 1992c

$J$ - Estimated value

- Dupllcate analysis not within control limits

B - Value below the contract required detection limit

E - Estimated value

W - Out of control limits

$R$ - Rejected by validation report for administrative problems 
DOE/RL-93-79, Rev. 0

Table 3-2 Human Health Risk Summary, Noncarcinogenic Effects

\begin{tabular}{|c|c|c|c|c|c|c|}
\hline \multirow[b]{2}{*}{ Anaryte } & \multicolumn{3}{|c|}{ Occasional } & \multicolumn{3}{|c|}{ Frequent } \\
\hline & $\begin{array}{c}\text { Compartion } \\
\text { of to to } \\
1.0\end{array}$ & $\begin{array}{c}\text { Percent of } \\
\text { Total HI }\end{array}$ & $\begin{array}{c}\text { Cumulative } \\
\text { Percent of } \\
\text { Total HI }\end{array}$ & $\begin{array}{c}\text { Comparison } \\
\text { of HO to } \\
1.0\end{array}$ & $\begin{array}{c}\text { Percent of } \\
\text { Total HI }\end{array}$ & $\begin{array}{l}\text { Cumulative } \\
\text { Percent of } \\
\text { Total HI }\end{array}$ \\
\hline Chromium & BELOW & 83.2 & 83.2 & ABOVE & 83.4 & 83.4 \\
\hline Areonic & BELOW & 7.5 & so.7. & ABOVE & 7.4 & 90.8 \\
\hline Nitrate/Nitrite & BELOW & 3.4 & 94.1 & ABOVE & 3.5 & 94.3 \\
\hline Manganese & BELOW & 3.0 & 97.1 & BELOW & 3.0 & 97.3 \\
\hline Vanadium & BELOW & 0.7 & 97.5 & BELOW & 0.7 & 98.0 \\
\hline Trichloroethene & BELOW & 0.7 & 98.6 & BELOW & 0.7 & 98.7 \\
\hline Cadmium & BELOW & 0.5 & 99.1 & BELOW & 0.5 & 99.1 \\
\hline Chloroform & BELOW & 0.4 & 99.5 & BELOW & 0.3 & 99.5 \\
\hline Znc & BELOW & 0.4 & 99.8 & BELOW & 0.3 & 99.8 \\
\hline Numinum & BELOW & 0.2 & 100.0 & BELOW & 0.2 & 100.0 \\
\hline Iron & No Data & NA & & No Data & NA & \\
\hline Load & No Data & NA & & No Data & NA & \\
\hline
\end{tabular}


DOE/RL-93-79, Rev. J

Table 3-3 Human Health Risk Summary, Carcinogenic Effects

\begin{tabular}{|c|c|c|c|c|c|c|}
\hline \multirow[b]{2}{*}{ Analyto } & \multicolumn{3}{|c|}{ Occasional } & \multicolumn{3}{|c|}{ Frequent } \\
\hline & $\begin{array}{c}\text { Oualltattve } \\
\text { Rlak }\end{array}$ & $\begin{array}{l}\text { Porcent of } \\
\text { Total Risk }\end{array}$ & $\begin{array}{l}\text { Cumulative } \\
\text { Percent of } \\
\text { Total Risk }\end{array}$ & $\begin{array}{c}\text { Qualltatlve } \\
\text { Rlsk }\end{array}$ & $\begin{array}{l}\text { Porcent of } \\
\text { Total Rlsk }\end{array}$ & $\begin{array}{l}\text { Cumulatuve } \\
\text { Percent of } \\
\text { Total Rlak }\end{array}$ \\
\hline Tritlum & LOW & 76.1 & 76.1 & MEDIUM & 74.4 & 74.4 \\
\hline Carbon-14 & Low & 15.3 & 91.4 & MEDIUM & 15.0 & 89.4 \\
\hline Arsonic & LOW & 7.3 & 98.8 & MEDIUM & 7.1 & 96.8 \\
\hline Total Chloroform & VEAY LOW & $<0.1$ & 98.8 & LOW & 2.1 & 98.7 \\
\hline Strontium-90 & VERY LOW & 1.0 & 99.8 & LOW & 0.9 & 99.6 \\
\hline Total Trichloroethene & VERY LOW & 0.1 & 99.5 & LOW & 0.3 & 99.5 \\
\hline Uranium-238 & VERY LOW & $<0.1$ & 99.9 & LOW & 0.1 & 99.5 \\
\hline Technotium-99 & VERY LOW & $<0.1$ & 100.0 & LOW & $<0.1$ & 100.0 \\
\hline Uranium-233/234 & VERY LOW & $<0.1$ & 100.0 & LOW & $<0.1$ & 100.0 \\
\hline Uranium-235 & VERY LOW & $<0.1$ & 100.0 & VERY LOW & $<0.1$ & 100.0 \\
\hline Total Rlak & LOW & & & MEDIUM & & \\
\hline
\end{tabular}


DOE/RL-93-79, Rev. 0

Table 3-4 Ecological Summary for Radionuclides; Organism: Fish-Eating Duck

\begin{tabular}{|c|c|c|c|}
\hline \multirow[b]{2}{*}{ Analyto } & \multicolumn{3}{|c|}{ Mear-Rlver Groundwater Wells } \\
\hline & $\begin{array}{c}\text { Comparison to } \\
\text { EHO }=1.0\end{array}$ & $\begin{array}{l}\text { Percent of } \\
\text { Total EHO }\end{array}$ & $\begin{array}{l}\text { Cumulattve } \\
\text { Percent of } \\
\text { Total EHO }\end{array}$ \\
\hline Carbon-14 & ABOVE & 99.8 & 99.8 \\
\hline Strontlum- 80 & BELOW & 0.2 & 100.0 \\
\hline Uranium-233/234 & BELOW & $<0.1$ & 100.0 \\
\hline Tritium & BELOW & $<0.1$ & 100.0 \\
\hline Uranium-238 & BELOW & $<0.1$ & 100.0 \\
\hline Uranium-235 & BELOW & $<0.1$ & 100.0 \\
\hline Technitium-99 & BELOW & $<0.1$ & 100.0 \\
\hline
\end{tabular}


DOE/RL-93-79, Rev. 0

Table 3-5 Ecological Summary for Nonradionuclides

\begin{tabular}{|c|c|c|}
\hline & Near-Alver Grou & water Wells \\
\hline Anatye & $\begin{array}{c}\text { Comparison } \\
\text { 10 Acute } \\
\text { EHO=1.0 }\end{array}$ & $\begin{array}{c}\text { Comparison } \\
\text { to Chronle } \\
\text { EHQ } 1.0\end{array}$ \\
\hline Chromium & ABOVE & ABOVE \\
\hline Zne & ABOVE & ABOVE \\
\hline Iron & ABOVE & NA \\
\hline Silvor & BELOW & ABOVE \\
\hline Load & BELOW & ABOVE \\
\hline Auminum & BELOW & BELOW \\
\hline Cadmium & BELOW & BELOW \\
\hline Nickol & BELOW & BELOW \\
\hline Vanadium & BELOW & NA \\
\hline Chloroform & BELOW & BELOW \\
\hline Manganese & BELOW & NA \\
\hline Tricloroethene & NA & BELOW \\
\hline Chloride & $\mathrm{NA}$ & NA \\
\hline Nitrate/Nitrite & NA & NA \\
\hline Total Dissolved Solids & NA & NA \\
\hline
\end{tabular}

Na - No Data Available 


\subsection{CONTAMINANTS OF POTENTIAL CONCERN IN THE GROUNDWATER}

Groundwater chemistry data were obtained from analyses of samples collected from wells drilled under this LFI, wells drilled for specific facility monitoring and from pre-1991 wells determined to be "fit-for-use" as monitoring structures (Ledgerwood 1991). The following sections discuss the analytes which were detected through the LFI groundwater sampling and analysis effort and identified as COPC in the QRA. Analytes exceeding potential ARAR are also identified as COPC. Contaminants of potential concern were identified using four sampling rounds. Contaminants of potential concern were identified through the risk assessments, human-health and ecological, and by comparison against potential ARAR. The COPC, and the triggering criteria based on the four rounds of LFI sampling are shown in Table 4-1. No COPC were identified based on the occasional-use human health scenario. Under the frequent-use human health scenario, five COPC were identified: chromium, arsenic, nitrate/nitrite nitrogen, tritium and carbon-14. In addition, the ecological QRA identified zinc, iron, lead and silver as contaminants having EHQ $>1$. Under the exceedance of potential ARAR criterion, eleven COPC were identified: carbon-14, strontium-90, tritium, chloroform, trichloroethene, nitrate/nitrite, arsenic, cadmium, chromium, lead and manganese.

\subsection{CONTAMINANTS OF POTENTIAL CONCERN}

Five constituents were identified as COPC based on the frequent-use human-health risk assessment. The QRA identified arsenic, chromium and nitrate as noncarcinogenic risk drivers and arsenic, tritium, and carbon-14 as carcinogenic risk drivers. All constituents were either had HQ $<1$ or low risk in the occasional-use scenario analysis. The ecological risk assessment identified chromium, iron, lead, silver, zinc, and carbon-14 as COPC. Table 4-2 lists those constituents presenting either a human-health or ecological risk, by well and by sampling round.

\subsubsection{Chromium}

Chromium is present in the groundwater underlying most of the operable unit. The distribution of maximum concentrations determined for each well is shown in Figure 4-1. Four isolated yet distinct highs exist; one near each of the reactors, one near the KW Water Treatment Basins and the other near the 116-K-2 Trench. Highest concentrations are found in wells $199-\mathrm{K}-36(1950 \mu \mathrm{g} / \mathrm{L}), 199-\mathrm{K}-20(261 \mu \mathrm{g} / \mathrm{L}), 199-\mathrm{K}-34(136 \mu \mathrm{g} / \mathrm{L})$ and $199-\mathrm{K}-22$ $(183 \mu \mathrm{g} / \mathrm{L})$. 


\subsubsection{Arsenic}

Arsenic is present in many of the monitoring wells in the 100-KR-4 Operable Unit and ranges from nondetected to $10.4 \mu \mathrm{g} / \mathrm{L}$ in well $199-\mathrm{K}-11$. The distribution of maximum concentrations determined for each well is shown in Figure 4-2. Arsenic is present as a natural component of groundwater in the unconfined aquifer. There is no known Hanford Operations source for the arsenic found in the groundwater beneath the $100 \mathrm{~K}$ Area. While arsenic was a common constituent of pesticides used in orchards that once occupied Hanford, there are no preHanford orchards evident in the area.

\subsubsection{Cadmium}

Cadmium is present in groundwater of the 100-KR-4 Operable Unit. Reported concentrations of as high as $2.2 \mu \mathrm{g} / \mathrm{L}$ exceed the reported chronic or acute freshwater aquatic species requirements. There has been no reported disposal of cadmium contaminated wastes in the $100 \mathrm{~K}$ Area.

\subsubsection{Manganese}

Manganese is present in the $100-\mathrm{K}$ Area groundwater at concentrations of up to $69.6 \mu \mathrm{g} / \mathrm{L}$. Manganese is a common, naturally occurring constituent in surface and groundwater. It is likely that these concentrations are indicative of natural conditions.

\subsubsection{Nitrate/Nitrite}

Nitrate/nitrite analyses of groundwater show concentrations above the $10 \mu \mathrm{g} / \mathrm{L}$ potential ARAR. The primary component of the nitrate/nitrite analyses is nitrate. Nitrate is a common contaminant due to Hanford operations in addition to being a natural constituent. Likely sources of nitrate are the disposals of nitric acid containing solutions.

\subsubsection{Trichloroethene}

Trichloroethene is reported at a maximum concentration of $19 \mu \mathrm{g} / \mathrm{L}$ in well $199-\mathrm{K}-33$. This concentration is in excess of the minimum potential ARAR of $2.7 \mu \mathrm{g} / \mathrm{L}$.

Trichloroethene may have been used as a solvent at sometime during the $100 \mathrm{~K}$ Area's operating history. No significant human-health or ecological risk was attributed to this compound. 


\subsubsection{Chloroform}

Chloroform was reported in many analyses of $100-\mathrm{KR}-4$ groundwater. The maximum reported concentration was $17 \mu \mathrm{g} / \mathrm{L}$ in well 199-K-32A. These concentrations exceed the minimum potential ARAR concentration of $5.4 \mu \mathrm{g} / \mathrm{L}$. Chloroform is a common by product of water treatment by chlorination.

\subsubsection{Strontium-90}

Strontium-90 is present in numerous wells in excess of the potential ARAR mandated $8 \mathrm{pCi} / \mathrm{L}$. The maximum reported concentration in the $100 \mathrm{~K}$ Area is $36 \mathrm{pCi} / \mathrm{L}$ from well 199-K-34. Strontium-90 has been reported in vegetation growing along the Columbia River.

\subsubsection{Tritium}

Tritium is present at concentrations in excess of $1,500,000 \mathrm{pCi} / \mathrm{L}$ in the vicinity of the 105-KE Reactor (Figure 4-3). Wells $199-\mathrm{K}-27(140,000 \mathrm{pCi} / \mathrm{L})$ and $199-\mathrm{K}-30(1,900,000)$ are the only wells showing tritium above the $20,000 \mathrm{pCi} / \mathrm{L}$ drinking water standard. These wells are near the dry well associated with the inert gas recirculation system for the 105-KE Reactor where known disposal of tritiated water occurred. These wells are also near the fuel storage basins associated with that facility. These basins are suspected of having leaked contaminated water (DOE-RL 1992d) and are the subject of ongoing investigation. The distribution of maximum concentrations determined for each well is shown in Figure 4-3.

\subsubsection{Carbon-14}

Although is a naturally occurring radioisotope, carbon-14 is a contaminant centered around the $100 \mathrm{~K}$ reactors. The distribution of maximum concentrations determined for each well is shown in Figure 4-4. Concentrations of carbon-14 range from undetected to $23,000 \mathrm{pCi} / \mathrm{L}$. Maximum concentrations occur in the vicinity of two dry wells used to dispose of effluent from the 105-KW and 105-KE Gas Recirculation Buildings. The carbon-14 is believed to have been generated during the time nitrogen was used as the reactor inert-gas blanket. Carbon- 14 was not detected in the vicinity of the $116-\mathrm{K}-2$ Trench.

\subsubsection{Iron}

Iron was identified as an ecologically based contaminant of concern; concentrations exceed the acute LOEL. The maximum near-river well groundwater concentration was $1230 \mu \mathrm{g} / \mathrm{L}$. Iron is a common constituent of the soils that comprise the unconfined aquifer. Iron was carried forward because it is detected with consistency across the operable unit. 
DOE/RL-93-79, Rev. 0

\subsubsection{Lead}

Lead is identified as an ecologically based contaminant of concern as concentrations exceed the chronic LOEL. The maximum near-river well groundwater concentration was $5.8 \mu \mathrm{g} / \mathrm{L}$. Large quantities of lead were used as radiation shielding, but this lead was not in contact with the reactor's coolant stream.

\subsubsection{Zine}

Zinc is identified as an ecologically based contaminant of concern as concentrations exceed the acute LOEL. The maximum near-river well groundwater concentration was $461 \mu \mathrm{g} / \mathrm{L}$. Zinc is a commonly used metal plating material and readily enters the environment through oxidation.

\subsubsection{Silver}

Silver is identified as an ecologically based contaminant of concern as concentrations exceed the chronic LOEL. The maximum near-river well groundwater concentration was $5.2 \mu \mathrm{g} / \mathrm{L}$. There is no known source for the silver other than as a common constituent of the soils.

\subsection{CONFINED AQUIFER}

Confined aquifers in the 100-KR-4 Operable Unit are found in the Ringold Formation and within the CRBG. A limited number of wells in the 100 Area tap these confined units. Sand lenses in the upper portions of the Ringold Formation often act as semi-confined aquifers with vertical leakage occurring in either direction depending on interactions of the unconfined aquifer with the Columbia River. Water levels taken in paired wells 199-K-32A (shallow) and 199-K-32B (deep) show significant upward potential (78 ft) under all river stages. Heads increase with depth through the Ringold Formation and into the basalt aquifers of the CRBG. No contaminants were found in well 199-K-32B installed as part of the 100-KR-4 Operable Unit LFI. 


\subsection{POTENTIAL APPLICABLE OR RELEVANT AND APPROPRIATE REQUIREMENTS AND TO-BE-CONSIDERED GUIDANCE}

Potential chemical-specific ARAR for the 100-KR-4 Operable Unit are discussed in the following sections. Potential location-specific ARAR are identified in the 100 Area Feasibility Study Phases 1 and 2 (DOE-RL 1993a). These location-specific ARAR do not have associated chemical-specific concentrations.

Safe Drinking Water Act. The maximum contaminant levels (MCL) prescribed in EPA's National Primary Drinking Water Regulations' under the Safe Drinking Water Act are relevant and appropriate regulations for the 100-KR-4 Operable Unit. Secondary MCL are to-be-considered (TBC) per the National Contingency Plan (NCP). Title 40 Code of Federal Regulations (CFR) 141.16 limits the concentrations of photon and beta particle emitters to levels which would not exceed an annual dose equivalent to the total body or any internal organ of $4 \mathrm{mrem} / \mathrm{yr}$. This section also prescribes a methodology for calculating the concentration of radionuclides using a daily intake of $2 \mathrm{~L} /$ day and the 168 hour data listed in Maximum Permissible Body Burdens and Maximum Permissible Concentration of Radionuclides in Air or Water for Occupational Exposures (NBS 1963). Primary MCL, MCLG, and secondary MCL are listed in Table 4-2.

Model Toxics Control Act. The Model Toxics Control Act (MTCA) (WAC 173-340) defines ground and surface water standards for both residential and industrial scenarios. The MTCA does not include standards for radionuclides.

Additional ARAR and TBC guidelines are included in Table 4.2. The DOE Order 5400.5 establishes groundwater standards based on a $100 \mathrm{mrem} / \mathrm{yr}$ dose. Converting these standards to correspond to a $4 \mathrm{mrem} / \mathrm{yr}$ dose (by dividing by 25 ) results in the following levels:

\footnotetext{
- $\quad$ tritium $-80,000 \mathrm{pCi} / \mathrm{L}$

- carbon-14-2,800 pCi/L

- uranium $233 / 234-10,000 \mathrm{pCi} / \mathrm{L}$

- uranium-238 - $24 \mathrm{pCi} / \mathrm{L}$.
}

Tilfe 40 CFR as amended at S6 FR 32113. July 15, 1991; 57 FR 1852, January 15, 1992; 57 FR 22178, May 27. 1997: 47 FR 24747, June 10, 1992; 57 FR 28788, Jum 29, 1992; 57 FR 31838. July 17, !992 
DOE/RL-93-79, Rev. 0

Figure 41 Chromium Concentrations in the $100 \mathrm{~K}$ Area Groundwater

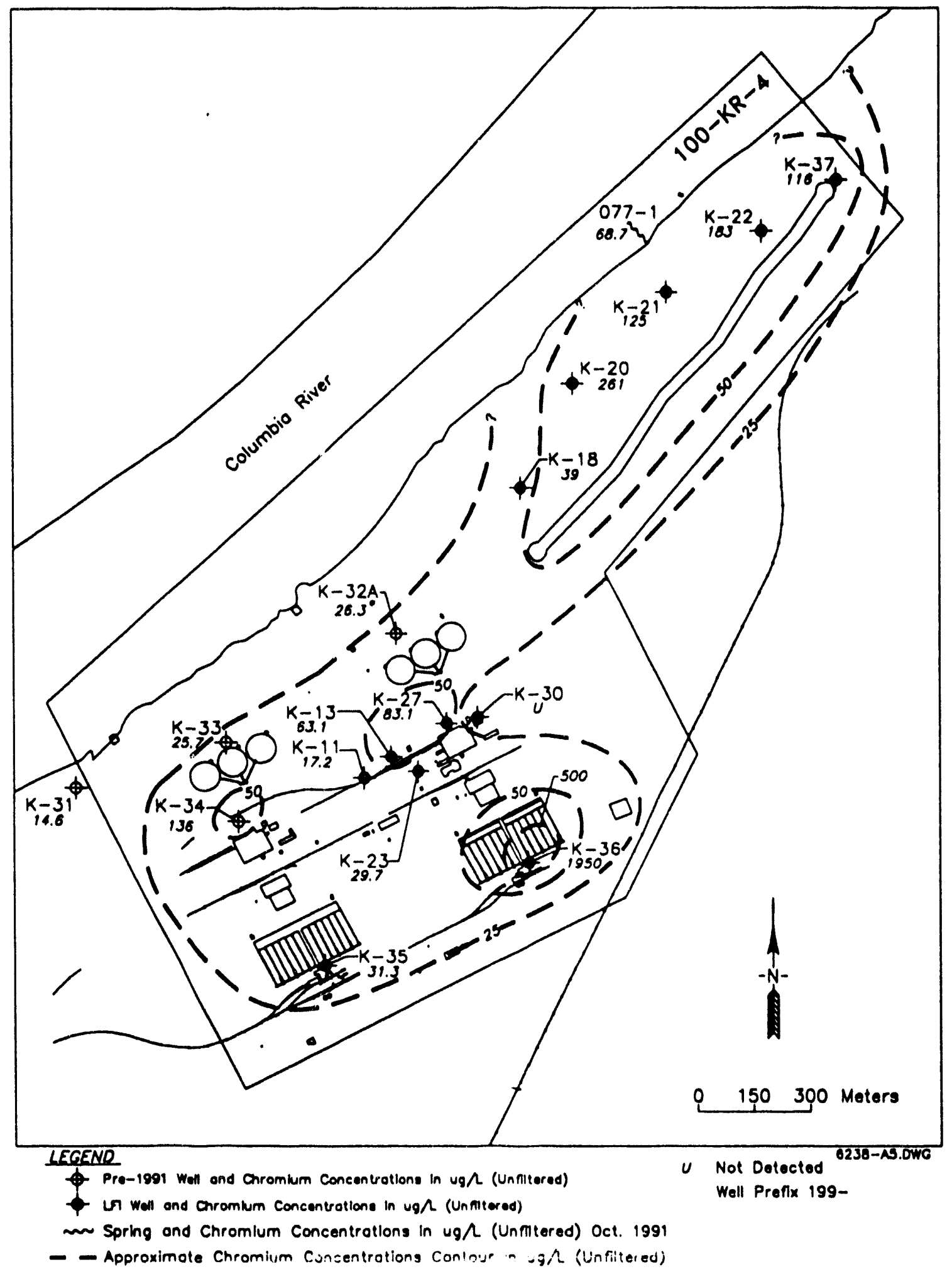

$4 \mathrm{~F}-1$ 
DOE/RL-93-79, Rev. 0

Figure 4-2 Arsenic Concentrations in the $100 \mathrm{~K}$ Area Groundwater

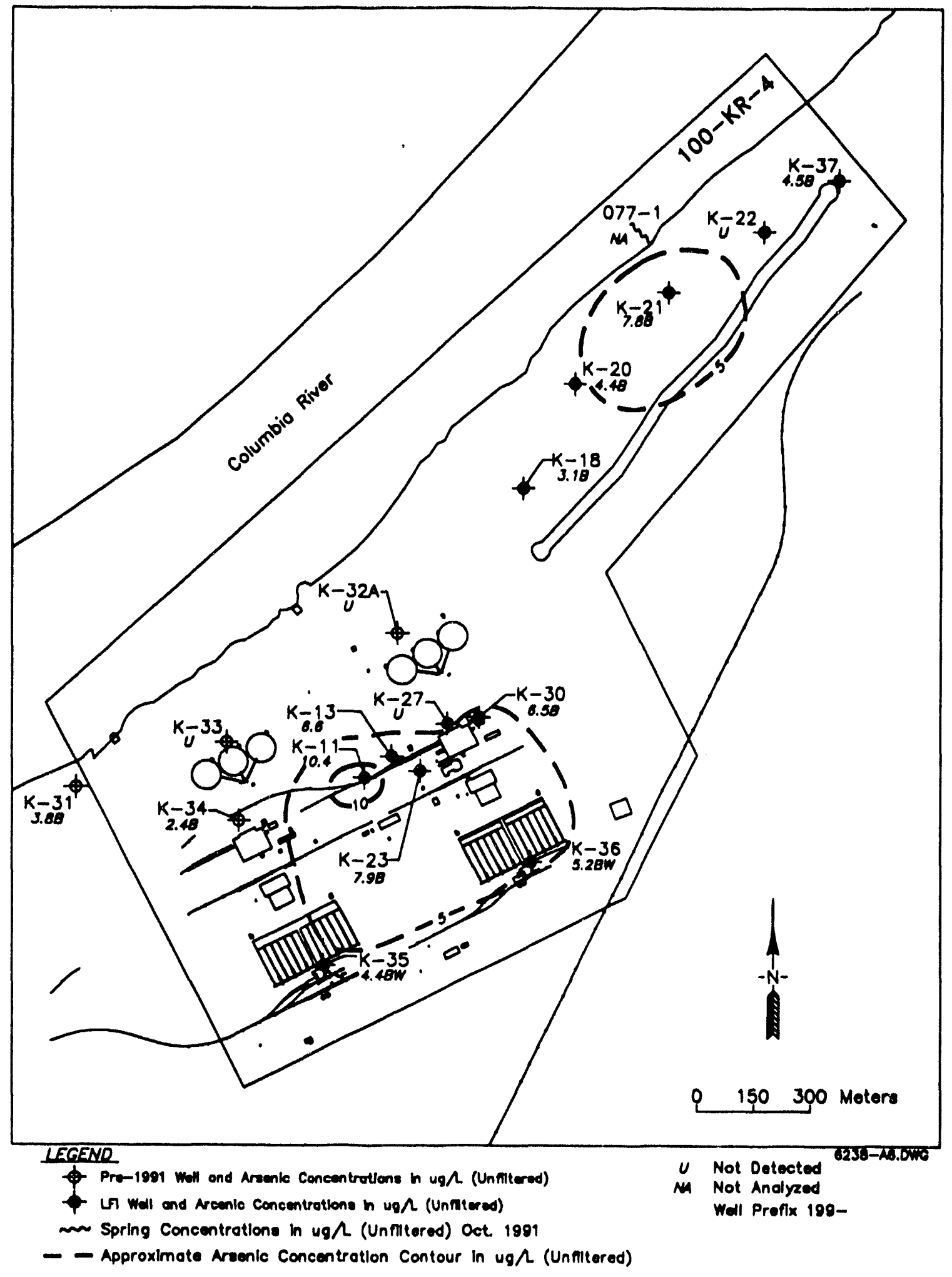

$4 \mathrm{~F}-2$ 
DOE/RL-93-79, Rev. 0

Figure 4-3 Tritium Concentrations in the $100 \mathrm{~K}$ Area Groundwater

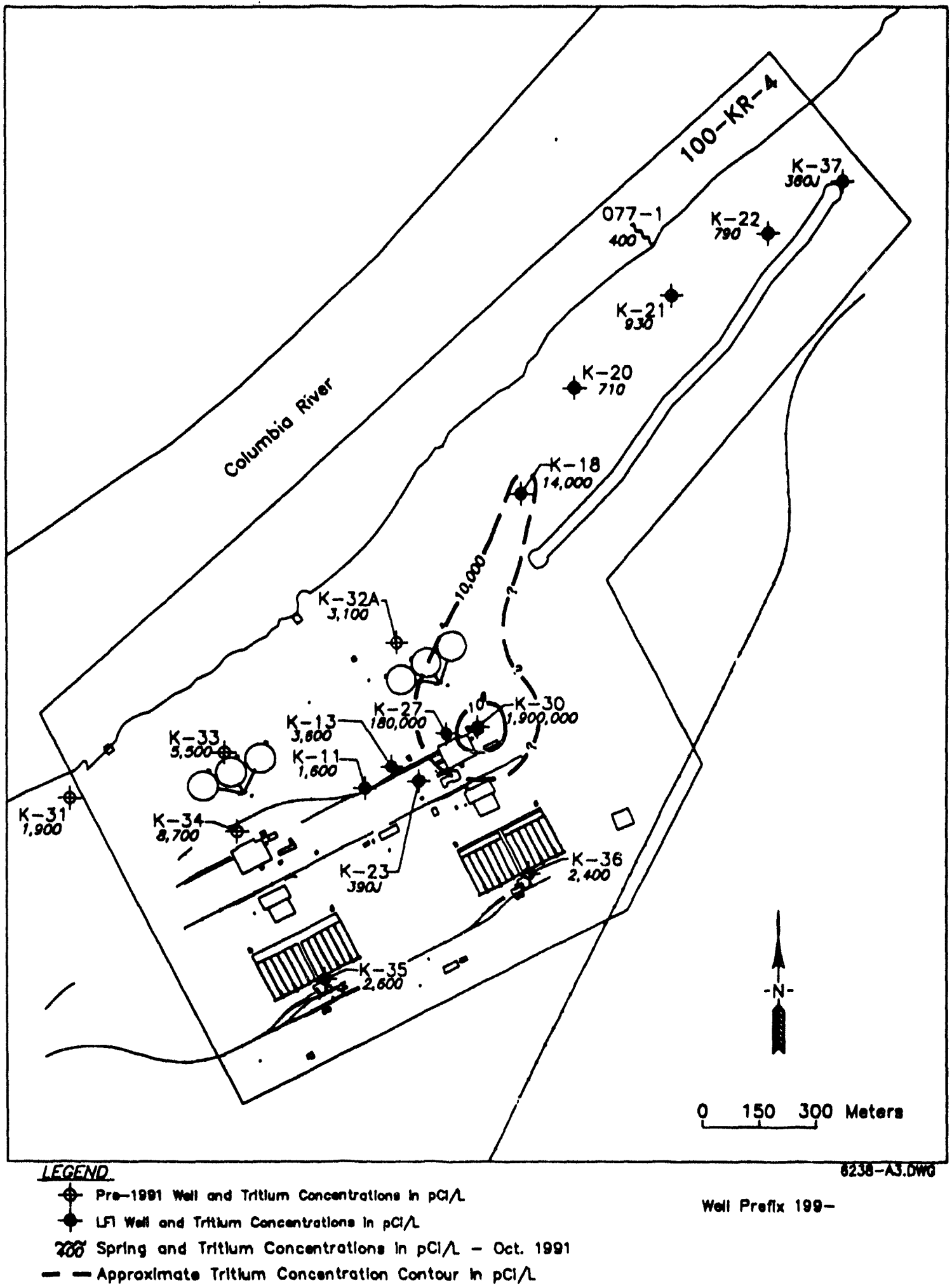

$4 \mathrm{~F}-3$ 
DOE/RL-93-79, Rev. 0

Figure 4-4 Carbon-14 Concentrations in the $100 \mathrm{~K}$ Area Groundwater

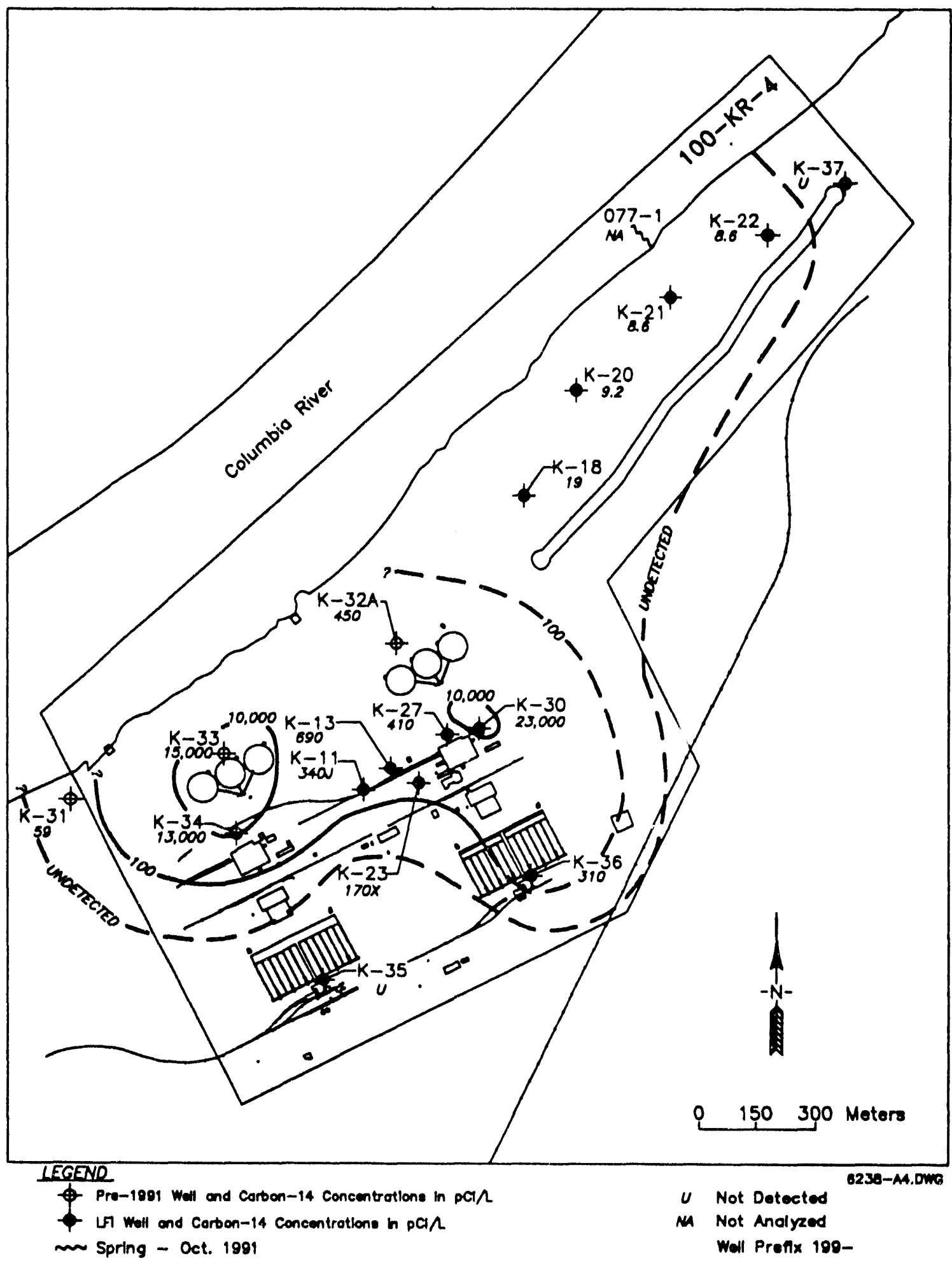

- Approximate Corbon-14 Concentrotion contour in PCI/ 
DOE/RL-93-79, Rev. 0

Table 4-1 100-KR-4 Risk Based Contaminants of Potential Concern Data (page 1 of 7 )

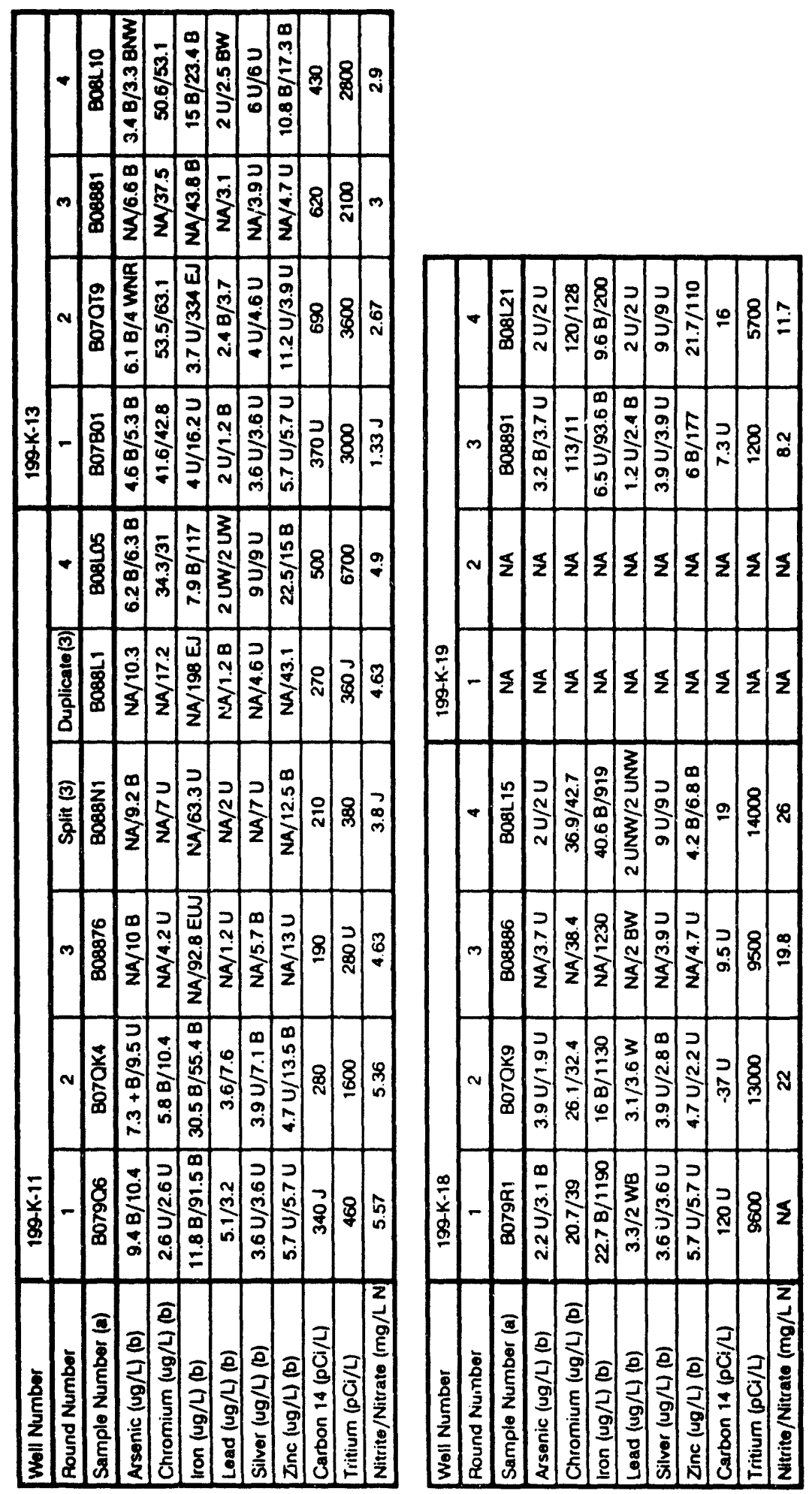

$4 \mathrm{~T}-1 \mathrm{a}$ 
DOE/RL-93-79, Rev. 0

Table 4-1 100-KR-4 Risk Based Contaminants of Potential Concern Data (page 2 of 7 )

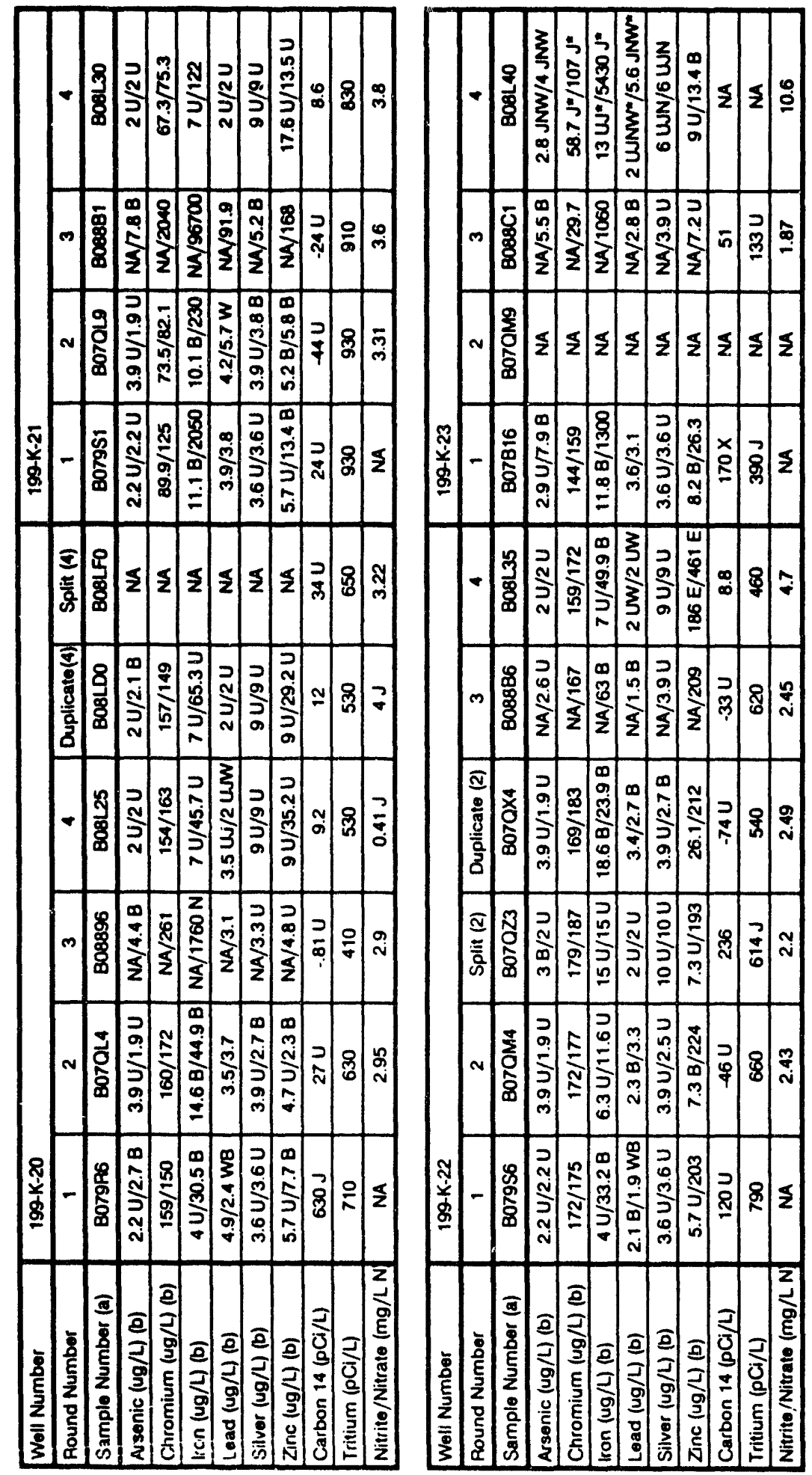


DOE/RL-93-79, Rev. 0

Table 4-1 100-KR-4 Risk Based Contaminants of Potential Concern Data (page 3 of 7 )

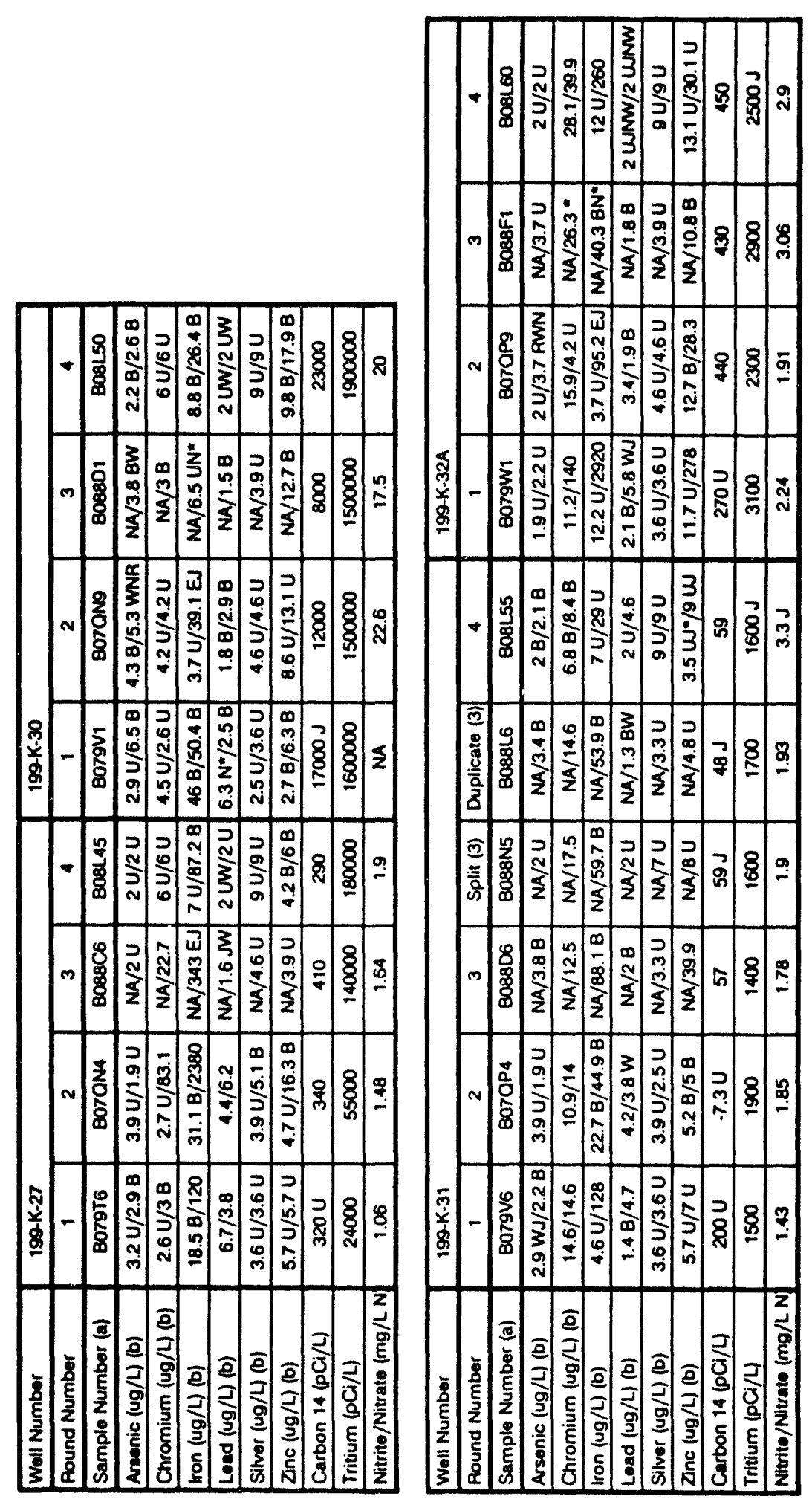

$4 T-1 \mathrm{C}$ 
DOE/RL-93-79, Rev. 0

Table 4-1 100-KR-4 Risk Based Contaminants of Potential Concern Data (page 4 of 7 )

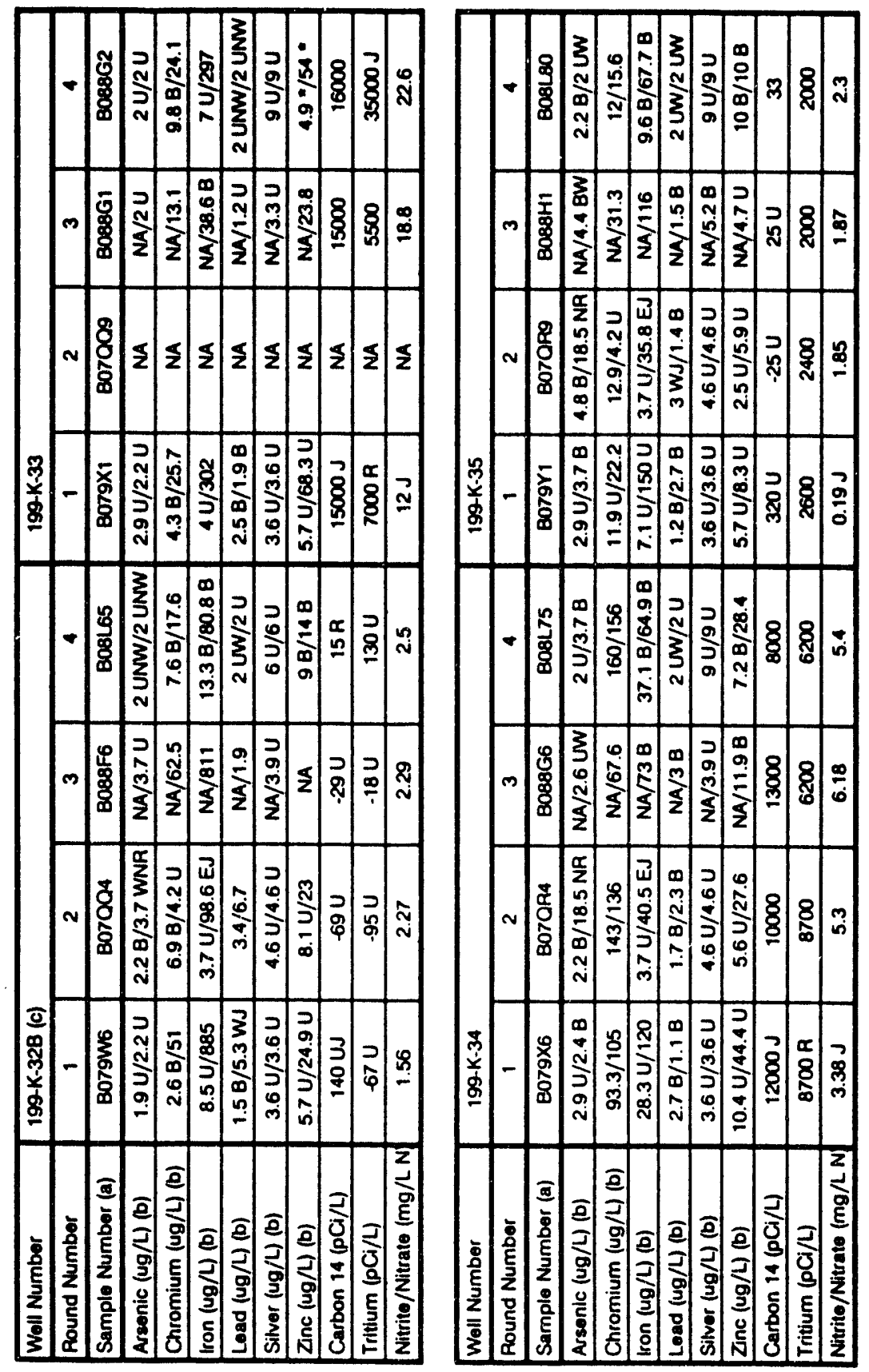


DOE/RL-93-79, Rev. 0

Table 41 100-KR-4 Risk Based Contaminants of Potential Concern Data (page 5 of 7 )

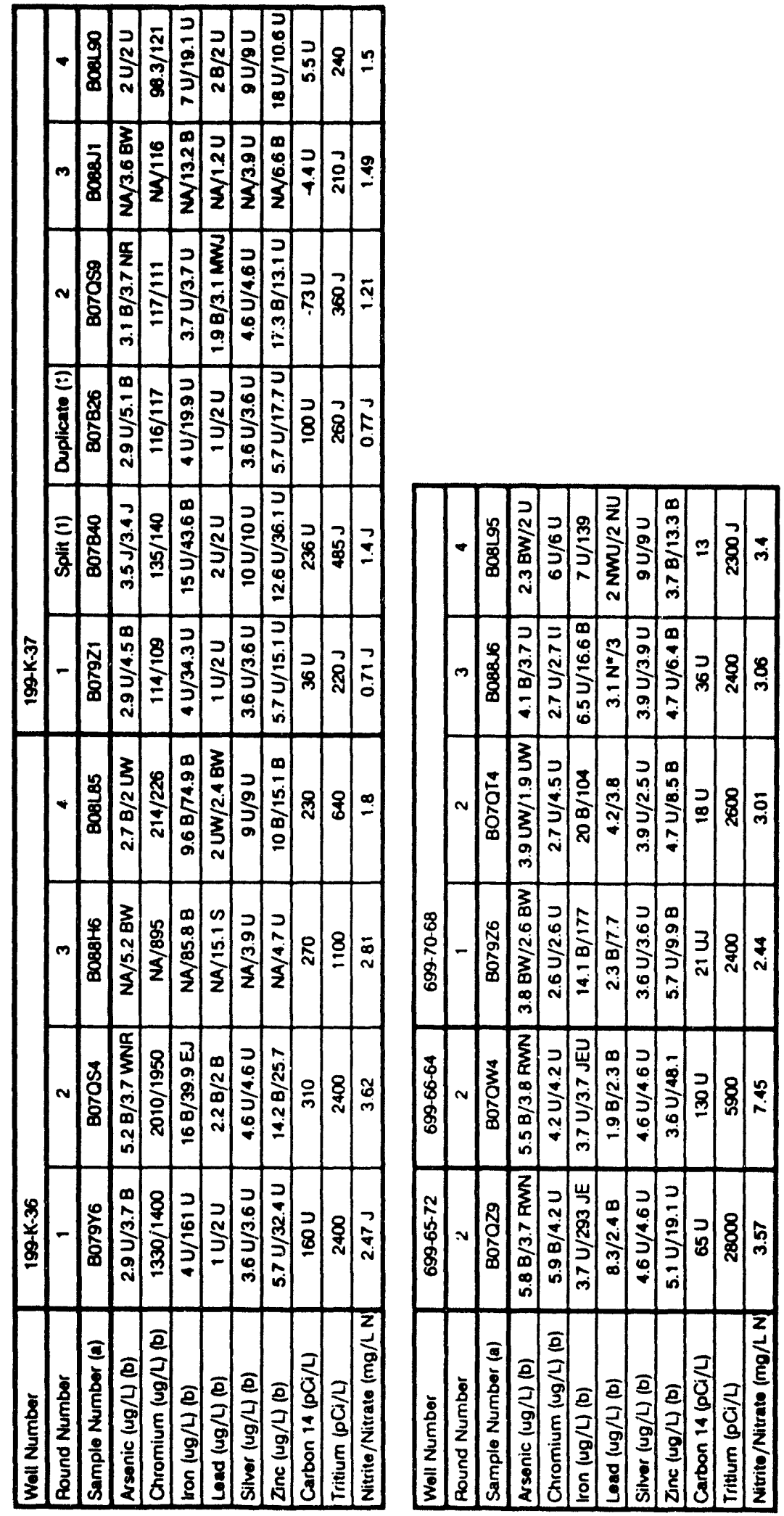

$4 \mathrm{~T}-1 \mathrm{e}$ 
DOE/RL-93-79, Rev. 0

Table 4-1 100-KR-4 Risk Based Contaminants of Potential Concern Data (page 6 of 7 )

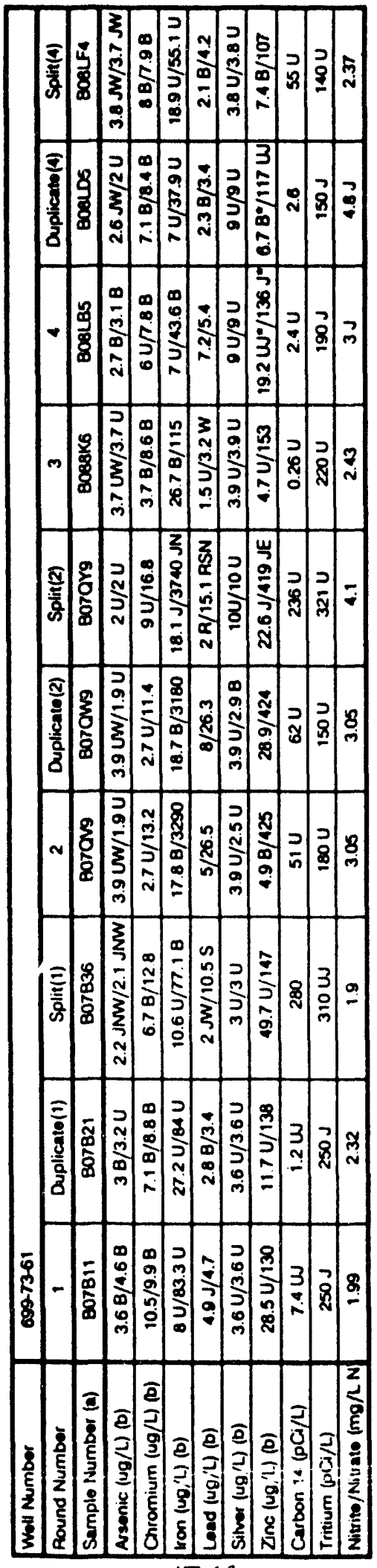

$4 \mathrm{~T}-1 \mathrm{f}$ 


\begin{tabular}{|c|c|c|c|c|}
\hline Woll Number & $699-78.62$ & & & \\
\hline Found Number & 1 & 2 & 3 & 4 \\
\hline Sample Number (a) & B07B06 & Bo7OV4 & Bo88K1 & BOBLBO \\
\hline Arsonic (ug/L) (b) & $5.38 / 4.8 \mathrm{BW}$ & $3.9 \mathrm{UW} / 1.9 \mathrm{UW}$ & $3.7 \mathrm{UW} / 5.1 \mathrm{BW}$ & $2.78 / 2 U$ \\
\hline Chromium (ug/L) (b) & $44.9 / 47.3$ & $40.6 / 48.9$ & $42.1 / 46.6$ & $36 / 42.5$ \\
\hline $\operatorname{Lron}(\mathrm{ug} / \mathrm{L})(\mathrm{D})$ & $16.3 \mathrm{~B} / 19.2 \mathrm{~B}$ & $8.68 / 11.6 \mathrm{U}$ & $6.5 \mathrm{U} / 65 \mathrm{~B}$ & $70 / 8.4 U$ \\
\hline Load (ug/L) (b) & $6.6 / 8.1$ & $3.2 \mathrm{MW} / 7.5 \mathrm{~W}$ & $2.78 / 3.1$ & $2 u w / 2 u$ \\
\hline Silver (ug/L) (b) & $3.6 \mathrm{U} / 3.6 \mathrm{U}$ & $3.9 \mathrm{U} / 3.3 \mathrm{~B}$ & $3.9 \mathrm{U} / 3.9 \mathrm{U}$ & $9 U / 9 U$ \\
\hline Zne (ug/L) (b) & $78 / 62.4$ & 4.7 U/67.4 & $22.7 / 60.9$ & $7.8 \mathrm{U} / 99.2$ \\
\hline Carbon $14(\mathrm{pCi} / \mathrm{L})$ & $52 \mathrm{~J}$ & $47 \mathrm{U}$ & $13 U$ & 110 \\
\hline Tritium $(\mathrm{pC} / \mathrm{L} / \mathrm{L})$ & 810 & $1.5 \mathrm{U}$ & $110 \mathrm{U}$ & 27 \\
\hline Autrrite/Nitrate (mg/L & 1.67 & 2 & 2.06 & 2.6 \\
\hline
\end{tabular}

Note: Undetects listed as " $U$ " without preceeding numbers, had no corresponding value reported

(a): Sample number reported for the majority of the analysis, inorganic filtored samplos have difforent sample numbers

(b): Filtered/Unfiltered

(c): Well completed in the confined aquifer

-: Duplicate analysis not within control limits

NA: Not Availablo

$U$ : Undetected, value is detection limit

N: Spiked sample recovery not within control limits

E: Estimated value due to the presence of interference

B: (inorganics) Estimated value bolow contract required detection limit

J: Estimated value

R: Pojectod data

W: M analysis outside of control limits

$X$. Some data necessary to compute the result, error or MDA was manually entered or modified

t: Corrolation coeflicient for the MSA is loss than 0.995 
DOE/RL-93-79, Rev. 0

Table 4-2 Determination of Constituents Exceeding Potential ARAR

\begin{tabular}{|c|c|c|c|c|c|}
\hline Constfuent & $\begin{array}{c}\text { Maximum } \\
\text { Defensible } \\
\text { Concentration }\end{array}$ & $\begin{array}{l}\text { Minimum } \\
\text { Potentlal } \\
\text { ARAR (a) }\end{array}$ & $\begin{array}{l}\text { Potential } \\
\text { ARAR- } \\
\text { based } \\
\text { COPC? }\end{array}$ & $\begin{array}{c}\text { Risk- } \\
\text { Based } \\
\text { Human- } \\
\text { Health } \\
\text { COPC? (b) }\end{array}$ & $\begin{array}{l}\text { Risk-8ased } \\
\text { Ecological } \\
\text { COPC? }\end{array}$ \\
\hline \multicolumn{6}{|c|}{ Radionucildes (pCi/L) } \\
\hline carbon-14 & 23000 & 2800 & $Y$ & $N$ & $\bar{Y}$ \\
\hline strontium-90 & 36 & 8.00 & $Y$ & $N$ & $\mathbf{N}$ \\
\hline technetlum-99 & 46 & $* \star$ & $\star \star$ & $N$ & $\mathbf{N}$ \\
\hline tritium & 1900000 & 20000 & $Y$ & $N$ & $\mathbf{N}$ \\
\hline uranium-233/234 & 2.6 & 24 & $\mathbf{N}$ & $N$ & $\mathbf{N}$ \\
\hline uranium-235 & 0.3 & 24 & $\mathbf{N}$ & $N$ & $\mathbf{N}$ \\
\hline uranium-238 & 3.3 & $* *$ & $\star \star$ & na & $\mathbf{N}$ \\
\hline \multicolumn{6}{|c|}{ Organic Compounds (ug/i) } \\
\hline chloroform & 17.0 & 5.40 & $\bar{Y}$ & $\because \ddot{N}$ & $N$ \\
\hline trichloroethene & 19.0 & 2.70 & $Y$ & $N$ & $\mathbf{N}$ \\
\hline \multicolumn{6}{|l|}{ Anions (mg/i) } \\
\hline chioride & 21.6 & 250 & $N$ & na & na \\
\hline nitrite/nitrate-N & 26 & 10 & $Y$ & $N$ & na \\
\hline sulfate & 109 & 250 & $N$ & na & na \\
\hline \multicolumn{6}{|l|}{ Cations (ug/L) } \\
\hline arsenic & 10.4 & 0.05 & Y & N" & na \\
\hline cadmium & 2.2 & 5.00 & $\mathbf{N}$ & $N$ & $\mathbf{N}$ \\
\hline cadmiurn* & 2.2 & 1.10 & $Y$ & & $Y$ \\
\hline chromium & 1950 & 50 & $Y$ & $N$ & \\
\hline chromium * & 261 & 11 & $Y$ & & $Y$ \\
\hline cobalt & 3.9 & $m$ & $\star *$ & na & na \\
\hline Iron & $5430 \mathrm{~J}$ & 3000 & $N$ & na & \\
\hline iron* & 1230 & & & & $Y$ \\
\hline lead & 7.6 & 22.40 & $N$ & na & \\
\hline lead* & $5.8 \mathrm{WJ}$ & 3.20 & $Y$ & & $Y$ \\
\hline manganese & 69.6 & 50.00 & $Y$ & $N$ & $N$ \\
\hline nickel & 18.7 & 100.00 & $N$ & $* \star$ & $N$ \\
\hline silver & 7.1 & ** & $* *$ & ** & $Y$ \\
\hline vanadium & 23.8 & $\star *$ & $\star \star$ & na & $\mathbf{N}$ \\
\hline zinc & $461 E$ & $\star \star \star$ & $\star \star$ & $N$ & $Y$ \\
\hline
\end{tabular}

"near-river well, exceeds chronic or acute protection freshwater aquatic species "no reported chemical specific ARAR
(a) as reported in DOE/RL.92-11
(b) Based on Occasional-Use Scenario
na: not available/not applicable 


\begin{tabular}{|c|c|c|c|c|c|c|c|c|}
\hline \multirow[t]{2}{*}{ Constituent } & \multicolumn{4}{|c|}{ Safe Drinking Water Act } & \multirow{2}{*}{$\begin{array}{c}\text { RCRA } \\
\text { Subpart F (c) }\end{array}$} & \multirow{2}{*}{$\begin{array}{c}\text { MTCA } \\
\text { (groundwater/ } \\
\text { surface water) } \\
\text { (I) }\end{array}$} & \multirow{2}{*}{$\begin{array}{l}\text { EPA Water } \\
\text { Qualing } \\
\text { Criteria } \\
\text { (chronicl } \\
\text { acute) (g) } \\
\end{array}$} & \multirow{2}{*}{$\begin{array}{l}\text { Washingtoon } \\
\text { Waler Quality } \\
\text { Standards } \\
\text { (ebronie/neve) } \\
\text { (b) }\end{array}$} \\
\hline & $\begin{array}{l}\text { Primary } \\
\text { MCL (a) }\end{array}$ & $\underset{\text { (b) }}{\text { MCLG }}$ & $\begin{array}{l}\text { Seconda:y } \\
\text { MCL (c) }\end{array}$ & $\begin{array}{l}\text { Proposed } \\
\text { MCL (d) }\end{array}$ & & & & \\
\hline Tritium & 20,000 & & & 60,900 & & & & \\
\hline Carbon-14 & 6.400 & & & 3,200 & & & & \\
\hline Chromium & 100 & 100 & & & 50 & $80 / 810$ & $11 / 16$ & $11 / 16$ \\
\hline Arsenic & 50 & 0 & & & 50 & 0.05 & & \\
\hline Chloroform & 100 & & & & & 7 & & \\
\hline Trichloroethene & 5 & & & & & 3 & $21,900 / 450,00$ & \\
\hline Nitrate/Nitrate-Nitrogen & 10,000 & & & & & 10,000 & & \\
\hline Cadmium & 5 & & & & & 8.5 & $1.1 / 3.9$ & \\
\hline Lead & 50 & & & & & 22.4 & $3.2 / 82$ & \\
\hline Manganese & 0 & & & & & 50 & & \\
\hline Strontium-90 & 8 & & & & & 8 & & \\
\hline \multicolumn{9}{|c|}{ 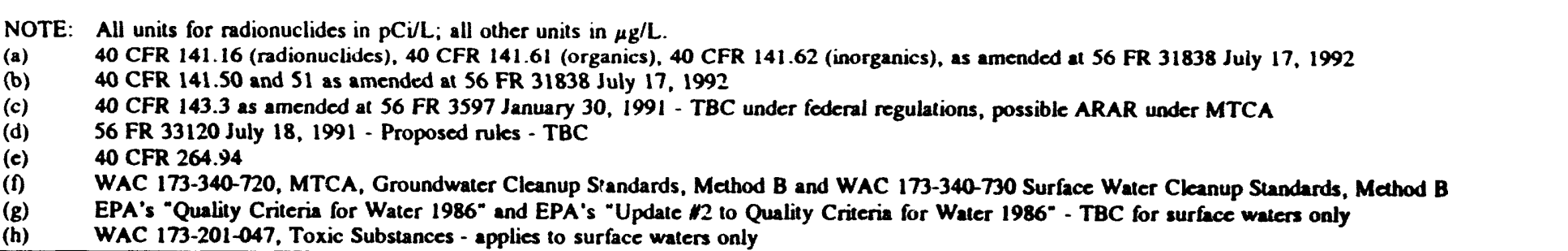 } \\
\hline
\end{tabular}




\section{S.0 CONCLUSIONS AND RECOMMENDATIONS}

The LFI for the 100-KR-4 Operable Unit was performed to provide additional data and characterization needed to support selection, design and implementation on IRMs, if needed. The analytical results from the groundwater sampling were compared to Hanford Site background values as well as calculated risk values and potential groundwater ARAR to determine COPC. Any decision to continue along or remove the operable unit from the IRM pathway is then based on analysis of these comparisons. If a medium or high risk is calculated for the occasional-use risk assessment scenario and/or a potential ARAR is violated and the concentration is greater than Hanford background, then the operable unit continue along the IRM pathway.

Based on the QRA and data presented in Chapter 4, arsenic, tritium, and carbon-14 have low carcinogenic risk under the occasional-use scenario and medium risk under the frequent-use scenario. Arsenic, chromium, and nitrate/nitrite have $\mathrm{HQ}<1$ under the occasional use scenario and $\mathrm{HQ}>1$ under the frequent-use scenario. Ecological risk (EHQ >1) results from concentrations of chromium, iron, lead, silver, zinc and carbon-14.

\subsection{CONCLUSIONS}

Contaminants appear to be entering the river, and have been for many years.

Radioactive decay is reducing the concentrations of tritium, but has relatively little impact on carbon- 14 or strontium-90 due to their relatively long half-lives.

Under the occasional-use scenario, calculated human-health risk is low to very low. Therefore no IRM is necessary based on risk. Numerous contaminants exceed potential ARAR levels; the site should remain on the IRM pathway. Groundwater remedial actions should be coordinated with the overlying source operable unit remediations to maximize their effectiveness.

The hydrologic properties of the aquifer system of the 100-KR-4 Operable Unit are such that contaminant migration is slow. This feature adds to the credibility of performing an IRM to remove specific groundwater contaminants in the $100 \mathrm{~K}$ Area as there is likely a slow release of contaminants to the Columbia River. Removal actions would be a reduction-of-mass operation that, pending results of a focused FS, could ultimately lead to early elimination of risk due to groundwater contaminants. It should be noted that the same characteristics that have served to contain the contaminant plumes will serve to restrict the contaminant retrieval capacity. 
DOE/RL-93-79, Rev. 0

\subsection{REFERENCES}

Becker, C.D., 1990, Aquatic Bloenvironmental Studies: The Hanford Experience 1944-84, Elsevier, New York.

Bouwer, H., 1989, The Bouwer and Rice Slug Test -- An Update, Groundwater, Vol. 27, No. 3, pp 304-309.

Bouwer, H. and R.C. Rice, 1976, A Slug Test for Determining Hydraulic Conductivity of Unconfined Aquifers with Completely or Partially Penetrating Wells, Water Resources Research, Vol. 12, No. 3, pp 423-428.

Campbell, M.D., W.J. McMahon, and K.R. Simpson, 1993, Water Level Measurements for Modeling Hydraulic Properties in the 300-FF-5 and 100 Aggregate Area Operable Units, PNL-8580, April 1993, Pacific Northwest Laboratory, Richland, Washington.

Dirkes, R.L., 1992, Columbia River Monitoring Data Compilation, WHC-SD-EN-DP-024, Rev. 0, Pacific Northwest Laboratory, Richland, Washington.

DOE-RL, 1991, Hanford Past-Practices Strategy, Draft A, DOE-RL 91-40, U.S. Department of Energy, Richland, Washington.

DOE-RL, 1992a, Remedial Investigation/Feasibility Study Work Plan for the 100-KR-4 Operable Unit, Hanford Site, Richland, Washington, DOE-RL 90-21, U.S. Department of Energy, Richland, Washington.

DOE-RL, 199; o, Hanford Site Groundwater Background, DOE/RL-92-23, U.S. Department of Ener;y, Richland, Washington.

DOE-RL, 1992c, Sampling and Analysis of 100 Area Springs, DOE/RL-92-12, Rev. 1, U.S. Department of Energy, Richland, Washington.

DOE-RL, 1992d, Environmental Assessment of 105-KE and 105-KW Basins Fuel Encapsulation and Repackaging, 100-K Area, Hanford Site, Richland, Washington, DOE/EA-0535, June 1992, U.S. Department of Energy, Richland, Washington.

DOE-RL, 1993a, 100 Area Feasibility Stucly Phases 1 and 2, DOE/RL-92-11, Draft B, U.S. Department of Energy, Richland, Washington.

DOE-RL, 1993b, Hanford Site Background: Part 1, Soil Background for Nonradioactive Analytes, DOE/RL-92-24, Revision 1, Draft, U.S. Department of Energy, Richland, Washington.

DOE-RL, 1993c, Hanford Site Baseline Risk Assessment Methodology, DOE/RL-91-45, Rev. 2, U.S. Department of Energy, Richland, Washington. 
EPA, 1986, Quality Criteria for Water 1986, U.S. Environmental Protection Agency, Office of Water Regulation and Standards. EPA/44015/86-001, Washington D.C.

EPA, 1988, Guidance for Conducting Remedial Investigations and Feasibility Studies Under CERCLA, Interim File, OSWER Directive 9355.3-01, Washington D.C.

EPA, 1989, Risk Assessment Guidance for Superfund, Vol. I Human Health Evaluation Manual (Part A), Interim Final, EPA-540 1-89 002, Washington D.C.

Hartman, M.J. and R.E. Peterson, 1992, Hydrologic Summary for the Northern Hanford Site, WHC-SD-EN-TI-023, Rev, 0, October 1992, Westinghouse Hanford Company, Richland, Washington.

Ledgerwood, R.K., 1991, Summaries of Well Construction Data and Field Observations for Existing 100 Aggregate Area Operable Unit Resource Protection Wells. WHC-SD-ERTI-006, Rev. 0, Westinghouse Hanford Company, Richland, Washington.

Lewis, R.E., and A.W. Pearson, 1992, A Catalog of Borehole Geophysics for the 100 Areas and Adjacent 600 Area, Hanford Site, 1962 to May 1992, PNL-8320, Pacific Northwest Laboratory, Richland, Washington.

Lindberg, J.W., 1993, Geology of the $100 \mathrm{~K}$ Area, Hanford Site, South-Central Washington, WHC-SD-EN-TI-155, Rev 0, Westinghouse Hanford Company, Richland, Washington.

Lindsey, K.A., 1991, Revised Stratigraphy for the Ringold Formation, Hanford Site, South Central Washington, WHC-SD-El H-EE-004, Westinghouse Hanford Company, Richland, Washington.

Lindsey, K.A., 1992, Geology of the Northern Part of the Hanford Site: An Outline of Data Sources and the Geologic Setting of the 100 Areas, WHC-SD-EN-TI-011, Westinghouse Hanford Company, Richland, Washington

NBS, 1963, Maximum Permissible Body Burdens and Maximum Permissible Concentrations of Radionuclides in Air or Water for Occupational Exposures, Handbook 69, Department of Commerce, National Bureau of Standards, Washington D.C.

Peterson, R.E., 1992, Hydrologic and Geologic Data Available for the Region North of Gable Mountain, Hanford Site, Washington, WHC-SD-EN-TI-006, Rev. 0, March 1992, Westinghouse Hanford Company, Richland, Washington.

Peterson, R.E., and V.G. Johnson, 1992, Riverbank Seepage of Groundwater Along the Hanford Reach of the Columbia River Shoreline, Hanford Site, Washington, WHC-SA-1674-VA, Westinghouse Hanford Company, Richland, Washington. 
Weiss, S.G., and R.M. Mitchell, 1992, A Symihesis of Ecological Data from the 100 Areas of the Hanford Site, WHC-EP-0601, Westinghouse Hanford Company, Richland, Washington.

WHC, 1988, Environmental Investigations and Site Characterization Manual, WHC-CM7-7, Westinghouse Hanford Company, Richland, Washington.

WHC, 1990, Sample Management Administration Manual, WHC-CM-5-3, Westinghouse Hanford Company, Richland, Washington.

WHC, 1993a, Data Validation Report for the 100-KR-4 Operable Unit Groundwater Samples, WHC-SD-EN-TI-135, Westinghouse Hanford Company, Richland, Washington.

WHC, 1993b, Data Validation Report for the 100-KR-4 Operable Unit Second Round Groundwater Sampling, WHC-SD-EN-TI-182, Westinghouse Hanford Company, Richland, Washington.

WHC, 1993c, Data Validation Report for the 100-KR-4 Operable Unit Third Round Groundwater Sampling, WHC-SD-EN-TI-184, Westinghouse Hanford Company, Richland, Washington.

WHC, 1993d, Data Validation Report for the 100-KR-4 Operable Unit Fourth Round Groundwater Sampling, WHC-SD-EN-TI-200, Westinghouse Hanford Company, Richland, Washington.

WHC, 1993e, 100-KR-4 Groundwater Operable Unit Qualitative Risk Assessment, WHC-SDEN-RA-010, Rev. 0, Westinghouse Hanford Company, Richland, Washington. 
DOE/RL-93-79, Rev. 0

APPENDIX A

MAXIMUM CONCENTRATION SCREENING LOGIC

A-1 
This appendix presents those data that were rejected during the screening process described in Section 2.4.1. Data were screened for internal and external consistency. Internal consistency refers to a constituent occurring in multiple samplings of a given well at levels found to be reasonably constant or increasing. External consistency refers to a constituent that might reasonably be expected to occur at a well location based on its presence in nearby wells or due to the proximity of the well to a waste site that could contribute that constituent to the groundwater.

These screening tests were implemented to account for the chemical alterations that take place in aquifer materials when they are disrupted during the well construction process and variability in laboratory results. Under most conditions groundwater chemistry does not change markedly over a span of several months. When groundwater become contaminated the resultant contamination will appear in subsequent samplings. The screening process has served to draw focus on constituents that represent true alterations of groundwater chemistry resulting from past operable unit activities.

Screening was accomplished from the highest concentration down (i.e., the appendix only presents those data which represent sample concentrations above those used for the LFI and QRA analyses). For radiological contaminants the concentration was considered a nondetect if the two sigma error bound equalled or exceeded the reported value. Due to the statistical nature of radiological analyses some values reported by the laboratory are negative; these values were considered nondetections. For all constituents, if the laboratory reported a nondetection (qualifier $=\mathrm{U}$ ) those were considered as not present. Results from split (Quality Control) samples were not used in determining the maximum diffusible concentrations. The potential for inconsistencies in laboratory procedures was deemed sufficiently great to preclude the use of sample split analyses in the decision-making process.

Terms used to describe the reasons for rejection of specific analyses include:

\section{Not consistent between rounds:}

This means one of two things; either the reported concentrations differ greatly between rounds or that the constituent is present in only one of the four rounds of LFI sampling.

\section{Not equilibrated/Well not stabilized:}

As a result of physical and chemical changes due to well installation the constituent concentration is much higher in the first sample period and then rapidly reduces to a relatively consistent values. Those concentrations interpreted as being nonrepresentative due to well construction were eliminated. The highest concentration following equilibration was used in the LFI and in the QRA. 
Externally inconsistent:

An analyte is reported for a single well in one or two rounds and all surrounding and downgradient wells show no detects. If there is no known or suspected source for the analyte, the reported value is found externally inconsistent.

\section{Error bound exceeds value:}

This descriptor refers solely to radionuclide analyses. Radiochemical analyses are statistically generated based on the sample count and a parallel background count. At low concentrations it is common that the statistical error bound exceeds the determined sample concentration. These analyses have been rejected as nondetections.

\section{$\underline{\text { Result from split analysis: }}$}

To maintain consistency of method and results, split sample analyses (those sent to a separate laboratory) were not used in this assessment.

Bad analysis:

Well K-21, Round 3. 
DOE/RL-93-79, Rev. 0

Table A-1 100-KR-4 Rejected Maximum Concentrations and Logic (page 1 of 4)

Volatiles (ug/L)

\begin{tabular}{|c|c|c|c|c|}
\hline Analyte & Value & Well & Round & Logic behind rejection \\
\hline \multirow[t]{2}{*}{ 1,1,1-Trichloroethane } & $1 \mathrm{~J}$ & $\mathrm{~K}-30$ & 1 & Single detection \\
\hline & $1 \mathrm{~J}$ & K-35 & 2 & Single detectlon \\
\hline 2-Butanone & $5 \mathrm{~J}$ & $\mathrm{~K}-22$ & 3 & Single detection \\
\hline \multirow[t]{5}{*}{ Acetone } & 11 & $\mathrm{~K}-37$ & 1 & Result from split sample analysis \\
\hline & 11 & K-35 & 1 & Single detection \\
\hline & 11 & K-21 & 3 & Single detection \\
\hline & 6BJ & K-22 & 2 & Result from split sample analysis \\
\hline & $3 \mathrm{~J}$ & K-31 & 3 & Blank detection of 23 \\
\hline \multirow[t]{4}{*}{ Benzene } & $1 \mathrm{~J}$ & $\mathrm{~K}-21$ & 1 & Single detection \\
\hline & $1 \mathrm{~J}$ & K-22 & 1 & Single detection \\
\hline & $1 \mathrm{~J}$ & K-30 & 1 & Single detection \\
\hline & $1 \mathrm{~J}$ & K-31 & 1. & Single detection \\
\hline Carbon disulfide & $2 J$ & K-35 & 3 & Single detection \\
\hline \multirow[t]{7}{*}{ Methylenechloride } & $13 \mathrm{~B}$ & K-37 & 1 & Result from split sample analysis \\
\hline & 5BJ & K-18 & 1 & Single detection \\
\hline & $5 \mathrm{BJ}$ & $\mathrm{K}-20$ & 1 & Single detection \\
\hline & $5 \mathrm{BJ}$ & $\mathrm{K}-22$ & 1 & Single detection \\
\hline & $4 \mathrm{~J}$ & $\mathrm{~K}-23$ & 1 & Blank detection of $8 \mathrm{~J}$ \\
\hline & $4 \mathrm{~J}$ & K-37 & 1 & Blank detection of $3 \mathrm{~J}$ \\
\hline & $3 \mathrm{~J}$ & $\mathrm{~K}-30$ & 1 & Single detection \\
\hline \multirow[t]{3}{*}{ Toluene } & $3 \mathrm{~J}$ & $\mathrm{~K}-30$ & 3 & Single detection \\
\hline & $2 J$ & $\mathrm{~K}-27$ & 3 & Single detection \\
\hline & $2 J$ & $\mathrm{~K}-35$ & 2 & Single detection \\
\hline
\end{tabular}

Radioisotopes (pCi/L)

\begin{tabular}{|l|c|l|c|l|}
\hline Analyte & Value & Well & Round & Logic behind rejection \\
\hline Americium-241 & $0.468 \mathrm{~A}$ & $\mathrm{~K}-22$ & 2 & Result from split sample analysis \\
\hline & 0.14 & $\mathrm{~K}-36$ & 4 & Single detection \\
\hline & $0.032 \mathrm{R}$ & $\mathrm{K}-21$ & 2 & Single detection \\
\hline & $0.031 \mathrm{R}$ & $\mathrm{K}-33$ & 1 & Single detection \\
\hline Cobalt-60 & $0: 002 \mathrm{R}$ & $\mathrm{K}-30$ & 1 & Single detection \\
\hline Gross Beta & 17 & $\mathrm{~K}-23$ & 1 & Single detection \\
\hline Potassium-40 & 200 & $\mathrm{~K}-21$ & 3 & Not consistent between rounds \\
\hline & 210 & $\mathrm{~K}-13$ & 3 & Not consistent between rounds \\
\hline & 140 & $\mathrm{~K}-36$ & 3 & Single detection \\
\hline Radium-226 & 87.2 & $\mathrm{~K}-13$ & 4 & Not consistent between rounds \\
\hline & 22 & $\mathrm{~K}-20$ & 4 & Result from split sample analysis \\
\hline Strontium-90 & 17 & $\mathrm{~K}-13$ & 3 & Single detection \\
\hline Thorium-228 & 100 & $\mathrm{~K}-21$ & 3 & Not consistent between rounds \\
\hline & 10 & $\mathrm{~K}-37$ & 4 & Single detection \\
\hline & 9.4 & $\mathrm{~K}-35$ & 4 & Single detection \\
\hline Zinc-65 & 8.4 & $\mathrm{~K}-27$ & 4 & Single detection \\
\hline
\end{tabular}


DOE/RL-93-79, Rev. 0

Table A-1 100-KR-4 Rejected Maximum Concentrations and Logic (page 2 of 4)

Wet Chemistry and Anions ( $\mathrm{mg} / \mathrm{L}$ )

\begin{tabular}{|c|c|c|c|c|}
\hline Analyte & Value & Well & Round & Logic behind rejection \\
\hline \multirow[t]{9}{*}{ Ammonia } & $0.3 \mathrm{~J}$ & $\mathrm{~K}-33$ & 1 & Single detection \\
\hline & 0.22 & $\mathrm{~K}-18$ & 1 & Single detectlon \\
\hline & 0.1 & $\mathrm{~K}-36$ & 1 & Single detection \\
\hline & $0.09 \mathrm{~J}$ & $\mathrm{~K}-37$ & 2 & Single detection \\
\hline & $0.08 \mathrm{~J}$ & K-32A & 1 & Single detection \\
\hline & $0.07 \mathrm{~J}$ & $\mathrm{~K}-34$ & 1 & Single detection \\
\hline & 0.05 & $\mathrm{~K}-13$ & 1 & Single detection \\
\hline & 0.05 & $\mathrm{~K}-30$ & 1 & Single detection \\
\hline & 0.05 & $\mathrm{~K}-21$ & 1 & Single detection \\
\hline \multirow[t]{2}{*}{ Chloride } & 225 & $\mathrm{~K}-18$ & 4 & Not consistent between rounds \\
\hline & 25.8 & $\mathrm{~K}-22$ & 2 & Result from split sample analysis \\
\hline Fluoride & 4 & $K-11$ & 1 & Not consistent between rounds \\
\hline \multirow[t]{4}{*}{ Phosphate } & 0.4 & $\mathrm{~K}-13$ & 1 & Not consistent between rounds \\
\hline & 0.4 & $\mathrm{~K}-30$ & 1 & Not consistent between rounds \\
\hline & $0.4 \mathrm{R}$ & $\mathrm{K}-20$ & 4 & Result from split sample analysis \\
\hline & $0.25 \mathrm{~J}$ & K-31 & 4 & Single detection \\
\hline Sulfate & 4100 & $\mathrm{~K}-22$ & 2 & Result from split sample analysis \\
\hline \multirow[t]{5}{*}{ Sulfides } & 1 & $\mathrm{~K}-13$ & 1 & Not consistent between rounds \\
\hline & 1R & $\mathrm{K}-20$ & 4 & Result from split sample analysis \\
\hline & $1 \mathrm{R}$ & $\mathrm{K}-13$ & 2 & Holding time exceeded \\
\hline & $1 R$ & $\mathrm{~K}-30$ & 2 & Holding time exceeded \\
\hline & 1R & $\mathrm{K}-32 \mathrm{~A}$ & 2 & Holding time exceeded \\
\hline
\end{tabular}

Semi-Volitales (ug/I)

\begin{tabular}{|l|c|l|c|l|}
\hline Analyte & Value & Well & Round & Logic behind rejection \\
\hline Dl-n-butylphthalate & $2 \mathrm{JB}$ & $\mathrm{K}-37$ & 1 & Result from split sample analysis \\
\hline & $0.6 \mathrm{BJ}$ & $\mathrm{K}-31$ & 3 & Result from split sample analysis \\
\hline Diethylphthalate & $2 \mathrm{~J}$ & $\mathrm{~K}-31$ & 3 & Single detection \\
\hline
\end{tabular}


DOE/RL-93-79, Rev. 0

Table A-1 100-KR-4 Rejected Maximum Concentrations and Logic (page 3 of 4)

Unfiltered Inorganics (ug/L)

\begin{tabular}{|c|c|c|c|c|}
\hline Analyte & Value & Well & Round & Logic behind rejection \\
\hline \multirow[t]{4}{*}{ Aluminum } & 48900 & $\mathrm{~K}-21$ & 3 & Bad analysis \\
\hline & 1590 & $\mathrm{~K}-32 \mathrm{~A}$ & 1 & Single detection \\
\hline & 1000 & $\mathrm{~K}-21$ & 1 & Not consistent between rounds \\
\hline & 960 & K-27 & 2 & Not consistent between rounds \\
\hline \multirow[t]{4}{*}{ Antimony } & $43.6 \mathrm{~B}$ & $K-21$ & 3 & Bad analysis \\
\hline & $28.1 \mathrm{~B}$ & K-36 & 2 & Single detection \\
\hline & $20.7 \mathrm{~B}$ & $K-18$ & 3 & Single detection \\
\hline & $19.1 \mathrm{~B}$ & $\mathrm{~K}-34$ & 3 & Single detection \\
\hline \multirow[t]{2}{*}{ Arsenic } & $18.5 \mathrm{NR}$ & K-34 & 2 & Not consistent between rounds \\
\hline & $18.5 \mathrm{NR}$ & K-35 & 1 & Not consistent between rounds \\
\hline Barium & 794 & $\mathrm{~K}-21$ & 3 & Bad analysis \\
\hline \multirow[t]{8}{*}{ Beryllium } & $3.2 \mathrm{~B}$ & K-22 & 2 & Single detection \\
\hline & $2.7 \mathrm{~B}$ & $K-18$ & 2 & Single detection \\
\hline & $2.6 \mathrm{~B}$ & K-21 & 3 & Bad analysis \\
\hline & $1.6 \mathrm{~B}$ & $\mathrm{~K}-20$ & 2 & Single detection \\
\hline & $1.1 \mathrm{~B}$ & K-27 & 2 & Single detection \\
\hline & $1.1 \mathrm{~B}$ & K-31 & 2 & Single detection \\
\hline & $1.1 \mathrm{~B}$ & K-21 & 2 & Single detection \\
\hline & $1.1 \mathrm{~B}$ & $\mathrm{~K}-11$ & 2 & Single detection \\
\hline Cadium & $5 \mathrm{RN}^{*}$ & $\mathrm{~K}-20$ & 4 & Not consistent between rounds \\
\hline Calcium & 327000 & $\mathrm{~K}-21$ & 3 & Bad analysis \\
\hline Chromiun & 2040 & K-21 & 3 & Bad analysis \\
\hline Cobalt & 74.2 & $\mathrm{~K}-21$ & 3 & Bad analysis \\
\hline \multirow[t]{15}{*}{ Copper } & 195 & $\mathrm{~K}-21$ & 3 & Bad analysis \\
\hline & $19.4 \mathrm{~B}$ & K-27 & 2 & Single detection \\
\hline & $13.7 \mathrm{~B}$ & $K-20$ & 3 & Single detection \\
\hline & $11.7 \mathrm{~B}$ & K-23 & 4 & Single detection \\
\hline & $9.9 \mathrm{~B}$ & $\mathrm{~K}-30$ & 3 & Result from split sample analysis \\
\hline & $9.3 \mathrm{~B}$ & $K-31$ & 3 & Single detection \\
\hline & $7 \mathrm{~B}$ & K-32A & 3 & Single detection \\
\hline & $6.6 \mathrm{~B}$ & $\mathrm{~K}-30$ & $: 2$ & Not consistent between rounds \\
\hline & $5.2 \mathrm{~B}$ & K-35 & 3 & Single detection \\
\hline & $5.6 \mathrm{~B}$ & $\mathrm{~K}-19$ & 3 & Single detection \\
\hline & $5.6 \mathrm{~B}$ & $\mathrm{~K}-13$ & 2 & Single detection \\
\hline & $5.1 \mathrm{~B}$ & $K-23$ & 1 & Single detection \\
\hline & $3.5 \mathrm{~B}$ & $\mathrm{~K}-18$ & 3 & Single detection \\
\hline & $3.2 \mathrm{~B}$ & $\mathrm{~K}-22$ & 3 & Single defection \\
\hline & $1.9 \mathrm{~B}$ & $K-21$ & 1 & Not consistent between rounds \\
\hline Iron & 96700 & K-21 & 3 & Bad analysis \\
\hline \multirow[t]{2}{*}{ Lead } & 91.9 & K-21 & 3 & Bad analysis \\
\hline & $15.1 \mathrm{~S}$ & $K-36$ & 3 & Not consistent between rounds \\
\hline Magnesium & 35900 & $\mathrm{~K}-21$ & 3 & Bad analysis \\
\hline \multirow[t]{5}{*}{ Manganese } & 5390 & $\mathrm{~K}-21$ & 3 & Bad analysis \\
\hline & 183 & K.34 & 1 & Not consistent between rounds \\
\hline & 117 & K-23 & 4 & Not consistent between rounds \\
\hline & 101 & $\mathrm{~K}-27$ & 2 & Not consistent between rounds \\
\hline & $87.2 \mathrm{EJ}$ & K-36 & 1 & Well not equilibrated \\
\hline
\end{tabular}

AT-IC 
DOE/RL-93-79, Rev. 0

Table A-1 100-KR-4 Rejected Maximum Concentrations and Logic (page 4 of 4)

Unfittered Inorganics (ug/L)

\begin{tabular}{|c|c|c|c|c|}
\hline Analyte & Value & Well & Round & Logic behind rejection \\
\hline \multirow[t]{5}{*}{ Mercury } & $0.19 \mathrm{~B}$ & $K-35$ & 1 & Single detectlon \\
\hline & $0.14 B$ & $\mathrm{~K}-18$ & 1 & Single detection \\
\hline & $0.14 \mathrm{~B}$ & K-22 & 1 & Single detection \\
\hline & $0.13 \mathrm{~B}$ & $\mathrm{~K}-36$ & 1 & Single detection \\
\hline & $0.11 \mathrm{~B}$ & $\mathrm{~K}-30$ & 1 & Single detection \\
\hline \multirow[t]{5}{*}{ Nickel } & 953 & $\mathrm{~K}-21$ & 3 & Bad analysis \\
\hline & 77.6 & $\mathrm{~K}-27$ & 2 & Not consistent between rounds \\
\hline & 69.4 & $\mathrm{~K}-32 \mathrm{~A}$ & 1 & Well not equilibrated \\
\hline & 57.9 & $\mathrm{~K}-20$ & 3 & Single detection \\
\hline & $28.7 \mathrm{~B}$ & K-21 & 1 & Not consistent between rounds \\
\hline \multirow[t]{14}{*}{ Selenium } & 16.5WNR & $\mathrm{K}-13$ & 2 & Single detection \\
\hline & $16.5 \mathrm{NR}$ & $\mathrm{K}-35$ & 2 & Single detection \\
\hline & 16.5 WNR & $\mathrm{K}-36$ & 2 & Single detection \\
\hline & $16.5 \mathrm{NR}$ & K-37 & 2 & Single detection \\
\hline & $16.5 \mathrm{RN}$ & $\mathrm{K}-13$ & 2 & Single detection \\
\hline & $6.4 \mathrm{NS}$ & $K-30$ & 4 & Not consistent between rounds \\
\hline & 4 BNS & $\mathrm{K}-20$ & 3 & Not consistent between rounds \\
\hline & $3.1 \mathrm{~B}$ & K-35 & 4 & Not consistent between rounds \\
\hline & $2.7 \mathrm{BW}$ & $\mathrm{K}-13$ & 4 & Single detection \\
\hline & $2.7 \mathrm{BW}$ & $\mathrm{K} \cdot 33$ & 4 & Single detection \\
\hline & $2.6 \mathrm{WJ}$ & $\mathrm{K}-22$ & 2 & Result from split sample analysis \\
\hline & $2.2 \mathrm{JW}$ & $\mathrm{K}-23$ & 4 & Single detection \\
\hline & $2.1 \mathrm{BW}$ & $\mathrm{K}-11$ & 4 & Single detection \\
\hline & 2RN* & K-20 & 4 & Not consistent between rounds \\
\hline Sodium & 31400 & $\mathrm{~K}-11$ & 3 & Result from split sample analysis \\
\hline \multirow[t]{3}{*}{ Vanadium } & 117 & $\mathrm{~K}-21$ & 3 & Bad analysis \\
\hline & $31.2 \mathrm{~B}$ & $\mathrm{~K}-11$ & 3 & Result from split sample analysis \\
\hline & $29.4 B$ & $\mathrm{~K}-33$ & 4 & Single detection \\
\hline
\end{tabular}


Table A-2 100-KR-4 Rejected Near-River Maximum Concentrations and Logic (page 1 of 3)

\begin{tabular}{|l|c|l|c|l|l|}
\hline Analyte & Value & Well & Round & Logic behind rejection \\
\hline 2-Butanone & $5 \mathrm{~J}$ & $\mathrm{~K}-22$ & 3 & Single detection \\
\hline Acetone & 11 & $\mathrm{~K}-37$ & 1 & Result from split sample analysis \\
\hline & 11 & $\mathrm{~K}-21$ & 3 & Single detection \\
\hline & $6 \mathrm{BJ}$ & $\mathrm{K}-22$ & 2 & Result from split sample analysis \\
\hline & $3 \mathrm{~J}$ & $\mathrm{~K}-31$ & 3 & Blank detection of 23 \\
\hline Benzene & $1 \mathrm{~J}$ & $\mathrm{~K}-21$ & 1 & Single detection \\
\hline & $1 \mathrm{~J}$ & $\mathrm{~K}-22$ & 1 & Single detection \\
\hline & $1 \mathrm{~J}$ & $\mathrm{~K}-31$ & 1 & Single detection \\
\hline Methylenechloride & $13 \mathrm{~B}$ & $\mathrm{~K}-37$ & 1 & Result from split sample analysis \\
\hline & $5 \mathrm{BJ}$ & $\mathrm{K}-18$ & 1 & Single detection \\
\hline & $5 \mathrm{BJ}$ & $\mathrm{K}-20$ & 1 & Single detection \\
\hline & $5 \mathrm{BJ}$ & $\mathrm{K}-22$ & 1 & Single detection \\
\hline & $4 \mathrm{~J}$ & $\mathrm{~K}-37$ & 1 & Blank detection of 3 J \\
\hline
\end{tabular}

Radioisotopes (pCi/L)

\begin{tabular}{|l|c|l|c|l|l|}
\hline Analyte & Value & Well & Round & Logic behind rejection \\
\hline Americit 7 n-241 & $0.468 \mathrm{R}$ & $\mathrm{K}-22$ & 2 & Result from split sample analysis \\
\hline & $0.032 \mathrm{R}$ & $\mathrm{K}-21$ & 2 & Single detection \\
\hline & $0.031 \mathrm{R}$ & $\mathrm{K}-33$ & 1 & Single detection \\
\hline & 6.8 & $\mathrm{~K}-34$ & 4 & Not consistent between rounds \\
\hline & 3.7 & $\mathrm{~K}-33$ & 4 & Single detection \\
\hline Gross Alpha & 200 & $\mathrm{~K}-21$ & 3 & Not consistent between rounds \\
\hline & 100 & $\mathrm{~K}-34$ & 4 & Not consistent between rounds \\
\hline Potassium-40 & 210 & $\mathrm{~K}-13$ & 3 & Single detection \\
\hline & 87.2 & $\mathrm{~K}-13$ & 4 & Not consistent between rounds \\
\hline Radium-226 & 22 & $\mathrm{~K}-20$ & 4 & Result from split sample analysis \\
\hline & 17 & $\mathrm{~K} \cdot 13$ & 3 & Single detection \\
\hline Strontium-90 & 100 & $\mathrm{~K}-21$ & 3 & Not consistent between rounds \\
\hline Thorium-228 & 10 & $\mathrm{~K}-37$ & 4 & Single detection \\
\hline Zinc-65 & 9.9 & $\mathrm{~K}-13$ & 4 & Single detection \\
\hline
\end{tabular}

Semi-Volitales (ug/I)

\begin{tabular}{|l|c|l|c|l|}
\hline Analyte & Value & Well & Round & Logic behind rejection \\
\hline Di-n-butylphthalat & $2 \mathrm{JB}$ & K-37 & 1 & Result from split sample analysis \\
\hline & $0.6 \mathrm{BJ}$ & $\mathrm{K}-31$ & 3 & Result from split sample analysis \\
\hline Diethylphthalate & $2 \mathrm{~J}$ & $\mathrm{~K}-31$ & 3 & Single detection \\
\hline
\end{tabular}


DOE/RL-93-79, Rev. 0

Table A-2 100-KR-4 Rejected Near-River Maximum Concentrations and Logic (page 2 of 3)

Unfiltered Inorganics ( $\mathrm{ug} / \mathrm{L}$ )

\begin{tabular}{|c|c|c|c|c|}
\hline Analyte & Value & Well & Round & Logic behind rejection \\
\hline \multirow[t]{6}{*}{ Aluminum } & 48900 & $\mathrm{~K}-21$ & 3 & Bad analysis \\
\hline & 1590 & $\mathrm{~K}-32 \mathrm{~A}$ & 1 & Not consistent between rounds \\
\hline & 1000 & $\mathrm{~K}-21$ & 1 & Not consistent between rounds \\
\hline & 531 & $\mathrm{~K}-20$ & 3 & Not consistent between rounds \\
\hline & $136 \mathrm{~B}$ & K.33 & 1 & Well not equilibrated \\
\hline & $74.4 \mathrm{~B}$ & $\mathrm{~K}-32 \mathrm{~A}$ & 4 & Not consistent between rounds \\
\hline \multirow[t]{3}{*}{ Antimony } & $43.6 \mathrm{~B}$ & $\mathrm{~K}-21$ & 3 & Bad analysis \\
\hline & $20.7 \mathrm{~B}$ & $K-18$ & 3 & Single detection \\
\hline & $19.1 \mathrm{~B}$ & $\mathrm{~K}-34$ & 3 & Single defection \\
\hline \multirow[t]{2}{*}{ Arsenic } & $18.5 \mathrm{NR}$ & $\mathrm{K}-34$ & 2 & Not consistent between rounds \\
\hline & $7.8 \mathrm{~B}$ & $\mathrm{~K}-21$ & 3 & Bad analysis \\
\hline Barium & 794 & K.21 & 3 & Bad analysis $^{\circ}$ \\
\hline \multirow[t]{7}{*}{ Beryllium } & $3.2 \mathrm{~B}$ & K-22 & 2 & Single detection \\
\hline & $2.7 \mathrm{~B}$ & $\mathrm{~K}-18$ & 2 & Single defection \\
\hline & $2.6 \mathrm{~B}$ & K-21 & 3 & Bad analysis \\
\hline & $1.6 \mathrm{~B}$ & K-20 & 2 & Single defection \\
\hline & $1.1 \mathrm{~B}$ & K-27 & 2 & Single detection \\
\hline & $1.1 \mathrm{~B}$ & K.31 & 2 & Single detection \\
\hline & $1.1 \mathrm{~B}$ & $\mathrm{~K}-21$ & 2 & Single detection \\
\hline \multirow[t]{2}{*}{ Cadium } & $30.3 \mathrm{JN}^{*}$ & $\mathrm{~K}-20$ & 4 & Not consistent between rounds \\
\hline & $5 \mathrm{RN}^{*}$ & $\mathrm{~K} \cdot 20$ & 4 & Not consistent between rounds \\
\hline Caicium & 327000 & K-21 & 3 & Bad analysis \\
\hline Chromium & 2040 & $\mathrm{~K}-21$ & 3 & Bad analysis \\
\hline \multirow[t]{2}{*}{ Cobalt } & 74.2 & $\mathrm{~K}-21$ & 3 & Bad analysis \\
\hline & $2 \mathrm{~B}$ & $\mathrm{~K}-21$ & 1 & Single detection \\
\hline \multirow[t]{8}{*}{ Copper } & 195 & $\mathrm{~K}-21$ & 3 & Bad analysis \\
\hline & $13.7 \mathrm{~B}$ & K.20 & 3 & Single detection \\
\hline & 9.38 & $\mathrm{~K}-31$ & 3 & Single detection \\
\hline & 78 & $\mathrm{~K}-32 \mathrm{~A}$ & 3 & Single detection \\
\hline & $5.6 \mathrm{~B}$ & $K \cdot 13$ & 2 & Single detection \\
\hline & $3.5 \mathrm{~B}$ & $\mathrm{~K}-18$ & 3 & Single detection \\
\hline & $3.2 \mathrm{~B}$ & $\mathrm{~K}-22$ & 3 & Single detection \\
\hline & $1.9 \mathrm{~B}$ & $\mathrm{~K}-21$ & 1 & Not consistent between rounds \\
\hline \multirow[t]{4}{*}{ Iron } & 96700 & $\mathrm{~K}-21$ & 3 & Bad analysis \\
\hline & 2920 & $\mathrm{~K} \cdot 32 \mathrm{~A}$ & 1 & Well not equilibrated \\
\hline & 2050 & $\mathrm{~K}-21$ & 1 & Not consistent between rounds \\
\hline & 1760 & $\mathrm{~K}-20$ & 3 & Not consistent between rounds \\
\hline Lead & 91.9 & K-21 & 3 & Bad analysis \\
\hline Magnesium & 35900 & $\mathrm{~K}-21$ & 3 & Bad analysis \\
\hline \multirow[t]{2}{*}{ Manganese } & 5390 & $\mathrm{~K}-21$ & 3 & Bad analysis \\
\hline & 183 & $\mathrm{~K}-34$ & 1 & Not consistent between rounds \\
\hline \multirow[t]{2}{*}{ Mercury } & $0.14 \mathrm{~B}$ & $\mathrm{~K}-18$ & 1 & Single detection \\
\hline & $0.14 \mathrm{~B}$ & $\mathrm{~K}-22$ & 1 & Single detection \\
\hline \multirow[t]{4}{*}{ Nickel } & 953 & $\mathrm{~K}-21$ & 3 & Bad analysis \\
\hline & 69.4 & $K-32 A$ & 1 & Well not equilibrated \\
\hline & 57.9 & $\mathrm{~K}-20$ & 3 & Single detection \\
\hline & 28.78 & $\mathrm{~K}-21$ & 1 & Not consistent between rounds \\
\hline
\end{tabular}

AT- $2 b$ 
DOE/RL-93-79, Rev. 0

Table A-2 100-KR-4 Rejected Near-River Maximum Concentrations and Logic (page 3 of 3)

Unfikered Inorganics (ug/L)

\begin{tabular}{|l|c|l|c|l|l|}
\hline Analyte & Value & Well & Round & Logic behind rejection \\
\hline Selenlum & 16.5 WNR & K-13 & 2 & Single detection \\
\hline & $16.5 \mathrm{NR}$ & $\mathrm{K}-37$ & 2 & Single detection \\
\hline & $9.4 \mathrm{JSN}$ & $\mathrm{K}-20$ & 4 & Not consistent between rounds \\
\hline & $4 \mathrm{BNS}$ & $\mathrm{K}-20$ & 3 & Not consistent between rounds \\
\hline & $2.7 \mathrm{BW}$ & $\mathrm{K}-33$ & 4 & Single detection \\
\hline & $2.7 \mathrm{BW}$ & $\mathrm{K}-13$ & 4 & Single detection \\
\hline & $2.6 \mathrm{WJ}$ & $\mathrm{K}-22$ & 2 & Result from split sample analysis \\
\hline & $2 \mathrm{RN}$ & $\mathrm{K}-20$ & 4 & Not consistent between rounds \\
\hline & 117 & $\mathrm{~K}-21$ & 3 & Bad analysis \\
\hline Vanadlum & $29.4 \mathrm{~B}$ & $\mathrm{~K}-33$ & 4 & Single detection \\
\hline
\end{tabular}

Wet Chemistry and Anions (mg/L)

\begin{tabular}{|l|c|l|c|l|}
\hline Analyte & Value & Well & Round & Logic behind rejection \\
\hline Alkalinity & 171 & $\mathrm{~K}-21$ & 3 & Not consistent between rounds \\
\hline Ammonia & $0.3 \mathrm{~J}$ & $\mathrm{~K}-33$ & 1 & Single detection \\
\hline & 0.22 & $\mathrm{~K}-18$ & 1 & Single detection \\
\hline & $0.09 \mathrm{~J}$ & $\mathrm{~K}-37$ & 2 & Single detection \\
\hline & $0.08 \mathrm{~J}$ & $\mathrm{~K}-32 \mathrm{~A}$ & 1 & Single detection \\
\hline & $0.07 \mathrm{~J}$ & $\mathrm{~K}-34$ & 1 & Single detection \\
\hline & 0.05 & $\mathrm{~K}-13$ & 1 & Single detection \\
\hline & 0.05 & $\mathrm{~K}-21$ & 1 & Single detection \\
\hline Chloride & 225 & $\mathrm{~K}-18$ & 4 & Not consistent between rounds \\
\hline & 25.8 & $\mathrm{~K}-22$ & 2 & Result from split sample analysis \\
\hline Phosphate & 0.4 & $\mathrm{~K}-13$ & 1 & Not consistent between rounds \\
\hline & $0.4 \mathrm{R}$ & $\mathrm{K}-20$ & 4 & Result from split sample analysis \\
\hline & $0.25 \mathrm{~J}$ & $\mathrm{~K}-31$ & 4 & Single detection \\
\hline Sulfate & 4100 & $\mathrm{~K}-22$ & 2 & Result from split sample analysis \\
\hline Sulfides & 1 & $\mathrm{~K}-13$ & 1 & Not consistent between rounds \\
\hline & $1 \mathrm{R}$ & $\mathrm{K}-20$ & 4 & Result from split sample analysis \\
\hline & $1 \mathrm{R}$ & $\mathrm{K}-13$ & 2 & Holding time exceeded \\
\hline & $1 \mathrm{R}$ & $\mathrm{K}-32 \mathrm{~A}$ & 2 & Holding time exceeded \\
\hline
\end{tabular}


DOE/RL-93-79, Rev. 0

\section{DISTRIBUTION}

Number of Copies

Qnsite

31

U.S. Department of Energy. Richland Operations

J. K. Erickson (30)

A5-19

Public Reading Room

A $1-65$

1

Pacific Northwest Laboratory

Hanford Technical Library

P8-55

29

Westinghouse Hanford Company

L. D. Arnold

B2-35

A. D. Krug (12)

H6-02

EPIC (7)

H6-08

ERC (G. Fitzgibbon)

H6-07

ERE (L. Hermann) (2)

H6-07

ERE Project File

H6-08

ER Program Office

H6-27

IRA (3)

H4-17

Resource Center

N3-05 

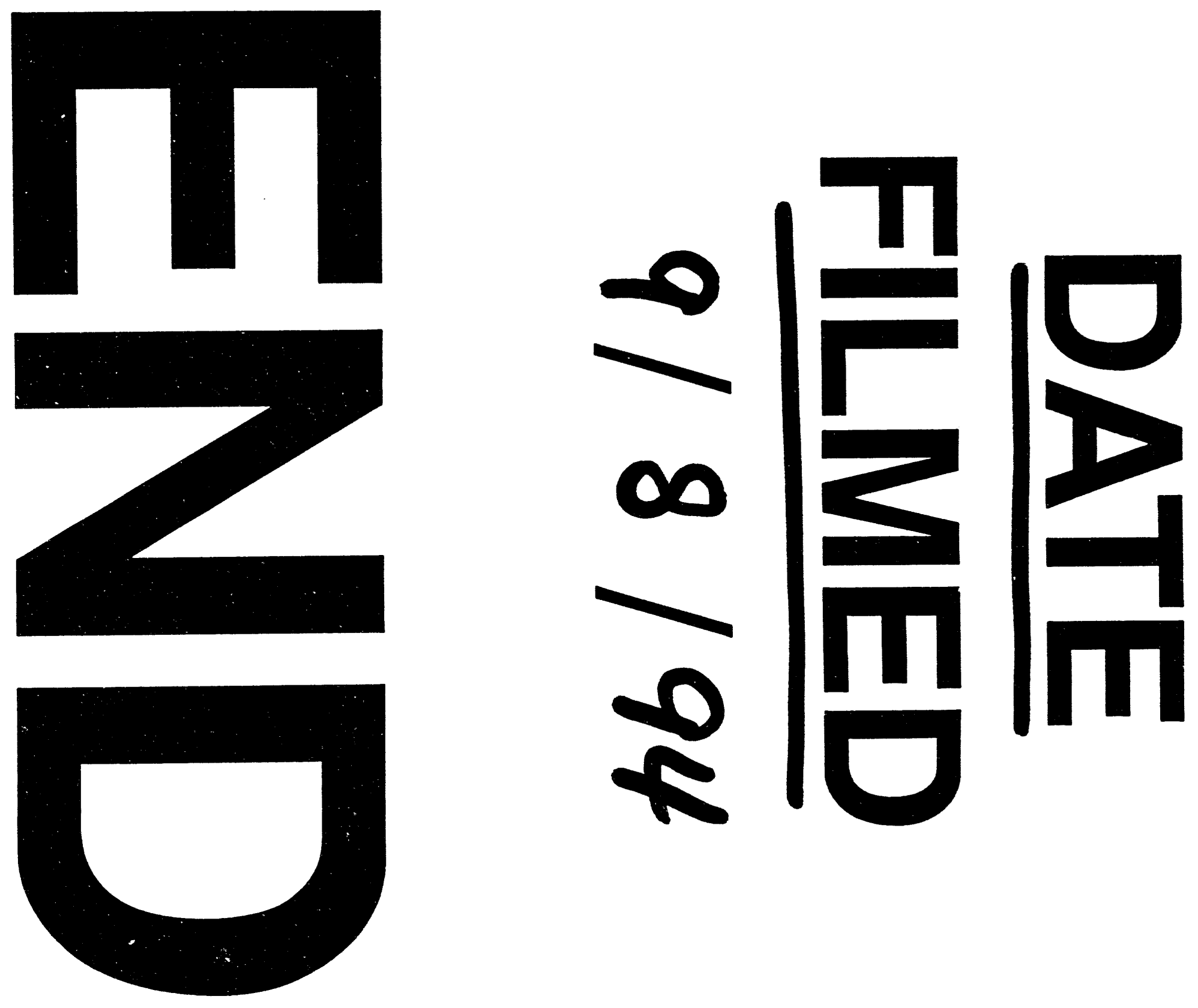

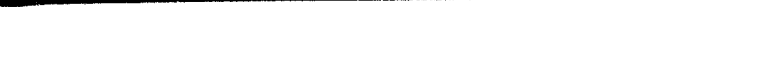

.

$$
-
$$

